\title{
ANÁLISIS DE LA CONTRIBUCIÓN DE LOS SANITARIOS SECOS AL SANEAMIENTO BÁSICO RURAL. \\ CASO: VEREDA CHORRILLOS.
}

\author{
PRESENTADO POR: \\ ANA KARINA MONTES \\ PONTIFICIA UNIVERSIDAD JAVERIANA \\ FACULTAD DE ESTUDIOS AMBIENTALES Y RURALES \\ MAESTRIA EN GESTION AMBIENTAL
}

DIRECTOR:

GABRIEL JOHN TOBON QUINTERO

2009 
NOTA DE ACEPTACIÓN

EVALUADOR 1

EVALUADOR 2 
TABLA DE CONTENIDO

1. INTRODUCCIÓN 5

2. PREGUNTA DE INVESTIGACIÓN 6

3. DESCRIPCIÓN DEL PROBLEMA 6

4. JUSTIFICACIÓN 9

5. ESTADO DEL ARTE 11

5.1. Sistemas Técnicos Convencionales 11

5.2. Sistema Técnico Alternativo 17

6. EXPERIENCIAS EN EL ÁMBITO MUNDIAL 21

7. EXPERIENCIAS EN COLOMBIA 35

8. EXPERIENCIAS DISTRITALES 38

9. MARCO CONCEPTUAL 41

10. AREA DE INVESTIGACIÓN 51

11. GENERALIDADES 53

12. OBJETIVOS 55

13. METODOLOGÍA 55

13.1. Enfoque 56

13.2. Estrategia De Investigación 58 
TABLA DE ANEXOS

ANEXO 1

PREGUNTAS GUÍAS DE LA ENTREVISTA GRUPO FOCAL

\section{ANEXO 2}

ENTREVISTA A INFORMANTES CLAVES

ANEXO 3

MATRIZ DE ANALISIS DE DATOS CUALITATIVOS

ANEXO FOTOGRÁFICO 1

PROBLEMÁTICAS AMBIENTALES

ANEXO FOTOGRÁFICO 2

TRABAJO CON GRUPO FOCAL

ANEXO FOTOGRAFICO 3

SANITARIOS SECOS VEREDA CHORRILLOS

\section{ANEXOS FOTOGRÁFICOS 4}




\section{INTRODUCCIÓN}

Esta investigación nace como respuesta a falencias en sistemas viables de saneamiento básico en poblaciones de escasos recursos, en lugares donde la infraestructura y los medios físicos, no permiten la adecuación de sistemas convencionales de alcantarillado. El uso práctico de la misma, se inicia a partir del análisis sobre el uso e implementación de sanitarios secos, basado en un trabajo de campo propuesto como piloto en la vereda Chorrillos, por parte de La Secretaria Distrital De Salud, a través del Hospital de Suba, ubicado en el Noroccidente de la Capital, Bogotá-Cundinamarca.

Los sanitarios secos son una alternativa, enfocada principalmente a resolver la problemática de manejo sanitario de excretas, implementando en una comunidad vulnerable un sistema apropiado, accesible, manejable y rentable. Que aporta soluciones ambientales, sanitarias, mejorando la calidad de vida de la población en todos sus aspectos.

La investigación cualitativa se basó en un estudio de caso y observación participante, usando instrumentos como entrevistas a informantes claves, trabajo con grupo focal, y trabajo de campo. El resultado es una matriz de análisis de entrevistas cualitativas, que permiten hacer una aproximación a los cambios generados gracias al uso de esta alternativa; las problemáticas socio ambientales de la zona, ventajas y desventajas de pozos sépticos (tradicionales), ventajas y desventajas de sanitarios secos, contribución real de sanitarios secos, adaptabilidad al núcleo social básico (familia), e impactos económicos primarios.

La difícil situación socio cultural, económica, y ambiental de la vereda, permite que este tipo de investigaciones se desarrollen de forma natural. El uso de este sistema garantiza, que si bien puede ser usado o implementado bajo situaciones de carácter 
extremo, como las vividas en Chorrillos, su importancia ambiental termina transformándola en una opción de saneamiento que a largo plazo podrá usarse en todas las zonas y condiciones en las que pueda y deba ser aplicada, tanto rurales como urbanas.

\section{PREGUNTA DE INVESTIGACIÓN}

¿Cuál es la contribución de los sanitarios secos al saneamiento básico en zonas rurales?

\section{DESCRIPCIÓN DEL PROBLEMA}

La Vereda Chorrillos ubicada en la localidad de Suba se encuentra fuera del perímetro urbano, las viviendas e instituciones ubicadas allí no cuentan con el servicio de acueducto y alcantarillado del Distrito Capital. Las políticas distritales no tienen como eje fundamental el mejoramiento y desarrollo de la ruralidad, debido a una corta visión sobre la rentabilidad de los sectores que no se incluyen en el perímetro urbano; sobre esta premisa reposa el descuido sanitario de una vereda como la de Chorrillos, sumada a sus condiciones geomorfológicas, las cuales no permite la construcción y mantenimiento de un alcantarillado tradicional.

A partir de los diagnósticos socio- ambientales, locales y la caracterización de las familias de la vereda Chorrillos realizada por el Hospital de Suba entre el $2006-2007^{1}$ se evidencia un escaso acceso a los servicios de agua potable, manejo de aguas servidas, a lo que se suma el bajo nivel de educación y desconocimiento de los principios higiénico-sanitario, contribuyendo a profundizar la baja calidad de vida entre

\footnotetext{
${ }^{1}$ Diagnostico socio ambiental, perteneciente al plan integral de entornos saludables.2006-2007
} 
las familias que habitan en la vereda, configurándose como un cuadro de alto riesgo para la salud de toda la población, especialmente para los 200 habitantes en edad infantil y personas mayores.

La ausencia de servicios básicos domiciliarios, genera graves problemas de contaminación del suelo y del agua subterránea, puesto que los habitantes se ven obligados a verter las aguas residuales sin ninguna clase de tratamiento a los espacios públicos por donde pasan los vallados de flujo no continuo hacia el río Bogotá, generando malos olores, y proliferación de vectores (ratas, zancudos, mosquitos, moscas). Adicionalmente, en temporada de invierno el caudal aumenta generando rebosamiento en pozos sépticos dando lugar a inundaciones de aguas negras en el interior de las viviendas.

Otro de los efectos sanitarios perjudiciales para la comunidad tiene que ver con el modo de extracción de agua para el consumo humano. Ésta, tiene como única opción de abastecimiento, nacimientos naturales (aljibes o pozo profundo) que se han acondicionado como fuentes de carácter comunal o familiar, sin guardar la debida distancia de los pozos sépticos o los vallados. Debido a la proximidad resulta natural que el agua de los aljibes destinada para el consumo humano resulte contaminada con bacterias del tipo de la E. Coli, presente en la materia fecal y causante de enfermedades diarreicas agudas (EDA). La mayoría de estos pozos no cuentan con recubrimiento interno, ni protección, lo cual pone en riesgo físico a los habitantes, en especial a los menores, proclives a caer y perecer de forma inmediata, debido a la profundidad de los mismos. A su vez el sistema de conducción se realiza mediante la unión de mangueras que presentan porosidad y fisuras, incrementando las posibilidades de contaminación del agua que se utiliza para consumo humano.

La anterior información se basa en estudios realizados entre los años 2005 a 2006, llevados a cabo por el Hospital De Suba (Línea de Saneamiento Básico Alternativo) donde se tiene un censo estimado de 90 pozos de agua ubicados en la vereda 
Chorrillos, de los cuales aproximadamente 60 corresponden a viviendas con población vulnerable y 30 pozos pertenecientes a instituciones tanto privadas como públicas, incluyendo las fincas o haciendas dedicadas a producción agropecuaria. La línea de intervención de saneamiento básico ha realizado inspecciones de vigilancia y control sanitario a 49 pozos de los 60 que surten agua a población vulnerable de la zona, encontrando que el $90 \%$ poseen concepto pendiente por la no aceptabilidad en los análisis de laboratorio: desde el análisis microbiológico por presentar Unidades Formadoras de Colonia -UFC- de E-Coli y Coliformes Totales y desde el análisis físico químico por no cumplir con los niveles permisibles de hierro, dureza, alcalinidad y cloro residual de acuerdo al Decreto 475 de 1998 del Ministerio de Salud, donde se definen las normas técnicas de calidad del agua potable. Sumado a esto se presume que los acuíferos que surten estos aljibes están expuestos a contaminación por filtración de aguas contaminadas de los pozos sépticos, y plaguicidas aplicados a los cultivos encontrados en la zona.

Finalmente, las problemáticas ambientales de la zona se resumen en tres grandes aspectos:

- CONTAMINACIÓN ATMOSFÉRICA: Esta se presenta en la vía SUBA COTA, y vías internas de la vereda, debido a la circulación de todo tipo de automotores, desde el tráfico pesado (volquetas, tracto mulas), transporte urbano intermunicipal, rutas escolares, vehículos particulares y motos ${ }^{2}$. Se suma el vertimiento de aguas grises y negras de forma inadecuada generando la proliferación de malos olores, perjudicando a la población de manera directa y aumentando la presencia de enfermedades respiratorias.

- CONTAMINACIÓN HíDRICA: la falta de sistemas adecuados para el manejo de aguas grises y negras, producidas por actividades domésticas,

\footnotetext{
${ }^{2}$ Diagnóstico barrial vereda chorrillos, atención primaria en salud con enfoque familiar y comunitario, Secretaria Distrital de Salud, 2007
} 
obliga a la mayoría de habitantes a ubicar estos desechos en los vallados que se encuentran paralelos a algunas vías, que a su vez alimentan algunos pozos de agua subterránea, generando un ciclo de enfermedades diarreicas agudas, especialmente en la población vulnerable. (Personas mayores, y niños) incrementando la problemática ambiental, ya que estos afluentes llegan a la sección del río Bogotá que corresponde a los colindes de la vereda. Adicionalmente a esto la presencia de residuos sólidos es una constante en los cuerpo de agua, debido a que la frecuencia de recolección de este tipo de desechos, a cargo de la empresa LIME$^{3}$, no es constante.

- CONTAMINACIÓN DE SUELOS: Se presenta alta concentración de carga orgánica generada por la infiltración de las excretas proveniente de los pozos sépticos ubicados en las viviendas de los tres sectores, acompañadas de las descargas de agroquímicos generadas por los cultivos, especialmente de flores, y las prácticas inadecuadas de las producciones pecuarias. El resultado final de la sumatoria de factores, se manifiesta en la calidad de agua que los habitantes consumen actualmente, y como ya he dicho obtiene su fuente de la perforación de pozos o aljibes sin el debido tratamiento sanitario.

\section{JUSTIFICACIÓN}

Esta investigación se realiza a partir de un análisis de alternativas específicamente los sanitarios secos para el saneamiento básico en zonas rurales, el caso de los sanitarios secos, aportando datos que demuestran la sostenibilidad de estos sistemas para familias que no cuentan con acceso a servicios públicos básicos, además de constituirse como un estilo de vida amiga con el ambiente.

Este trabajo aporta al sector rural una alternativa distinta a la que actualmente se viene implementando con los pozos sépticos, causantes de graves problemáticas de

\footnotetext{
${ }^{3}$ Ver anexo fotográfico 1.
} 
salud y deterioro ambiental, debido a la contaminación que despliegan sobre los bienes y servicios ambientales. Se busca con la implementación de los sanitarios secos, que la población tenga alternativas de manejo sencillo, económico y ambientalmente viables, demostrado en diversas experiencias mundiales, por medio de practica y resultados.

El sanitario seco es un sistema que permite la separación de excreta y la orina por medio de una taza separadora, con el fin de hacer un manejo adecuado de los biosolidos, transformándolo en material aprovechable como el abono orgánico. Desde el punto de vista teórico los sanitarios secos contribuyen a la reincorporación de nutrientes a los ciclos biológicos y reivindica la relación del hombre con la naturaleza, además de mitigar y/o prevenir los problemas de carácter ambiental.

Finalmente esta investigación busca aportar elementos teórico-prácticos para dimensionar los proyecto pilotos que se realizan bajo esta alternativa, incluyéndose en programas que hagan parte de los planes de desarrollo local, contemplando la posibilidad de incorporarlas en la Política Ambiental Distrital, buscando elevarlos a directrices ambientales de carácter nacional. 


\section{ESTADO DEL ARTE}

Una de las principales causas de morbilidad y mortalidad en los países de América Latina es la baja cobertura de los servicios de disposición de aguas servidas y excretas; solo $49 \%$ de la población cuenta con servicio de alcantarillado, el 38\% dispone sus excretas por medio de letrinas y el 13\% (60 millones de latinoamericanos) defecan al aire libre. Esto ha motivado diferentes investigaciones que han tratado de buscar soluciones a la disposición adecuada de las excretas humanas. A continuación se hará una breve descripción de los sistemas técnicos convencionales y los sistemas técnicos alternativos como respuesta al manejo y evacuación de excretas en zonas rurales.

\subsection{Sistemas Técnicos Convencionales}

\section{Alcantarillado}

El sistema de alcantarillado es el medio de conducción más reconocido para la evacuación de excretas, a través de flujos de agua que arrastra los desechos (aguas negras y grises) para su debido tratamiento.

El retrete dotado de cisterna, básico en la vida moderna, aparece para el uso de la realeza minoica hace cuatro mil años. En el año 1596, se instaló para Isabel de Inglaterra una versión ideada por un cortesano de Bath, sir John Harrington, ahijado de la reina. Este caballero se sirvió del aparato, que él denominaba "retrete perfeccionado".

El diseño de Harrington era bastante complejo en muchos aspectos. Incluía una alta torre de agua que remataba la estructura principal, un grifo accionado a mano que permitía al agua fluir en un depósito, y una válvula que vaciaba los detritos en un albañal cercano. 
El siguiente retrete evacuador de aspecto distinguido apareció en el año 1775, patentado por Alexander Cumming, un matemático y relojero británico. Difería del modelo anterior en un aspecto significativo, ya que el "water de Harrington", como otros ideados en la época, comunicaba directamente con un albañal, y lo separaba del hediondo contenido de éste una simple trampilla suelta. El tubo de comunicación, por su parte, no contenía agua que impidiera el paso de los hedores. La propia reina Isabel criticó el diseño y se quejó ásperamente de que los constantes efluvios del albañal no le permitían utilizar el invento de su ahijado.

En el modelo perfeccionado de Cumming, la tubería situada inmediatamente debajo de la taza se curvaba hacia atrás a fin de "retener en todo momento una cantidad de agua para atajar los olores procedentes de abajo", como rezaba la solicitud de patente de Cumming, El inventor dio a este dispositivo el nombre de "trampa de mal olor", y pasó a convertirse en parte integrante de todos los futuros modelos de baños. El moderno lavado de cisterna había sido inventado, pero pasarían más de 100 años antes de que sustituyera al orinal y las letrinas exteriores, para convertirse en una instalación comúnmente en los cuartos de baño europeos y norteamericanos. ${ }^{4}$

Existen tres tipos tradicionales de sistemas de transporte por agua:

o Uno de los más antiguos y desarrollado en 1833, París, es el sistema combinado ("Tout-a l'égout"). En este sistema combinado, los sistemas de alcantarillado tienen que ser suficientemente grandes para recibir todos los flujos pluviales o la mayoría de ellos. Son costosos y durante el tiempo seco pueden acumular sedimentos. Los colectores se instalan a grandes profundidades.

\footnotetext{
${ }^{4}$ Panati, Charles. Las cosas nuestras de cada día. Circulo de lectores, Barcelona.
} 
o El sistema parcialmente separado, en el que el agua pluvial de las propiedades privadas, patios y techos, se descarga en el sistema de alcantarillado sanitario. Este sistema que fue adoptado en las ciudades británicas; se propuso para Río de Janeiro, en 1857.

o El sistema separado, en el que se excluye por completo el agua pluvial. Este sistema fue creado por George Waring Jr. en los Estados Unidos, en 1879, para la ciudad de Memphis, Tennessee. Escasos cambios y mejoras se han introducido desde entonces. ${ }^{5}$

Las características de estos sistemas se basan en diseños a partir de las conexiones domiciliarias, y el consumo per cápita de la población, lo cual permite dimensionar la tubería, la profundidad de excavación donde se controla la sedimentación en las tuberías por la fuerza de arrastre a través del criterio de velocidad mínima nominal. Luego de este recorrido de unión de aguas negras, debe llegar a una planta de tratamiento de aguas residuales diseñada a partir del caudal que entra a la misma, donde se realizan los tratamientos necesarios para bajar la carga contaminante al agua que será descargada al fluente receptor más cercano.

La construcción de un sistema de alcantarillado parece ser la solución más atractiva para los usuarios de pozos negros, y de fosas sépticas mal construidas, mal mantenidas o contaminadoras, sin embargo el alcantarillado es una infraestructura de alto costo que requiere de importantes inversiones públicas, lo que significa que en muchos lugares su construcción es postergada por existir otras prioridades de presupuesto. En otras zonas, las razones de orden técnico dificultan o imposibilitan esta opción: escasez de agua potable, topografía, costo desproporcionado por baja densidad poblacional o grandes distancias, hasta un curso de agua receptor. ${ }^{6}$

\footnotetext{
${ }^{5}$ http://www.col.ops-oms.org/saludambiente/Acueductos/condo2residuales.asp
} 
En la mayoría de los casos lo sistemas convencionales de alcantarillado contribuyen a mejorar las condiciones de salud aportando eficiencia en el descarte de las excretas, asumiendo un costo periódico obligatorio. Es evidente que este tipo de sistemas no constituyen una opción realista para las poblaciones de escasos recursos de los países en vías de desarrollo. ${ }^{7}$

\section{Pozo séptico}

Uno de los sistemas utilizados con mayor frecuencia para la eliminación de excretas en zonas rurales, pueblos costeros, ciudades pequeñas, poblaciones marginales o sin acceso a la red de alcantarillado en Latinoamérica, son los pozos sépticos o también llamados letrinas. Estos consisten en una simple fosa excavada a mano, que es reemplazada una vez se llena. Revistiéndose con losa de vigas, tablas o concreto, adecuando un asiento generalmente de madera y una caseta de cualquier material y calidad, para asegurar la privacidad de los usuarios.

Este sistema está al alcance de todos por su simple construcción, uso, mantenimiento y bajo costo. ${ }^{8}$ Sin embargo, las graves desventajas de los pozos sépticos son: olores desagradables, precarios estados sanitarios en la tenencia del sanitario, proliferación de moscas, cucarachas y otros insectos, vectores de enfermedades infecciosas, desbordamiento en período de lluvias, contaminación directa del suelo y aguas subterráneas que sirven para el abastecimiento de agua a través de norias o pozos instalados a poca distancia del pozo séptico, como es el caso de la vereda

\footnotetext{
${ }^{6}$ Montecinos. Vicente, Unidades sanitarias secas: Una solución económica y ambientalmente sustentable para el saneamiento básico, Corporación CETAL 2002-2009

${ }^{7}$ LEWIS, W.J. Foster, S.S.D. Drasar B.S. Análisis de la contaminación de las aguas subterráneas por sistemas de saneamiento básico. 1988.

${ }^{8}$ Montecinos. Vicente, Unidades sanitarias secas: Una solución económica y ambientalmente sustentable para el saneamiento básico, Corporación CETAL 2002-2009
} 
Chorrillos; incrementado los problemas ambientales y edáficos importantes como la pérdida de la capacidad de infiltración del suelo, y el rebosamiento de los efluentes. Como vemos, la efectividad de la mayoría de los sistemas sanitarios de disposición local depende, fundamentalmente, de la capacidad del suelo y las características hidráulicas del mismo.

De acuerdo al análisis de contaminación de aguas subterráneas por sistemas de saneamiento básico de Lewis, Foster y Drasal (1988), hacen referencia a que los países en desarrollo, poseen pocos estudios sobre aguas subterráneas contaminadas por el uso de sistemas sanitarios de disposición local, sin embargo los valores aproximados sobre la carga común del efluente son:

De 7-13 litros / día, que es el promedio de los fluidos fecales de 5-10 personas. En los lugares en donde se utiliza agua para la higiene anal, la carga puede aumentar hasta 17-33 Lts/día. En las letrinas con taza de descarga manual es de 45-95 Lts/día. Esto incluye los fluidos fecales (1.3 litros), el agua destinada a la higiene (2 litros) y el agua de descarga (6 litros) para 5-10 personas. ${ }^{9}$

Recodemos que, las excretas humanas pueden contener hasta cuatro tipos de organismos patógenos: huevos de helmintos, protozoarios, bacterias y virus. Estos organismos generalmente son excretados en grandes cantidades, dependiendo de la edad y el estado de salud del individuo. La materia fecal contiene en promedio de $10^{9}$ bacterias por gramo (no necesariamente patogénicos) y, en el caso de excretas de individuos infectados, hasta $10^{6}$ virus por gramo. Estas partículas o virus pueden producir enfermedades en las personas que los ingieren con el agua. ${ }^{10}$

Teniendo en cuenta la anterior información, es de vital importancia mencionar algunos de los factores que influyen en el trasporte de bacterias y virus a través del

\footnotetext{
${ }^{9}$ LEWIS, W.J. Foster, S.S.D. Drasar B.S. Análisis de la contaminación de las aguas subterráneas por sistemas de saneamiento básico. 1988.

${ }^{10}$ National Academy of Sciences, 1977 en Lewis, et al 1988
} 
suelo según Gerba et al 1975, donde se subraya que en suelos de composición arcillosa las bacterias y virus encuentran condiciones apropiadas para su absorción, igualmente en suelo donde se presente alto contenido de materia orgánica. Respecto a la carga hidráulica los microorganismos penetran con mayor profundidad al aumentar la velocidad del flujo. La carga hidráulica se eleva naturalmente durante periodos de recarga de las aguas subterráneas por la infiltración de las lluvias. Asociado a este factor los microorganismos que son retenidos próximos a la superficie del suelo permiten una adecuada desabsorción luego de una fuerte lluvia. Otros factores primordiales son la humedad y la temperatura, donde favorecen a alcanzar periodo de supervivencia de 175 días o más.

Así mismo el período de supervivencia de las bacterias se extiende cuando en los suelos existen nutrientes de fácil acceso, como ocurre con los suelos que reciben efluentes sanitarios. Los coliformes fecales aparentemente sólo sobreviven 70 días con las condiciones ambientales, con una reducción del 90\%, pasado los 15-20 días. Sin embargo, en un medio húmedo y de baja temperatura, algunos coliformes fecales pueden sobrevivir muchos meses.

Son evidentes los efectos en la salud humana debido a la contaminación del agua y los alimentos como se menciona en el estudio del Departamento de Microbiología de la Universidad de Barcelona, sobre virus emergentes humanos, y que según datos de la Organización Mundial de la Salud, las enfermedades infecciosas representan un gran riesgo y son la principal causa de muerte en niños y adultos jóvenes, donde aproximadamente 2 millones de personas mueren cada año, en su mayoría niños menores de 5 años. El espectro de enfermedades se está ampliando y la incidencia de muchas de éstas, se encuentran relacionadas directamente con el agua. Desde 1970 varias especies de microorganismos presentes en heces humanas o animales se han confirmado como patógenos; como el caso del rotavirus, virus de la hepatitis $\mathrm{E}$ y norovirus, además pueden causar distintas enfermedades como meningitis, algunos 
tipos de parálisis, enfermedades respiratorias, diarreas y vómitos, miocarditis, anomalías congénitas de corazón, hepatitis, infecciones oculares y según datos recientes, podrían estar también relacionados con diversos tipos de cáncer ${ }^{11}$

Además se ha detectado que para una población de 300.000 habitantes pueden liberarse al ambiente cantidades de $10^{9}$ partículas víricas en 24 horas en aguas residuales tratadas. ${ }^{12}$

Finalmente se sabe que existe una alta prevalencencia de virus en el ambiente, lo que causa un importante impacto en la salud pública a través de la transmisión de enfermedades por el agua y los alimentos. Se hace necesario volcar la mirada a esta problemática y plantear soluciones reales que se ajusten a las necesidades de cada territorio.

\subsection{Sistema Técnico Alternativo}

\section{Sanitarios secos}

Los sanitarios secos o también llamados sanitarios ecológicos plantean una propuesta simple y que para algunos resulta descabellada. Es un sistema de eliminación de excretas que no necesita agua y con el cual se puede obtener un subproducto el abono orgánico. Como se menciona en algunos estudios consultados y experiencias del primer curso internacional de saneamiento ecológico los sanitarios ecológicos secos familiares y comunitarios constituyen una tecnología apropiada para la disposición, aislamiento, almacenamiento y tratamiento de la excreta. El enfoque de saneamiento ecológico que le dan algunos autores es convertir la excreta humana en

\footnotetext{
${ }^{11}$ BOFIA-MALS, Silvia. CLEMENTE-Casares, Pilar. ALBIÑANA-Gimenez, Nestor. MALUQUER DE MONTES, Carlos. HUNDESAGOFA, Ayalkibet. GIRNES Llop, Rosina. Efectos sobre la salud de la contaminación del agua y alimentos por virus emergentes humanos Universidad De Barcelona. 2005 12 Ibíd.
} 
material seguro; prevenir la contaminación en vez de controlarla después de contaminar, y usar en la agricultura los productos seguros de excreta humana saneada. Este enfoque puede llamarse sanear y reciclar. ${ }^{13}$

El diseño surge como una concepción de la prevención de las enfermedades y protección al ambiente no solo en áreas rurales sino también urbanas, constituye una barrera física primaria en la transmisión de parasitosis, ya que en las cámaras de aislamiento tiene lugar el proceso de desactivación y mortalidad de patógenos.

Los sanitarios ecológicos secos usados convenientemente, pueden reducir en el $36 \%$ la morbilidad por diarreas, porcentaje que puede incrementarse con el mejoramiento de los hábitos higiénico-sanitarios, relacionados con la eliminación y tratamiento de excreta (lavado de manos). En este sentido la mejora del entorno puede disminuir la morbilidad, mortalidad, gastos por ingreso y tratamientos en los diferentes niveles de atención. ${ }^{14}$

En las cámaras de aislamiento se da un proceso de biodegradación de las excretas, el sistema plantea el uso de dos cámaras alternas una activa (en uso) y otra en reposo donde se da lugar a los procesos de desactivación y mortalidad constante de organismos y patógenos. Estos dos momentos dependen de diversos factores: tipo de organismo, temperatura, $\mathrm{pH}$ y humedad, entre otros. ${ }^{15}$

Las cámaras de los sanitarios comunitarios funcionan como deshidratadores de la excreta a través de la instalación de captadores solares y ventilación, mantienen temperaturas de 50 a $70^{\circ} \mathrm{C}$, lo que garantiza la destrucción de huevos de helmintos e impide el desarrollo de larvas de mosca, por tanto, los captadores y la ventilación, producen un descenso en la humedad y las células, al carecer del agua necesaria para

\footnotetext{
${ }^{13}$ SAWYER, Tom, ANDERSON, Ingvar. HILLERS, Astrid. ESREY, Steven. Cerrando el ciclo: saneamiento ecológico para la seguridad alimentaría. Segunda edición. México 2006

${ }^{14}$ GUERRERO María Teresa. TAMISET, Jan. MARTINEZ Raúl. HERNÁNDEZ Yolanda. Diseño y construcción de sanitarios secos en áreas rurales. Universidad Autónoma de San Luis De Potosí. México. 2006 
su metabolismo, mueren por desecación. Los sanitarios ecológicos familiares pueden mantener temperaturas hasta de $30^{\circ} \mathrm{C}$. El almacenamiento de la excreta por un período mínimo de 3 meses produce la desactivación y extinción natural de patógenos excepto de helmintos. ${ }^{16}$

Las tazas tienen como función esencial separar la excreta de la orina para generar una descomposición aerobia, lo que afecta la supervivencia de las bacterias entéricas pues al separar excreta de orina, disminuye la humedad, factor que puede favorecer o afectar las condiciones para su desarrollo. El lavamanos tiene por finalidad promover el lavado de manos para cortar el ciclo ano-mano-boca y en la adición de mezcla secante, pretende promover el tratamiento primario de excreta con tierra, ceniza, cal o la mezcla de estos elementos por partes iguales. La práctica de cubrir la materia fecal con material secante, cumple la función de aislarla de moscas y cucarachas que prematuramente diseminan la excreta y trasladan mecánicamente en sus patas, trompas o tracto gastrointestinal a los agentes infecciosos. ${ }^{17}$

Posteriormente se busca que la excretas entre nuevamente al ciclo biológico no como un agente patógeno sino como un abono que puede aportar grandes nutrientes y contribuir a la recuperación de suelos o su aprovechamiento en cultivos agrícolas. Esta práctica se viene ejerciendo hace años en varios países como China los cuales compostan las excretas animales y de humanos. En Japón se introdujo esta práctica de reciclado de excreta y orina humanas desde el siglo XII. En Suecia, donde la desviación de orina ya se práctica, los agricultores recolectan la orina almacenada en tanques subterráneos, y la aplican a sus cultivos con maquinaria. ${ }^{18}$

Uno de los puntos más importantes que se deben mencionar sobre este sistema es la adaptabilidad de las familias a un método nuevo sin que se sientan vulnerables o

\footnotetext{
${ }^{16}$ Ibíd.

${ }^{17}$ Ibíd.

${ }^{18}$ SAWYER, Tom, ANDERSON, Ingvar. HILLERS, Astrid. ESREY, Steven. Cerrando el ciclo: saneamiento ecológico para la seguridad alimentaría. Segunda edición. México 2006
} 
socialmente rechazados por el uso de estas tecnologías. Es en este aspecto donde debemos concentrar el trabajo, implementado sanitarios secos de forma práctica, para que las familias comprendan la utilidad de este nuevo sistema, las ventajas, y el mantenimiento adecuado que se debe ejercer en ellas, debemos aclarar que uno de los factores importantes, es comprender que los hábitos higiénico sanitarios pueden proteger a las familias del ataque de enfermedades.

Se han propuestos varias metodologías donde se establecen principalmente dos momentos claves los cuales son la sensibilización y la capacitación. Una de ellas es la SARAR (seguridad a sí mismo, asociación con otros, reacción con ingenio, acciones planeadas y responsabilidad) el cual es un método participativo que busca cambiar la resistencia por la toma de decisiones. Esta como otras metodologías, busca vincular a la familia a ese nuevo sistema romper los paradigmas establecidos por la sociedad y buscar solución a un problema ambiental, de salubridad y en muchos casos social. ${ }^{19}$

Analizando las ventajas que trae este sistema, entre las cuales está el ahorro de agua potable, acceso a un sistema sanitario en muchos casos más digno o manejable, la posibilidad de incluir nutrientes a los suelos y bajar las tasas de contaminación de las aguas, me atrevería a afirmar que es vital que se promocione en regiones donde el alcantarillado no es viable o en comunidades necesitadas de este tipo de tecnologías, si bien es cierto en un principio pueden causar estupor y hasta rechazo, con el tiempo y de mano de una adecuada capacitación e implementación, se convierte en una de las opciones más amigables con el ambiente, en cuanto a la eliminación de excretas.

${ }^{19}$ Ibíd. 


\section{EXPERIENCIAS EN EL ÁMBITO MUNDIAL}

Experiencias a nivel mundial podemos encontrar de diversos tipos y en varios países, en la literatura se encuentran clasificados en dos los sistemas basados en la deshidratación y en la compostación. ${ }^{20}$

\section{Europa}

La primera patente para un inodoro de tierra, se registró en 1838 por Thomas Swinburne, aunque no tuvo auge en su momento un cuarto de siglo después Henry Moule empezó a experimentar enterrando sus heces en el jardín y después de 304 semana no había rastros del material enterrado, con lo cual dio inicio al diseño de su propio inodoro en el que se depositaba una cantidad determinada de tierra, que caía de una tolva ubicada detrás de la tazas sobre las heces frescas. ${ }^{21}$

Después de patentar su diseño elaboró modelos lujosos, para escuelas, barracas y hospitales, la publicidad de Moule recalcaba las ventajas de este sistema sanitario basado en el uso de la tierra y mencionaba las problemáticas de los sistemas que usaban agua.

En 1868 se reportó que se usaron 148 sanitarios de tierra en un campamento militar de Wimbledon, Londres. Dos mil soldados utilizaron 40 de dichos sanitarios, sin ninguna molestia por el olor. En 1860 un buen número de escuelas cambiaron los

\footnotetext{
${ }^{20}$ Ver anexos fotográficos 4 y 5.

${ }^{21}$ ESREY, Steven. GOUGH, Jean. RAPAPORT, Dave. SAWYER, Ron. SIMPSON-HEBERT, Mayling. VARGAS, Jorge. Saneamiento ecológico. Agencia Sueca de Cooperación Internacional para el Desarrollo/ Fundación Friedrich Ebert-México. México. 1999. 101pag.
} 
sanitarios de agua por los de tierra, ya que los consideraban más confiables y de mantenimiento más accesible.

En 1870 Moule y otros inclinaron sus observaciones hacia cómo podría usarse el calor para tratar los patógenos y quitar olores. Algunos diseños consistían en una bandeja para secado integrada a la parrilla de la chimenea. Otros diseñadores desarrollaron muebles con tolvas más grandes que podían servir hasta para mil sesiones, antes de ser rellenadas de tierra.

A principios de la década de 1980, el profesor Mats Wolgast del Karolinska Institutet, en Estocolmo, Suecia, desarrolló el sistema WM Ekologen, tipo ES. Al igual que el sistema vietnamita, se basa en un proceso de deshidratación, diseñado para desviar la orina, el depósito lleno se deja en la cámara por un período de seis meses, aproximadamente. Después de ese tiempo, el contenido puede procesarse, como tratamiento secundario, en un recipiente ventilado para composta; para que el papel higiénico se descomponga, o bien se incinere. Este sistema es de alta calidad y está diseñado para instalarse dentro del cuarto de sanitario en una casa moderna. Se utiliza tanto en zonas urbanas como rurales y en instituciones, lo mismo que en hogares privados. $^{22}$

En cuanto a los sistemas sanitarios basados en la compostación en Suecia se introdujeron hace más de cincuenta años en las casas de fin de semana, desde hace un buen tiempo el mercado ofrece diversos modelos que han sido utilizados en Estados Unidos y Australia.

Al Multrum como se suele llamar este sistema, no sólo llegan las heces, sino el papel higiénico y la orina, además de los residuos orgánicos provenientes de la cocina.

\footnotetext{
${ }^{22}$ Ibid.
} 
Debido a la pendiente con que cuenta el piso de la cámara del sanitario Multrum, el material fresco que cae resbala poco a poco, desde la parte donde se deposita, a la parte baja donde se va almacenando. El proceso de descomposición disminuye el volumen de la pila, reduciéndose 90\%, antes de usar el Multrum por primera vez, el usuario debe colocar una base en el piso de la cámara de composta. Esta base está conformada de una capa gruesa $(40 \mathrm{~cm})$ de turba y una capa de suelo rico en humus $(20 \mathrm{~cm})$; previamente hay que mezclarla con pasto cortado. El propósito de esta cama es absorber líquidos y proporcionar los microbios necesarios para la oxidación de la orina.

Poco a poco el material apilado se convierte en humus, la cantidad de humus que se produce varía de diez a treinta litros por persona al año. El número máximo de usuarios para un Clivus Multrum es de 8 a 10 personas, considerando un uso normal durante un año. Las familias lo retiran hasta después de cinco años, a partir de ese momento puede hacerlo una vez al año.

En Suecia se considera segura la utilización del humus directa como fertilizante o como acondicionador de suelo, ya que tiene un contenido bacteriano similar al de la tierra. Se cree actualmente que en el mundo operan 10,000 sanitarios Clivus Multrum.

\section{Asia}

El sanitario de doble cámara que se utiliza en Vietnam es un ejemplo clásico de un sistema sanitario ecológico con base en la deshidratación. Este sanitario es de uso cotidiano en el norte de Vietnam, y en los últimos veinte años en América Central, México y Suecia. En el norte de Vietnam una práctica común era fertilizar los campos arroz con excreta humana fresca, lo cual llevo en 1956 a una campaña de construcción de sanitarios secos, que permitía eliminar patógenos antes de utilizar las heces en el campo, acompañado de una fuerte educación sanitaria entre sus pobladores 
reduciendo la incidencia de enfermedades producidas por hábitos inadecuados de higiene. ${ }^{23}$

En los barrios Sanaa, al igual que en otras poblaciones de Yemen, las casas tradicionales tienen de cinco a nueve pisos, en las cuales habita una sola familia muy numerosa. En el último piso cuenta con uno o dos cuartos de baño secos, muy cerca de un pozo (un cañón vertical, largo y angosto), donde caen las excretas, debido a que Sanaa tiene un clima caliente y seco, las heces se secan rápidamente. Es un sistema tradicional que tiene siglos de usarse en las ciudades yemenitas. No hay malos olores ni criadero de moscas, tanto la orina como el agua que se utiliza para el aseo se evaporan, mientras que las heces se procesan en tres etapas: primero se deshidratan en el lugar mismo; segundo, se les someten a un proceso de desecado posterior con exposición directa a los rayos solares en los sanitarios públicos, para finalmente incinerarse. ${ }^{24}$ Este es un claro ejemplo del enfoque de sanitarios ecológicos aplicado en una zona urbana con edificios de varios pisos y recolección comunitaria de las heces deshidratadas. La recolección es efectuada por personal especializado.

Ladakh (India) es una región seca a gran altura en la zona occidental del Himalaya, a una altitud de 3,500 m sobre el nivel del mar. Las viviendas tradicionales cuentan con un sanitario dentro de la casa, en el piso superior. Debido a lo seco del clima, es posible deshidratar las heces sin separar la orina. En un cuarto pequeño, contiguo a la cocina/ sala, se coloca una capa gruesa de tierra traída del patio; un orificio en el piso permite el paso de la excreta a un cuarto pequeño en el piso inferior, cuyo acceso se logra sólo desde el exterior. La gente defeca sobre la capa de tierra del cuarto superior, después empuja los excrementos hacia el agujero, mezclados con tierra y orina. De vez en cuando se agregan las cenizas que salen de la cocina. Cuando hace falta, los 
miembros de la familia acarrean más tierra al cuarto. ${ }^{25}$ Durante los inviernos prolongados se apila una reserva de tierra en un rincón del baño, donde también se guarda un azadón o una pala. En la primavera y al final del verano se remueve el excremento descompuesto y se esparce sobre los campos. ${ }^{26}$

La forma de funcionamiento adecuado de este sistema se basa en agregar suficiente tierra para prevenir malos olores, evitando presencia de moscas debido a lo seco de la mezcla apilada de tierra y excremento. Desde hace siglos este sistema ha funcionado muy bien en las zonas rurales, aunque en años recientes se han presentado problemas en la parte céntrica del pueblo de Leh, donde las familias no pueden acceder fácilmente a la tierra.

En Kerla, India, el sistema sanitario vietnamita se adaptó en una población que utiliza agua para el aseo anal después de la defecación. La orina se separa, junto con el agua utilizada para el aseo anal, pero en este caso por medio de una cama de evapotranspiración anexa al sanitario. Antes de que el sanitario se use por primera vez, es necesario colocar paja en la cámara, lo que proporciona una base rica en carbón para recibir las heces y absorber la humedad. Después de cada uso se esparce un puñado de cenizas. De vez en cuando se agrega un poco de paja, hojarasca y pedazos de papel, lo que significa que está implícito un proceso de descomposición, más que uno de deshidratación. ${ }^{27}$

Esto lo confirma la reducción en volumen que experimenta el material que se acumula en el interior de la cámara. La primera cámara se abre hasta después de un año de operación o más. Para esta zona se seleccionó un sanitario seco en alto, debido a que presenta mantos freáticos superficiales y contaminación de pozos por filtraciones

\footnotetext{
${ }^{25}$ Ibíd.

${ }^{26}$ Ibíd.

${ }^{27}$ SAWYER, Tom, ANDERSON, Ingvar. HILLERS, Astrid. ESREY, Steven. Cerrando el ciclo: saneamiento ecológico para la seguridad alimentaría. Segunda edición. México 2006
} 
provenientes de letrinas convencionales e inodoros. La introducción del sistema ha sido muy cuidadosa durante los últimos tres años: hasta ahora 135 familias cuentan con este sanitario, en diferentes poblaciones. Muchos de los sanitarios se han construido cerca de la casa, debido al poco espacio del que se dispone.

\section{Norte América Y Oceanía}

Otros sanitarios más populares en el mundo son los sanitarios de composta Carrusel de varias cámaras. En Noruega y Estados Unidos se han construido más de 30,000 unidades desde 1972. También en Suecia y en Australia se fabrica un sanitario compostero similar, en este último país bajo el nombre de Rota-Loo. Además de venderse en Australia y Nueva Zelanda, ya hay algunos en las islas del Pacífico del Sur.

El diseño del Carrusel consta de una cámara subterránea de procesamiento en forma de tanque cilíndrico, dentro de la que hay otro tanque cilíndrico más pequeño que gira sobre un eje. Este segundo tanque está dividido en cuatro cámaras (seis, en otros modelos). La cámara en uso está justo debajo del conducto de caída de la taza de sanitario. Una vez que la cámara se llena, se hace girar el tanque de tal manera que la siguiente cámara quede en el lugar de la anterior; así, cada cámara se va llenando en secuencia. El sistema está diseñado para que las cámaras se llenen a lo largo de un año, siempre y cuando se utilice de acuerdo con lo planificado. Cuando la última cámara está llena, el material más viejo se retira por una puerta de acceso; la primer cámara queda libre para continuar con la secuencia. Los líquidos se drenan por medio de unos orificios en la base del tanque giratorio, para hacerlos caer al tanque externo, donde se evaporan o se descargan a una cama de evapotranspiración. ${ }^{28}$

\footnotetext{
${ }^{28}$ Ibíd.
} 
En la republica Kiribati ubicada al noreste de Australia, se dio inicio a partir de un serie de proyectos pilotos un equipo de trabajo del Centro de Estudios Ambientales de la Universidad de Tasmania, junto con otro equipo local, probaron con éxito varios prototipos para sanitarios composteros en uno de estos prototipos se utiliza, como cámara de composta, un recipiente de plástico para basura con capacidad para 240 litros. El recipiente tiene ruedas para transportarse. Cada recipiente cuenta con un piso falso hecho de malla, colocado a una distancia sobre la base del recipiente, en el interior, que permite que los líquidos se cuelen hacia la base y de ahí fluyan por un tubo hacia una cama sellada de evapotranspiración. Se coloca uno de los recipientes debajo de la taza de sanitario, donde se deposita la excreta y se reemplaza con otro vacío cada vez que se llene el que se encuentra en uso. A pesar del alto grado de humedad relativa en la isla de Kiribati, los resultados preliminares señalan que el diseño produce, de manera exitosa, residuos innocuos similares al humus. ${ }^{29}$

Otro diseño exitoso es el sistema sanitario que diseñó David del Porto para Greenpeace y el Centre for Clean Development (Centro para el Desarrollo Limpio) destinado a los países de las pequeñas islas del Pacífico, el enfoque principal de esta iniciativa es la de cero descargas más que en la separación y reciclado de orina. La excreta se deposita en un petate de hoja de palma, que a su vez descansa en una red para pescar hecha de hilo de nylon, suspendida dentro de la cámara de asimilación, este sistema separa todos los líquidos. Periódicamente se agregan a través de la taza del sanitario de pedestal materia orgánica, como cáscaras de coco, viruta de madera, hojas o pedazos de verduras y alimentos. Esto se hace para proporcionar una fuente de carbón (energía) e incrementar la porosidad del material, facilitando con ello la circulación del aire en todo el montón. ${ }^{30}$ 
Para alargar el período de composta, las cámaras se utilizan de forma alternada y el humus que se retira sirve como acondicionador de suelo. Este tipo de sanitarios es de bajo mantenimiento.

Después de año y medio de uso, ninguna unidad de prueba ha liberado algún tipo de contaminante. Justo donde la contaminación ambiental es una de las principales preocupaciones, el sanitario CCD puede ser una solución sanitaria apropiada.

\section{África}

En Zimbabwe hace varios años que el saneamiento ecológico se introdujo, donde todos los enfoques se basan en las siguientes premisas: contar con un medio para remover la excreta humana del sanitario de forma segura y simple; preparar la excreta humana para su uso en la agricultura promoviendo la producción de humus y reduciendo lo más que se pueda la contaminación de los mantos freáticos y la atmósfera.

Por lo demás, el saneamiento ecológico concuerda con el enfoque actual de confianza en sí mismo, que alienta en las familias que habitan zonas rurales cavar pozos propios y cultivar hortalizas para autoconsumo. Los economistas locales ven un valor económico neto al considerar el valor que tiene como recurso el producto que se obtiene de los sanitarios ecológicos.

\section{América Central}

En América Central y México se construye el LASF el cual es una versión mejorada del sanitario vietnamita EI CEMAT (Centro Meso-Americano de Estudios sobre Tecnología Apropiada) lo introdujo en Guatemala en 1978 y en los últimos veinte años se han construido miles de ellos en América Central, especialmente en El Salvador. Ha 
tenido un desarrollo similar en México, donde se promueve con el nombre Sanitario Ecológico Seco. ${ }^{31}$

La humedad es el factor de riesgo más importante en un sistema sanitario basado en la deshidratación; pero con agregar un calentador solar a la cámara de proceso se reduce dicho riesgo. Después de algunos experimentos con calentadores solares en Tanzania, el concepto se desarrolló en México y posteriormente, en El Salvador y Vietnam.

En el Salvador en los año 1994 a 1997 el proyecto Tecpan cuyo objetivo fue el probar y desarrollar un sistema sanitario basado en la deshidratación, con desviación de orina, y calentador solar para un sanitario con una sola cámara de tratamiento. Durante varios años se han utilizado 36 prototipos en hogares de la comunidad de Tecpan, cerca de San Salvador. Los resultados del proyecto demostraron que funciona bastante bien, la mayoría de las unidades de prueba se mantienen perfectamente secas, libres de malos olores y sin moscas, el calentador solar acelera el proceso de deshidratación. ${ }^{32}$

Otra experiencia exitosa y que apunta a solucionar las dos problemáticas comunes que son la carencia de servicios públicos y la contaminación ambiental, se da en San Luis Beltrán es un barrio periurbano ubicado al norte de la ciudad de Oaxaca, México.

A finales de los años ochenta un técnico de Centro de Innovación en Tecnología Alternativa (CITA), una ONG nacional, logró convencer a unas pocas familias de instalar sanitarios secos con desviador de orina. Para comenzar, se construyeron 35 unidades

\footnotetext{
${ }^{31}$ ESREY, Steven. GOUGH, Jean. RAPAPORT, Dave. SAWYER, Ron. SIMPSON-HEBERT, Mayling. VARGAS, Jorge. Saneamiento ecológico. Agencia Sueca de Cooperación Internacional para el Desarrollo/Fundación Friedrich Ebert-México. México. 1999. 101pag.

${ }^{32}$ Ibíd.
} 
con el apoyo de la Secretaria de Obras Públicas. Al principio los habitantes dudaron del funcionamiento de los sanitarios pero con el tiempo se demostró que funcionaba que no había presencia de moscas, ni de malos olores, fue así como las demás familias se interesaron en tener su sanitario seco. A través del apoyo del presidente e municipal se lograron construir 140 tazas. ${ }^{33}$

En sólo dos años San Luis fue la primera comunidad en el Estado, y quizá en el País, en resolver de una vez por todas, el problema de la disposición de excretas. Cinco años más tarde, convencidos de los beneficios de un sistema seco, los habitantes de San Luis Beltrán rechazaron la oferta de las autoridades municipales para construir un sistema de drenaje convencional. Estaban al tanto de los serios conflictos originados en casos similares, donde una comunidad acabó recibiendo las aguas negras de sus vecinos de arriba, desde que los sanitarios secos se introdujeron en San Luis, se evidencia menos contaminación en el río, y sus aguas son más seguras para el consumo. $^{34}$

El sistema de saneamiento ecológico que se usa en San Luis Beltrán llamó la atención de Clara Sherer, esposa del gobernador de Oaxaca y presidenta de la Dirección Integral de la Familia (DIF) estatal. La Sra. Sherer decidió promocionar los sanitarios secos y ahora pueden contarse unos 27,000 sanitarios ecológicos registrados en el estado. (César Añorve (1998), comentario personal).

\section{Sur América}

\section{Ecuador}

Desde 1985, en la provincia de Cotopaxi, en la región andina de Ecuador, optaron por un sistema de reciclaje, en un intento de subsanar el problema de pérdida de

\footnotetext{
${ }^{33}$ SAWYER, Tom, ANDERSON, Ingvar. HILLERS, Astrid. ESREY, Steven. Cerrando el ciclo: saneamiento ecológico para la seguridad alimentaría. Segunda edición. México 2006

${ }^{34}$ Ibíd.
} 
fertilidad del suelo en las regiones a gran altura de 3,500 a 4,000 metros sobre el nivel del mar. Se han construido unos 300 sanitarios de doble cámara con tapas que hacen de calentadores solares. Debido a la sequedad de la atmósfera, en esta región no hubo necesidad de desarrollar técnicas para desviar la orina. Después de cada uso, se espolvorea aserrín y/o cenizas.

Cada cámara se utiliza por seis meses antes de cambiar a la siguiente, y cada una tiene una tapa hecha con un bastidor de madera. Este bastidor se cubre con lámina de acero galvanizado, pintada de negro para que absorba la energía solar y contribuya al proceso de deshidratación. Este material una vez deshidratado en reincorporado al suelo para proporcionarle nutrientes.

\section{Chile}

El Desarrollo de las Letrinas Secas en Chile recalca que una de las ventajas de estos sistemas, es que las letrinas secas, es una tecnología que la hace aplicable en zonas desérticas, como el norte de Chile, con serios problemas de abastecimiento de agua. El sistema se caracteriza por tratamiento in situ de las excretas, separación de orina y feca, descomposición anaeróbico y/o aeróbico y unidades de tipo familiar.

Este tipo de letrina nunca se había implementado a gran escala, sólo se habían construido algunos prototipos en Valparaíso y Santiago, los cuales arrojaron resultados alentadores debido a las ventajas con respecto al uso de pozos sépticos. Por ejemplo, no existía peligro de inundación y/o derrumbe.

A raíz del terremoto del año 1985, se desarrolló un programa de emergencia que contempló la construcción e instalación de un centenar de letrinas en la provincia de San Antonio. Posterior al terremoto de 1995, que afectó severamente la Provincia de San Antonio se inició un programa de difusión y construcción de letrinas aboneras de 
tambor. Este proyecto consideró la construcción cerca de 200 soluciones por autoconstrucción.

Después de un estudio técnico y social de letrinas aboneras en los años 1988-1989 donde se evaluaron en las Localidades de la Provincia de Valparaíso y San Antonio, prototipos de letrinas aboneras de tambor, cuyos resultados más relevantes fueron la importancia del tema cultural y capacitación en el éxito de su uso y mantenimiento, así como la necesidad de la gente de contar con un baño completo más que un espacio solamente dispuesto para defecar. Este estudio fue el punto de partida para que en 1994, vecinos de Valencia Alto, población ubicada en los cerros periféricos de la ciudad de Quilpué, V región, construyeron asesorados por CETAL y por autoconstrucción las primeras 12 Unidades Sanitarias Secas. Se les llamo Unidades Sanitarias para marcar la diferencia a una simple letrina, pues se incorporaron urinario, lavamanos y ducha, quedando el agua disponible para otros usos y libres de contaminación fecal.

Los resultados, a cinco años de uso fueron alentadores: no hubo problemas de olores (6 Unidades están integradas a las casas), existe control total de moscas, se eliminó todo contacto humano y del medio ambiente con material fecal no descompuesto / higienizado.

Posterior a esta experiencia en Chile se han construido cerca de 70 unidades sanitarias secas con aportes de entidades Gubernamentales, internacionales, maestros, ayudantes beneficiarios y externos, estas unidades se han construido en localidades rurales dispersas. ${ }^{35}$

\section{Argentina}

Así como Chile y otros países lo han considerado sistemas para zonas rurales Argentina lo considera una nueva alternativas ecológica para el saneamiento sobre todo

\footnotetext{
${ }^{35}$ Montecinos. Vicente, Unidades sanitarias secas: Una solución económica y ambientalmente sustentable para el saneamiento básico, Corporación CETAL 2002-2009.
} 
en zonas que han catalogado como de riesgo sanitarios en la distintas provincias del país las cuales están clasificadas en: ALTO (entre 50 y 100\%): conurbano bonaerense, San Juan, La Rioja, Catamarca, Tucumán, Salta, Jujuy, Santiago del Estero, Chaco, Formosa, Corrientes, Entre Ríos y Misiones. MODERADO (entre 40 y 50\%): Buenos Aires, Santa Fe, Córdoba, San Luis y Mendoza. BAJO (entre 0 y 40\%): La Pampa, Neuquén, Río Negro, Chubut, Santa Cruz y Tierra del Fuego. Esto demuestra que el servicio de saneamiento básico de este país es del 47\%. ("Ecosan" una nueva alternativa ecológica para el saneamiento en Argentina).

\section{Bolivia}

Según un estudio antropológico del uso de letrinas ecológicas en Bolivia, una de las principales preocupaciones es conseguir el desarrollo de las poblaciones más necesitadas, la mejora de sus condiciones de salud y una vida digna. A nivel regional, la inequidad en el acceso a los servicios de saneamiento es una realidad latente, especialmente en las poblaciones rurales para quienes el acceso a estos sólo puede ser alcanzado por el $46 \%$, de las personas a diferencia de las poblaciones urbanas donde este porcentaje llega al $85 \%$. ${ }^{36}$

El estudio antropológico del uso de letrinas ecológicas, tuvo como objetivo la obtención de información cuantitativa y cualitativa para elaborar una nueva estrategia de intervención en saneamiento para la zona rural andina en Bolivia, ya que los pobladores de las comunidades aimaras y quechuas ven la enfermedad como un desequilibrio entre la relación entre el hombre y la naturaleza o como una reacción de la pachamama cuando esta no es tratada con deferencia, siendo el olor un factor para la transmisión de enfermedades. ${ }^{37}$ Los principales resultados del estudio de campo dieron que las letrinas ecológicas familiares en un $70 \%$ de las letrinas domésticas son

${ }^{36}$ Estudio Antropológico Del Uso De Letrinas Ecológicas En Bolivia, 2008.
${ }^{37}$ Ibíd. 
utilizadas para fines sanitarios. De estas, el 39\% son utilizadas de manera frecuente, y el $31 \%$ lo hace de forma eventual. ${ }^{38}$

\section{Uso sanitario de las letrinas ecológicas familiares}

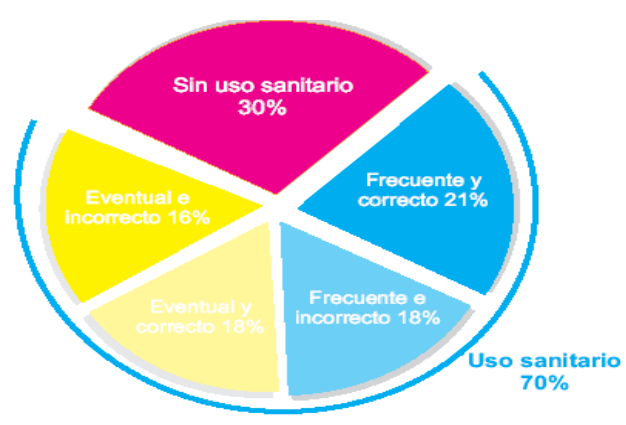

Los factores que explican el uso de las letrinas ecológicas desde el ámbito antropológico se refieren a que la población indígena mayoritaria en el área rural andina de Bolivia tiene una cosmovisión particular que se ha visto trastocada con algunas prácticas asociadas con el uso de la letrina ecológica.

Desde la percepción del riesgo a través de factores de desagrado, como moscas y olores. Una vez que son identificados, se suspende el uso de la letrina, siendo aún difícil la asociación entre estos factores y las fallas en operación y mantenimiento. ${ }^{39}$

Desde el ámbito agronómico, al final de un año la cantidad de abono generada por una letrina familiar son de $55 \mathrm{~kg}$ de abono sólido y $2.7 \mathrm{~m}$ de abono líquido. El abono líquido podría ser utilizado en el transcurso del año de manera constante; mientras que el abono sólido estaría disponible en períodos de un año y medio, donde se llegaría a recolectar cerca de $80 \mathrm{~kg} .{ }^{40}$

\footnotetext{
${ }^{38}$ Ibíd.

${ }^{39}$ Ibíd.

${ }_{40}$ Ibíd.
} 


\section{EXPERIENCIAS EN COLOMBIA}

En Colombia el tema de saneamiento alternativo sostenible ha tenido en los últimos años un proceso de difusión y de experiencias en el territorio, tanto así que se consolidó la Mesa de Trabajo en Saneamiento Alternativo Sostenible a la cual asisten la Secretaría Distrital de Salud, la Organización Panamericana de la Salud, la Universidad del Bosque a través de su Instituto de Salud y Ambiente, Fundemar, El Instituto de Ambiente de Estocolmo SEI, Procco Colombia, Uniminuto y Plan Internacional. Esta mesa tiene como objetivos la gestión intersectorial, estandarización de aspectos técnicos a través de la elaboración de un protocolo que unifique las experiencias de saneamiento ecológico en Colombia y la difusión del saneamiento ecológico apoyado en cursos y talleres nacionales e internacionales así como la difusión de las experiencias en espacios como congresos y demás.

En el país el saneamiento ecológico se ha desarrollado en diversas ciudades con motivaciones diferentes que buscan la sostenibilidad ambiental, y solucionar problemáticas sociales como la falta de saneamiento básico especialmente en zonas rurales. A continuación se mencionara las experiencias encontradas en el país.

En Providencia se han instalado 120 unidades de sanitarios secos a través de un proyecto de interés social, estas se encuentran en operación con algunas debilidades en la implementación.

En Quibdó se han construido unidades de sanitarios secos y cosecha de agua lluvia la cuales se encuentran en operación pero aún no se tiene una información exacta del estado en el cual se encuentran.

En el Valle del Cauca se encuentra un sanitario seco recién instalado como sanitario público a través de un proyecto social, la motivación principal para la 
construcción de este se debió a la protección ambiental y la generación de abono a partir de la excreta humana.

En la Granja Escuela Miravalle Cali (Valle), la construcción de los sanitarios secos se dio como un sistema alternativo demostrativo, con una función educativa además de dar respuesta al sistema existente de tanque séptico el cual funcionaba inadecuadamente.

En Tumaco se construyeron en el 2004 cerca de 80 unidades prefabricadas de sanitarios secos a través de un proyecto de interés social, en este se han evidenciado fallas en la aceptación al sistema ya que muchas no están siendo usadas por las familias, argumentando la presencia de olores desagradables, y moscas, además muchas se encuentran construidas fuera de la vivienda, esto se debe a que las familias no tiene suficiente conocimiento sobre el uso y mantenimiento que se le debe dar a las unidades.

En San Andrés se encuentran 4 unidades de sanitarios secos en operación y que funcionan como sanitarios públicos, la motivación para la construcción de este sistema fue la falta de suministro colectivo de agua y un alto nivel freático.

Según el estudio de minimización de los factores de riesgo para la enfermedad del dengue y de origen hídrico en San Andrés realizado en el 2005 por la Organización Panamericana de la Salud OPS y la Organización Mundial de la Salud OMS, se planteó una estrategia de gestión integrada donde confluyen diferentes componentes como son: el ambiente, la epidemiologia, antropología, participación social, la información, educación y la comunicación, con el fin de atacar las graves problemáticas de consumo y el almacenamiento de agua; es así como se diseñan los MOFASA (Modulo sanitario familiar), que consta de unidad sanitario seco más cocina, con el fin 
de dar un manejo adecuado a la captación de agua lluvia, el manejo de los residuos sólidos, vertimientos de aguas grises y manejo de excretas.

En Quindío específicamente en la Tebaida (Armenia) y en la Granja ecológica albergue azul (Caldas) se han difundido más como proyectos ambientales a escala de granja como los sani-huertos, los sanitarios secos y la cosecha de agua lluvia, los cuales se encuentran operando en este momento, la motivación principal para uso de este sistema ha sido la protección ambiental, minimizar la contaminación de agua subterránea, la generación de abono y la minimización en el consumo de agua y la no dependencia del acueducto municipal.

En Boyacá se han construido 38 unidades sanitarias secas con cosecha de agua lluvia y manejo de aguas grises a través de proyectos de interés social, 30 de ellas han sido construidas por la Empresa de Energía de Boyacá EBSA, en municipios que trabajan la minería artesanal como son Sogamoso, Tópaga, Gámeza, Corrales, Tasco, Socha y Paipa, cuatro familias por cada municipio exceptuando Tasco donde trabajaron con seis, estas familias pertenecen al programa del ICBF de "Educadoras Familiares"; los objetivos de este proyecto han sido asegurar el agua para consumo, disminuir la prevalecencia de enfermedades relacionadas con el almacenamiento, consumo y distribución del agua, la proliferación de vectores, a nivel ambiental la contaminación en agua, suelo y reincorporar nutrientes a este, por último a nivel social mejorar la calidad de vida, cambiar hábitos higiénico-sanitarios, lograr una aceptación de la familia al sistema y no generar sobrecosto económicos a esta.

Lo anterior demuestra un gran interés y variedad de experiencias en Colombia pero también evidencia que es fundamental la capacitación y participación de las familias en todas las etapas de los proyectos para garantizar el éxito de los mismos, cabe anotar que si bien la inversión debe estar centrada en el desarrollo de infraestructuras físicas, debe hacerse énfasis en el fortalecimiento de estructuras sociales. 


\section{EXPERIENCIAS DISTRITALES}

En Bogotá se encuentran 21 unidades alternativas de saneamiento básico en seis localidades las cuales son: Usaquén, Suba, Chapinero, Rafael Uribe, Usme, y Ciudad Bolívar.

El desarrollo de estos proyectos especiales a través de las Empresas Sociales del Estado E.S.E., formulados y manejados por los Plan integrales de Entornos Saludables pertenecientes a Salud Pública de cada E.S.E., los cuales Corresponden a una herramienta fundamental de planeación y ejecución para el abordaje de los determinantes socio ambientales en los territorios; ya que su fin u objetivo atañe al análisis y articulación de las caracterizaciones adelantadas para individuo, familia, vivienda y entorno ambiental, núcleos abordados con la estrategia de Vivienda Saludable en años anteriores y los diagnósticos ambientales escolares. Con base en esta situación plantear tanto desde las competencias sectoriales como con gestión intersectorial, planes de intervención bajo la postura integral y articulada de Entornos Saludables en las diferentes etapas del ciclo vital. ${ }^{41}$

Algunos de los criterios de inclusión de las familias son:

- En condiciones de vulnerabilidad con deficiencias en el acceso a los servicios públicos (Acueducto y Alcantarillado)

- Ubicadas en zonas periurbanas y rurales.

- Estratos 1 y 2.

- Trabajadores informales o dedicados a actividades agropecuarias de subsistencia y de mediana escala.

\footnotetext{
${ }^{41}$ Lineamiento Planes de Entornos saludables, Secretaria Distrital de Salud 2009.
} 
- Familias conformadas con un promedio de 5 integrantes la mayoría menores de edad y/o adulto mayor.

- Población de origen campesino, desplazada.

- La identificación se hace a través de la estrategia vivienda saludable.

- Problemas de salud relacionados con la falta de servicios públicos y condiciones de saneamiento desfavorables.

- Apoyo en la construcción, voluntad de uso y mantenimiento.

Para el caso del Hospital de Chapinero cuentan con 4 familias beneficiadas, de la UPZ 89 San Isidro Patios en los barrios Bosques de Bellavista, San Isidro y La Esperanza. Estas familias son pertenecientes a estratos 1 y 2 dedicadas principalmente a la informalidad. Dentro de las problemáticas las de mayor importancia son la carencia de servicios básicos; dos familias sin acueducto y el total de ellas sin alcantarillado.

Estas familias están compuestas por 8 integrantes en promedio, la mayoría de ellos menores de 18 años, las viviendas están ubicadas en zonas en proceso de legalización por encontrarse en áreas de protección.

Avances de la Experiencia de Sanitarios Ecológicos: Utilización del biosólido como insumo para la producción de hortalizas, reconocimiento por parte de la comunidad de las ventajas del sanitario ecológico secos, reducción en la contaminación de fuentes de agua y contribución al manejo racional del recurso hídrico, contribución a la solución de la problemática de manejo de excretas en las viviendas de los barrios donde se ha implementado, mejoramiento de las condiciones del entorno.

Pero como toda alternativa es pertinente mencionar algunas ventajas y desventajas identificadas a partir de la experiencia del Hospital de Chapinero: 
Ventajas: Permite hacer uso racional del agua, evita la contaminación de fuentes de agua superficiales y subterráneas, permite la obtención de subproductos (Biosólido), evita los riesgos a la salud pública por la disposición inadecuada de excretas, y aporta a la economía familiar.

Limitantes: Disponibilidad de recursos para su construcción, su mantenimiento demanda mayor esfuerzo físico, factores culturales, dificultad para la disposición final del material, disponibilidad de material secante.

Entre las expectativas con las que se cuenta, se busca estandarizar el proceso de saneamiento ecológico, extender la propuesta de Sanitario Ecológico a otros sectores de la población.

Para el caso de Hospital Rafael Uribe cuentan con una unidad que beneficia a una familia con siete integrantes entre ellos niños menores de edad, a partir de esta experiencia han iniciado una investigación acerca del uso del subproducto llamado biosólido basándose en exámenes coprológicos de este material en tratamiento, se inicio el uso de un biopreparado orgánico con propiedades antihelmínticas (eucalipto, ajo, ajenjo, altamisa, menta, perejil, tomillo, ruda, zanahoria) con uso de levadura y azúcar para elevar la temperatura.

En la Localidad de Suba se dio inicio a este proyecto en el año 2006, Su objetivo fue implementar cinco unidades alternativas de saneamiento como modelo piloto para su estudio de factibilidad técnica y social, que permitiera mostrar a la comunidad (principalmente de la Vereda Chorrillos) un sistema diferente para disponer sus excretas además del aprovechamiento del agua lluvia y mejoramiento de la calidad de la misma mediante la implementación de filtros de vela para el agua de consumo.

El IICA apoyó las investigaciones respecto al manejo del biosólido (excreta) a través de talleres de preparación de bocashi, para complementar este proceso el Hospital construyó aboneras en los predios de las familias para facilitar la preparación 
del abono, así mismo realizaron pruebas con la orina donde se tenían tres parcelas demostrativas, en una se aplicó la orina sin diluir, en la otra diluida con agua, y un testigo donde no se hizo ninguna aplicación. Esto permitió comprobar las bondades de la utilización de la orina como fertilizante, a través de la observación y las notas de campo que tomaron las respectivas familias.

\section{MARCO CONCEPTUAL}

Para efecto de la investigación es necesario abordar conceptos claves como el de desarrollo sostenible, debido a que la alternativa de sanitarios secos se constituye como una propuesta ambientalista que resignifique el comportamiento del hombre frente al ambiente.

\section{Desarrollo Sostenible}

El concepto de desarrollo sostenible tiene sus antecedentes en la ecología tropical de fines del siglo XIX e inicios del XX. Surge en los años setenta, sucediendo a los conceptos de desarrollo, desarrollo rural, desarrollo integral, y se elabora simultáneamente con las construcciones conceptuales del ecodesarrollo. ${ }^{42}$

El discurso del desarrollo sostenible se fue legitimando, oficializando y difundiendo ampliamente a raíz de la conferencia de las Naciones Unidas sobre medio ambiente y desarrollo celebrado en Río de Janeiro en 1992. Sin embargo, la conciencia ambiental emerge en los años 70 con la Primavera Silenciosa de Rachel Carson, y se expande, luego de la Conferencia de las Naciones Unidas sobre el medio ambiente Humano, celebrada en Estocolmo en $1972 .^{43}$

\footnotetext{
${ }^{42}$ VAN HOOF, Bart. PEREZ, Carlos. GIRALDO, Nicolás. Problemática ambiental y concepto de desarrollo sostenible.2000.

${ }^{43}$ LEFF, Enrique. Saber Ambiental: Sustentabilidad, Racionalidad, Complejidad, Poder. 2004.
} 
A partir del las reflexiones generadas desde los conceptos de cultura, ambiente y desarrollo se aporta a la generación de una postura frente a la definición de desarrollo sostenible en el marco de lo que implica su dependencia en función de los tipos de cultura que emergen de la interacción histórica del hombre con su realidad ecosistémica. Básicamente se plantea como el desarrollo sostenible se debe humanizar, es decir, una reconversión al modelo de sociedad industrial occidental, la cual está basada en el crecimiento irracional, el consumismo, el productivismo, la acumulación de capital y la estandarización indiscriminada del mundo, lo cual conlleva a la dependencia energética de combustibles fósiles, la guerra y en sí, a la insostenibilidad. ${ }^{44}$

El conflicto naturaleza-cultura se genera a partir del modelo de desarrollo de la modernidad asociado a la construcción de la sociedad industrial avanzada. Se debe tener en cuenta que "La cultura no puede ser entendida sin considerar la base biológica sobre la cual se ha construido, no existe pues una dicotomía entre cultura y naturaleza". ${ }^{45}$

Ahora bien cuál es la relación entre ecosistema y cultura, "se parte de concebir el ecosistema como un potencial productivo, como un medio utilizado por las diferentes especies, entre ellas el hombre". ${ }^{46}$

Por lo tanto el desarrollo sostenible precisa una redefinición en cuanto al concepto simplista de satisfacción de necesidades presentes, sin poner en peligro las futuras generaciones, dado que el desarrollo sostenible es una administración correcta de los recursos que tiene en cuenta la limitación de los bienes y servicios en términos

\footnotetext{
${ }^{44}$ GONZALES. Francisco. Ensayo: Reflexiones acerca de la relación entre los conceptos de: ecosistema, cultura y desarrollo. Pontifica Universidad Javeriana. Bogotá. Colombia. 1999.

${ }^{4}$ Ibíd.

${ }^{46}$ Ibíd.
} 
culturales, económicos y ambiéntales. Para ello debe cumplir una serie de características que involucran todas las dimensiones del ambiente y no limitarse a utilizar los bienes y servicios ambientales eficientemente sino que dicho de otro modo tratar de entender la relación estrecha entre el hombre y la naturaleza dentro del contexto donde esta se encuentre.

Por otra parte, la gestión ambiental es un proceso que está orientado a resolver, mitigar y/o prevenir los problemas de carácter ambiental, promoviendo la institucionalidad de una manera sistemática dentro del contexto local global, de esta manera, la gestión ambiental debe actuar de manera que las políticas ambientales tengan en cuenta a todos los involucrados y propendan una gestión integral de los bienes ambientales.

Entendiendo la definición de estos conceptos, se puede decir que la articulación entre la gestión ambiental y el desarrollo sostenible está basada principalmente en la relación del hombre- naturaleza, vista desde el contexto de esta con su patrimonio biofísico, cultural, dicho de otro modo, la gestión ambiental debe promover el desarrollo sostenible mediante el desenvolvimiento de las potencialidades con su entorno y manejo de los bienes ambientales de manera que, garanticen sus permanencia en el tiempo y el espacio.

Es así como se plantean dos opciones; una de éxito que es la de "comprender el sistema natural apoyándonos en él para conservar la vida; de nosotros de la comunidad y la de los demás, que nos implica leer correctamente los mensajes de la naturaleza y a partir de ellos construir sistemas industriales y agropecuarios basados en la comprensión de los ciclos biogeoquímicos y las relaciones ecosistémicas; es decir construir unas formas culturales que permitan garantizar la vida". ${ }^{47}$

${ }^{47}$ Ladrón, 1999 
La otra opción es el camino a la destrucción de la vida y del hombre como especie inmersa en ella, la guerra permanente entre todos por los recursos, lo cual acelera los procesos de destrucción de la misma. ${ }^{48}$

Para poder interpretar la problemática ambiental es necesario comprender que "La cultura es un sistema del cual no podemos eliminar el sistema biofísico, pues es parte vital; la naturaleza no está afuera, está adentro, porque sin su presencia no existe la cultura, no existe el hombre, mente y cuerpo son indivisibles, la naturaleza y cultura también", y así abordar y dar respuesta a la resolución de las mismas. ${ }^{49}$

Para consolidar la sostenibilidad se debe tener en cuenta que los cambios se deben generar no solo como individuo sino como población en el marco de la dinámica ecosistémica, el entendimiento de la cultura como parte de la evolución biológica y un momento y una instancia en los procesos de la biosfera.

Ahora bien, la apuesta para la gestión ambiental es concebir el conocimiento como un agente de construcción de carácter universal, en función del tiempo y el espacio; como herramienta para la interpretación del mundo que aporte a la resolución de problemas ambientales a través de mecanismos sociales, de acuerdo a una interacción hombre-naturaleza, es decir, la concepción de la sostenibilidad ambiental como sostenibilidad cultural, contemplando sistemas asociados a estrategias integrales, cambios en la pautas conductuales, cambios en el sistema económico, en la reconversión tecnológica e inclusión de la visión sistémica asociada a la investigación, coordinación institucional y la participación comunitaria.

\footnotetext{
${ }^{48}$ GONZALES. Francisco. Ensayo: En busca de caminos para la comprensión de la problemática ambiental. Pontificia Universidad Javeriana. Bogotá. Colombia.2006

${ }^{49}$ GONZALES. Francisco. Ensayo: Reflexiones acerca de la relación entre los conceptos de: ecosistema, cultura y desarrollo. Pontifica Universidad Javeriana. Bogotá. Colombia. 1999.
} 


\section{Calidad De Vida}

El concepto de calidad de vida tiene diferentes interpretaciones y depende del punto de vista desde el cual se aborde, y está asociado al concepto de desarrollo económico. En los países desarrollados probablemente el término calidad de vida haga referencia a satisfacer necesidades no prioritarias, contrario a los países en vía de desarrollo, donde calidad de vida alude a la satisfacción de las necesidades básicas como son la educación, la salud, la vivienda, la alimentación, etc.

Calidad de vida es "la capacidad que posee el grupo social ocupante de satisfacer sus necesidades con los recursos disponibles en un espacio natural dado. Abarca los elementos necesarios para alcanzar una vida humana decente." 50 Actualmente, es un esfuerzo de toda acción política tanto a nivel nacional como a nivel internacional para lograr dignidad en la vida humana.

Actualmente las relaciones entre el crecimiento económico y la calidad del ambiente, se evidencia a través de los tipos de extracción, producción y consumo de bienes y servicios, que han contribuido a una mayor desigualdad social a una explotación destructiva y despilfarradora de los recursos naturales. Además, "el aumento de la productividad dado por el avance tecnológico, junto al explosivo crecimiento de la población, tanto en el ámbito rural, como urbano, son las causas que explican la baja calidad de vida y el deterioro del medio ambiente." 51

Sin embargo, "el mejoramiento de la calidad de vida que se plantea como principal objetivo del desarrollo social, económico y cultural, pasa por la búsqueda necesaria de un equilibrio entre la cantidad de seres humanos y los recursos, así como la protección del medio ambiente." 52

\footnotetext{
${ }^{50}$ GILDENBERGER, C. 1978, Desarrollo y Calidad de Vida. http://www.eumed.net/cursecon/libreria/2004/hjmc/2a.htm

${ }^{51}$ Ibíd.

52 Ibíd.
} 


\section{Nivel De Vida}

Es el grado de capacidad que tiene una persona o grupo social para satisfacer sus necesidades vitales más imperantes. Se dice que es alto porque sus satisfactores son hartos en cantidad y calidad. Por el contrario, es bajo porque estos no presentan tanto calidad como cantidad en su consumo. Un ejemplo puede ser el abasto de la canasta básica alimenticia. Mientras una pequeña parte de la población consume más de 4 días a la semana carne, el resto sólo la prueba quizás una vez.

\section{Desarrollo}

El postulado básico del Desarrollo a Escala Humana es que el desarrollo se refiere a las personas y no a los objetos. Por lo tanto el desarrollo "será aquel que permita elevar más la calidad de vida de las personas". La calidad de vida dependerá de las posibilidades que tengan las personas de satisfacer adecuadamente sus necesidades humanas fundamentales. ${ }^{53}$

Es importante entender las diferencias entre las necesidades y los satisfactores de esas necesidades ${ }^{54}$, combina dos criterios de división: según categorías existenciales y según categorías axiológicas. Esta combinación permite reconocer, por una parte, las necesidades de Ser, Tener, Hacer y Estar; y, por la otra, las necesidades de Subsistencia, Protección, Afecto, Entendimiento, Participación, Ocio, Creación, Identidad y Libertad.

Posterior a esta diferenciación de conceptos definen dos postulados, Primero: las necesidades humanas fundamentales son pocas, delimitadas y clasificables. Segundo:

\footnotetext{
53 MAX-NEEF, Manfred. ELIZALDE, Antonio. Hopenhayn, Martin. Desarrollo a Escala Humana una opción para el futuro. Development Dialogue. Número especial 1986. Santiago, Chile. http://www.dhf.uu.se/pdffiler/86_especial.pdf ${ }^{54}$ Ibíd.
} 
las necesidades humanas fundamentales son las mismas en todas las culturas y en todos los períodos históricos. Lo que cambia a través del tiempo y de las culturas es la manera o los medios utilizados para la satisfacción de las mismas. Por lo tanto cada sistema económico, social y político adopta diferentes estilos para la satisfacción de las mismas necesidades humanas fundamentales. En cada sistema éstas se satisfacen (o no) a través de la generación (o no generación) de diferentes tipos de satisfactores. ${ }^{55}$

A través de la elección de satisfactores se define la cultura, las necesidades humanas son las mismas en los diversos tipos de sociedades, lo que cambia en la cantidad y calidad de los satisfactores elegidos y/o la posibilidad de acceder a estos. Alguna de las consecuencias del cambio cultural es abandonar los satisfactores tradicionales y reemplazarlos por otro nuevos y diferentes.

Para construir una filosofía y política de desarrollo humanistas es necesario tener en cuenta las relaciones que se establecen o que pueden establecerse entre las necesidades y sus satisfactores.

Otra relación interesante que fundamenta esta investigación es la relación del desarrollo social que llevara al desarrollo económico sostenido. Así las economías que mejor han funcionado en los últimos tiempos han apostado fuerte a grandes inversiones continuadas en sus recursos humanos, y ahora están cobrando amplios réditos en productividad y competitividad por ello. Indica 'el papel de la educación y la salud pública ha sido el eje fundamental para contribuir al cambio económico y social en el mundo entero. ${ }^{56}$

\footnotetext{
${ }^{55}$ Ibíd.

${ }^{56}$ Ibíd.
} 


\section{Pobreza}

El concepto tradicional de pobreza es muy limitado, ya que se refiere exclusivamente a la situación de aquellas personas que se hallan por debajo de un determinado nivel de ingreso convirtiendo esto en una noción estrictamente economicista.

La expresión "la pobreza inevitable sigue siendo pobreza". "La medición de la pobreza - concluye Sen- ha de considerarse como un ejercicio descriptivo, que evalúa las penurias de las personas en términos de los "estándares prevalecientes de necesidades. Es un ejercicio empírico y no ético" ${ }^{57}$

Por lo tanto Max Neef sugiere referirse a pobrezas y no pobreza, ya que cualquier necesidad humana fundamental que no es satisfecha revela una pobreza humana, como ejemplo esta la pobreza de Protección referente al sistema de salud, violencia entre otros, pobreza de afecto, de participación y así sucesivamente. Pero las pobrezas no son sólo pobrezas, son mucho más que eso. Cada pobreza genera patologías, toda vez que rebasa, por su intensidad o duración, ciertos límites críticos.

Según Amartya Sen en las Distintas Caras de la Pobreza, no se trata de contar pobres se trata de entender que la vida humana se puede empobrecer de muchas maneras: "Los ciudadanos sin libertad política -ya sean ricos o pobres- están privados de un componente básico del buen vivir. Lo mismo se puede decir de las privaciones sociales como el analfabetismo, la falta de sanidad, la atención desigual a los intereses de las mujeres y las niñas, etcétera." Claro está que "Tampoco podemos olvidar los vínculos entre las penurias económicas, políticas y sociales".

Concluyendo, se hace necesario avanzar hacia una visión amplia y real acerca de los conceptos de progreso y pobreza. Debe examinarse cuáles son las "capacidades de

\footnotetext{
${ }^{57}$ BOLTVINIK. Julio. Amartya Sen Y La Pobreza. Publicado en La Jornada, México, 28 y 29 de octubre de 1998. http://www.geocities.com/wallstreet/floor/9680/nobel.htm?200931
} 
funcionamiento" de las personas en la vida. Cómo el contexto social les permite, o no, satisfacer desde las necesidades básicas de nutrición, salud, vivienda, hasta las de cultura, participación, desarrollo, productividad, tener una vida estimulante, autoestima. Todo ello puede y debe medirse. Hay progreso cuando hay avance en esas capacidades. $^{58}$

\section{Saneamiento Básico}

El saneamiento ambiental básico es el conjunto de acciones técnicas y socioeconómicas de salud pública que tienen por objetivo alcanzar niveles crecientes de salubridad ambiental y preservación de las condiciones sanitarias óptimas de:

- $\quad$ Fuentes y sistemas de abastecimiento de agua para uso y consumo humano.

- $\quad$ Disposición sanitaria de excrementos y orina, ya sean en letrinas o baños.

- Manejo sanitario de los residuos sólidos, conocidos como basura.

- $\quad$ Control de la fauna nociva, como ratas, cucarachas, pulgas, etc.

- Mejoramiento de las condiciones sanitarias y limpieza de la vivienda. ${ }^{59} 60$

\section{Sanitario Ecológico Seco}

El concepto del sanitario ecológico seco se desarrolló sobre las siguientes premisas: interrumpir la vía fecal-oral (ciclo ano-mano-boca), desarrollar el hábito de lavado de manos, aislar excretas del entorno, evitar la dispersión prematura de las heces fecales e impedir el contacto de la excreta con las personas. Estas premisas dieron origen al diseño de dos barreras: primaria o física para detener la contaminación

\footnotetext{
${ }^{58}$ KLIKSBERG, Bernardo. ¿Es posible una economía con rostro humano? Especial para El Universal Caracas, domingo 20 de abril, 1997. http://www.geocities.com/centrolebret/articulo01.html.

${ }^{59} \mathrm{http}: / / \mathrm{www} . \mathrm{monografias.com/trabajos26/saneamiento-basico/saneamiento-basico.shtml}$

${ }^{60}$ http://www.bvsde.ops-oms.org/cepis/e/cepisacerca.html
} 
por suelo, agua, aire, dedos, moscas y las barreras secundarias eminentemente de cultura sanitaria asociada a prácticas higiénicas de los usuarios. ${ }^{61}$

Los sanitarios secos cuentan con una taza especial separadora de orina, existen tanto modelos caseros como industriales. Tienen un depósito de orina en la parte delantera de la taza. Desde este colector, la orina fluye por una manguera hacia un pozo de absorción debajo o al lado del sanitario, se puede utilizar como fertilizante en las hortalizas (mezclar 1 parte de orina por 5 a 8 partes de agua). ${ }^{62}$

\footnotetext{
${ }^{61}$ GUERRERO María Teresa, TAMISET, Jan. MARTINEZ Raúl, HERNANDEZ Yolanda. Diseño y construcción de sanitarios ecológicos secos en áreas rurales. Universidad Autónoma de San Luís Potosí. México. 2006.

62 Ibíd.
} 


\section{AREA DE INVESTIGACIÓN}

\section{LOCALIDAD DE SUBA}

La localidad de Suba está ubicada en el extremo noroccidental de la ciudad y limita por el norte con el municipio de Chía, por el sur con la localidad de Engativá, por el Oriente con la localidad de Usaquén y por el occidente con el municipio de Cota.

Suba tiene una extensión total de $10.055,98$ ha, $6.033,67$ ha se clasifican como suelo urbano, 880 ha como suelo de expansión y 3.141,31 ha corresponden al suelo rural; dentro de estos tres suelos se localizan 1.754,66 ha de suelo protegido. Suba es la localidad con mayor área urbana del Distrito, con el 15,7\% de dicha superficie. El territorio de Suba es poco accidentado, pues existe solamente una larga colina que se extiende de sur a norte en la zona central; las características del relieve en esta región se pueden describir de la siguiente manera: un $78 \%$ de su superficie es plana, un $7 \%$ ondulada, un $10 \%$ poco quebrada y un $5 \%$ quebrada.

La zona está localizada a una altura mínima de 2.560 metros sobre el nivel del mar (msnm), a orillas del río Bogotá y a 2.700 msnm de altura máxima en la cumbre de la colina de la parte sur, con una temperatura promedio anual de 12,6. 


\section{VEREDA CHORRILLOS}

\section{LOCALIZACIÓN GEOGRÁFICA}
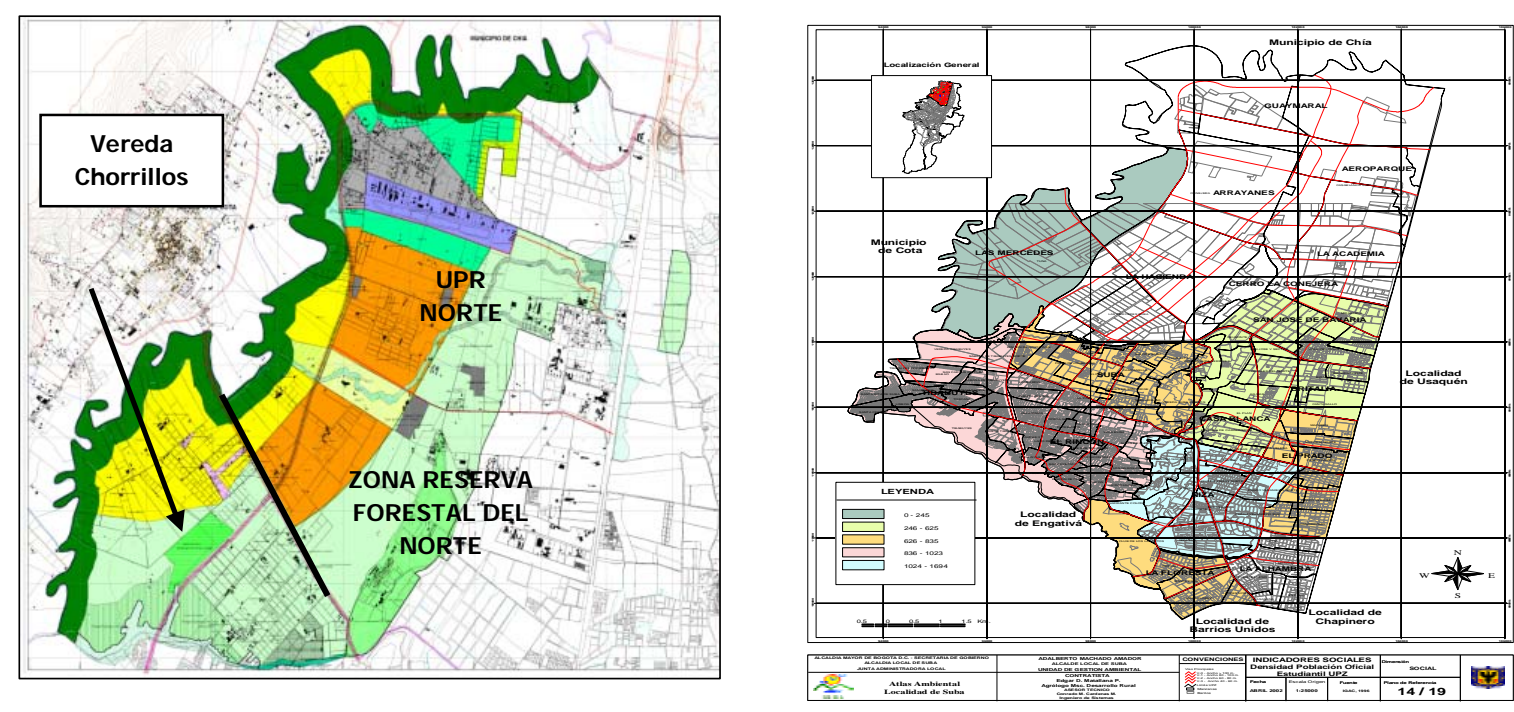

El Plan de Ordenamiento Territorial (POT), complementado con el documento Proyecto de Construcción Colectiva de la Biodiversidad Urbano Rural de la localidad de Suba desarrollado por el Instituto de Investigación de Recursos Biológicos Alexander Von Humboldt y la Secretaria Distrital de Ambiente han elaborado un documento en el cual ubica la zona rural de Suba en la UPZ Las Mercedes por fuera del perímetro urbano; está cuenta con cuatro sectores distribuidos por la Vía Suba-Cota desde el km 3.5 hasta el $6.5 \mathrm{~km}$. El sector I-Buenos Aires, Sector II- Central, Sector III- El Candil, Sector IV- Guaymaral. 


\section{GENERALIDADES}

La conformación territorial de la vereda Chorrillos data de más de 30 años, cuando este sector de la localidad de Suba estaba habitado por campesinos de la región del altiplano, los cuales se dedicaban al cultivo de la tierra, y actividades pecuarias. En la actualidad y a pesar del continúo desarrollo urbanístico de la ciudad, algunos de sus pobladores conservan aún estas costumbres. La vía principal de acceso vehicular pavimentada es la vía SUBA - COTA a la altura de los Kilómetros 2 a 7, en sentido oriente-occidente y abarcando 3 sectores; no cuenta con manzanas convencionales como en un casco urbano desarrollado, sino más bien, con una serie de caminos destapados que comunican hacia diferentes sectores de la vereda y que parten de la mencionada vía SUBA - COTA. Limita por el norte con el Aeropuerto Guaymaral, por el oriente con el Colegio El Salitre, por el sur con el humedal de La Conejera y el barrio Compartir, y finalmente por el occidente con el vecino municipio de Cota, Cundinamarca. El uso predominante del suelo presenta en mayor medida núcleos de actividad industrial, agrícola, pecuaria, deportiva, y en menor grado de actividades domésticas y comerciales.

Los habitantes de los 3 sectores de esta vereda carecen de servicios públicos domiciliarios como acueducto, alcantarillado de aguas residuales y pluviales, razón por la cual sufren de una inmensa problemática sanitaria y ambiental, generando una baja calidad de vida para sus residentes.

En la vereda encontramos diferentes tipos de población, de acuerdo a su actividad económica, habitantes que tan solo residen en la vereda, pequeños comerciantes, familias que dependen económicamente de las empresas de floricultura, desplazados y los que realizan actividades agropecuarias para su sustento, en esta población se observa que la gran mayoría residen aquí desde su infancia y son las familias más antiguas del sector, su tradición es netamente rural y manifiestan no contar con un apoyo institucional para el manejo técnico de sus animales. 
Según el aplicativo de Atención Primaria en Salud para el año 2005, de 532 habitantes registrados tenemos los siguientes datos: para el caso de género 256 habitantes pertenecen al sexo femenino y 276 al masculino; según rango de edad, 180 habitantes que se encuentran entre 1-14 años de edad, 111 habitantes entre los 15-26 años, 217 entre 27-59 años de edad y 24 habitantes mayores de 60 años. $^{63}$

Para el presente año, según la encuesta de la Alcaldía Local de Suba como producto del proyecto de las alternativas de saneamiento básicos información recopilada a través de 131 encuestas, la población total es de 728 habitantes compuesto por un 33\% niños y un 53\% adultos, el número de personas que habita por vivienda está entre 5 y 7 personas; el sector con mayor densidad poblacional con 428 habitantes es el dos; le sigue el sector tres con 238 y por último el sector uno con 62 habitantes. ${ }^{64}$

Según La encuesta aplicada por la alcaldía las características del sistema sanitario de eliminación de excretas son $88.5 \%$ a través de fosa o pozo séptico, un $9.9 \%$ usan letrinas y $1 \%$ tiene una conexión fosa directa al vallado. En cuanto al mantenimiento de este sistema sanitario que en el caso de los pozos se debe hacer a través de un vactor el $75.6 \%$ no lo realiza y solo un 24.4 si lo hace. ${ }^{65}$

\footnotetext{
${ }^{63}$ Base de datos, 2005.

${ }^{64}$ Alcaldía Local de Suba, 2009

${ }^{65}$ Ibíd.
} 


\section{OBJETIVOS}

\section{Objetivo General}

Análisis de la contribución de los sanitarios secos al saneamiento básico rural. El caso de la Vereda Chorrillos.

\section{Objetivos Específicos}

- Identificar las características socio-ambientales del sistema alternativo de saneamiento básico de baños secos en la Vereda Chorrillos.

- Evaluar los baños secos como alternativa de saneamiento básico para zonas rurales.

- Determinar los elementos de gestión ambiental, en las alternativas de saneamiento básico específicamente en baños secos para zonas rurales.

\section{METODOLOGIA}

Para los fines de esta investigación se propuso desarrollar una metodología desde el enfoque cualitativo, con una estrategia de investigación de estudio de caso complementada con observación participante, después de la recopilación de información y un reconocimiento del área de investigación, se desarrolló una fase de campo apoyada por instrumentos como, la entrevista a grupo focal e informantes claves, para así validar e interpretar los datos recolectados y posteriormente concluir los aportes de los mismo. 
Desde el enfoque cualitativo, la realidad social es el resultado de un proceso interactivo en el que participan los miembros de un grupo para negociar y renegociar la construcción de la realidad. ${ }^{66}$

El método cualitativo busca conceptualizar sobre la realidad con base en los conocimientos, las actitudes y los valores que guían el comportamiento de las personas estudiadas, este no parte de supuestos derivados teóricamente. El proceso de investigación cualitativa explora de manera sistemática los conocimientos y valores que comparten los individuos en un determinado contexto espacial y temporal. ${ }^{67}$

Además permite desarrollar una comunicación directa permanente con los sujetos investigados, porque su interés implica de hecho comprender el conocimiento que ellos tienen de su situación y de sus condiciones de vida. Por otro lado los métodos cualitativos son más abiertos, flexibles y consideran todas las observaciones anotadas como datos potenciales que deben decantar en forma sistemática. ${ }^{68}$

\subsection{Enfoque}

La hermenéutica se ha conocido como la labor interpretativa, su origen es de amplia tradición griega; el verbo hermeneuein, expresa con claridad la acción de interpretar Es así como los hermeneutas buscan descifrar la realidad social de forma particular a través de un proceso de reconstrucción psicológica, por lo tanto el texto es la expresión de los sentimientos, pensamientos y comportamientos de quien lo realiza. ${ }^{69}$

\footnotetext{
${ }^{66}$ Watson, 1991en Bonilla et al, 1997 pag 55.

${ }^{67}$ BONILLA-CASTRO. Elssy. RODRIGUEZ-SEHK. Penélope. Más allá del dilema de los métodos: La investigación ciencias sociales. Grupo editorial norma. Colombia. 1997, segunda edición uniandes 1997. Pág. 220.

${ }^{68}$ Ibíd.

${ }^{69}$ LÓPEZ PARRA. Hiader Jaime. Investigación Cualitativa Y Participativa: Un Enfoque Histórico-Hermenéutico Y Crítico-Social En Psicología Y Educación Ambiental. Universidad Pontificia Bolivariana. Medellín. 2001. 220 pág.
} 
De esta forma, se comprende que la hermenéutica implica, como enfoque de investigación, una labor a través de la cual el investigador busca comprender e interpretar un fenómeno o realidad en un contexto concreto, donde se debe integrar lo espacial, los actores y la cultura, abordados en los siguientes párrafos.

Como lo menciona Fabio lozano en su ensayo Aspectos Constitutivos De Una Hermenéutica Activa, lo espacial, geográfico que es todo el conjunto de condiciones físico ambientales que inciden en la caracterización de los comportamientos de los seres humanos como individuos deben ser tenidos en cuenta para una comprensión acertada de los fenómenos. ${ }^{70}$

De otro lado el contexto se refiere a las condiciones de relación de diferentes actores que participan con mayor o menor protagonismo y conciencia. Igualmente el contexto tiene aspectos culturales que se refieren tanto a los usos y costumbres como a las mentalidades y valoraciones. ${ }^{71}$

Por lo anterior se considera que la hermenéutica se ha propuesto como una manera de concebir el desarrollo del conocimiento ${ }^{72}$, aporte fundamental para la realización de este trabajo de investigación.

Por último este párrafo mencionado por Lozano en su ensayo se acerca a la realidad que deben construir muchas comunidades entre ellas la Vereda Chorrillos como auto gestoras de su desarrollo. "La historia se individualiza y se particulariza por el hombre concreto que la realiza y que la vive. Es decir, que el hombre se comprende a sí mismo no simplemente comprendiendo la historia del pasado, sino al vivir su propia historia en una radical experiencia de sí mismo, de su mundo, de sus situaciones, circunstancias, cautividades y empeños por la liberación. Y no se trata de que el

\footnotetext{
${ }^{70}$ Lozano V, Fabio. Polifonía en desarraigo mayor. Mentalidades religiosas, desplazamiento forzado y violencia socio política en Colombia a fines del s. XX. Tesis doctoral. Capítulo Hermenéutica Activa. Toulouse le Mirail. 2002

${ }^{71}$ Ibíd.

${ }^{72}$ Ibíd.
} 
hombre y las comunidades primero interpreten y después actúen, sino de que se auto interpreten como gestores y realizadores de su propia historia e historicidad en la acción transformadora, original $e$ inédita de sus propios compromisos $y$ responsabilidades". ${ }^{73}$

\subsection{Estrategia De Investigación}

Estudio de caso: Se considera una herramienta valiosa de investigación, y su mayor fortaleza radica en que a través del mismo se mide y registre la conducta de las personas involucradas en el fenómeno estudiado.

Respecto a su propósito, las investigaciones realizadas a través del método de estudio de caso pueden ser: descriptivas, si lo que se pretende es identificar y describir los distintos factores que ejercen influencia en el fenómeno estudiado, y exploratorias, si a través de las mismas se pretende conseguir un acercamiento entre las teorías inscritas en el marco teórico y la realidad objeto de estudio. ${ }^{74}$

De allí que Eisenhardt (1989) conciba un estudio de caso contemporáneo como "una estrategia de investigación dirigida a comprender las dinámicas presentes en contextos singulares". ${ }^{75}$

\footnotetext{
${ }^{73}$ Ibíd.

${ }^{74}$ MARTINEZ. Piedad Cristina Martínez. El método de estudio de caso. Estrategia metodológica de la investigación científica. Mayo de 2006. http://ciruelo.uninorte.edu.co/pdf/pensamiento_gestion/20/5_El_metodo_de_estudio_de_caso.pdf

${ }^{75}$ Ibíd.
} 
Observación participante: Es un método utilizado por los antropólogos para "sumergirse" durante largos tiempos en la vida diaria de la comunidad para entenderla mejor. Aquí se trata de una forma más superficial: participar directamente en algunas actividades de la gente, para adquirir una comprensión más profunda, y producir comentarios e informaciones en forma más oportuna y espontánea. ${ }^{76}$

Una de las estrategias claves para recopilar información acerca de las cuatro familias pertenecientes al proyecto piloto fue la observación directa en su diario vivir, esta se realizó con visitas periódicas a sus viviendas durante un año y a diferentes horas del día.

El acercamiento permitió de manera detallada ver diferentes aspectos respecto al uso y mantenimiento de los sanitarios secos, las prácticas más comunes, como estaba involucrada la familia con el nuevo sistema, quienes eran los usuarios más frecuentes y las experimentaciones que hacían respecto a la disposición del material secante, y elaboración del abono.

Este acercamiento permitió establecer algunas particularidades en cada una de las familias como, por ejemplo el responsable de delegar las tareas respecto a la unidad la apropiación de la familia para hablar del sistema al recibir grupos interesados en conocer experiencia. Las familias socializaron datos interesantes de la observación y convivencia diaria con el sistema, como la forma de tomar la temperatura en el tanque y en el abono, como registran los datos y los experimentos empíricos sobre la aplicación de la orina como fertilizante en sus parcelas. Esta estrategia permitió evidenciar la relación de algunos conceptos desarrollados en la investigación como desarrollo,

\footnotetext{
${ }^{76}$ BONILLA-CASTRO. Elssy. RODRIGUEZ-SEHK. Penélope. Más allá del dilema de los métodos: La investigación ciencias sociales. Grupo editorial norma. Colombia. 1997, segunda edición uniandes 1997. Pág. 220.
} 
desarrollo sostenible y calidad de vida con el estudio de caso de la Vereda Chorrillos los cuales serán analizados y discutidos más adelante.

\subsection{Técnicas E Instrumentos}

Entrevista a informantes clave: No es un método participativo propiamente dicho, pero puede ser imprescindible para preparar ejercicios de grupo con la comunidad, antes de la intervención, y también para completar otros ejercicios o chequear ciertas informaciones: dialogando con personas bien informadas sobre la comunidad, se puede obtener en forma rápida informaciones pertinentes para orientar el trabajo. La buena selección de los informantes es fundamental para la validez de la información. ${ }^{77}$

Estas entrevistas se realizaron a personas importantes, relacionadas en el proceso de los sanitarios secos en la vereda, entre ellos están tres técnicos en saneamiento ambiental encargados de realizar los seguimientos y acompañar a la familia en el proceso de adaptación, al igual que reforzar algunos temas técnicos dentro del mismo y fijar compromisos con tiempos de cumplimiento establecidos por mutuo acuerdo con las familias.

Otra elemento de gran importancia, ha sido la Trabajadora Social que ha estado involucrada con la familia desde el inicio del proyecto y su trabajo se ha basado, en primer lugar, hacer una selección de las familias beneficiadas del proyecto, asesorar y capacitar a la familia en el manejo del sistema, reforzar hábitos higiénico-sanitario, mejorar el entorno de la vivienda, el lavado de manos entre otros. Un segundo momento fue el posicionamiento del proyecto y la socialización de la experiencia con instituciones y otras familias de la vereda con el fin de lograr dar a conocer los beneficios y animar a otros habitantes a construir sus sanitarios secos por autogestión.

\footnotetext{
${ }^{77}$ BONILLA-CASTRO. Elssy. RODRIGUEZ-SEHK. Penélope. Más allá del dilema de los métodos: La investigación ciencias
} sociales. Grupo editorial norma. Colombia. 1997, segunda edición uniandes 1997 
Por último el Administrador ambiental encargado de la coordinación del proyecto aunque su participación fue después del diseño e instalación de los sanitarios secos, su labor fue dar continuidad a los compromisos adquiridos por el Hospital de Suba con las familias beneficiadas, buscando alternativas de disposición del biosólido deshidratado, la orina almacenada por separado y el posicionamiento del proyecto con actores institucionales y sociales.

Los resultados de estas entrevistas fueron organizados en la matriz de análisis de datos cualitativo, según las categorías de análisis propuestas, como insumo para la consolidación de los resultados y la discusión de los mismos.

Grupo Focal: Es un medio para recolectar, en poco tiempo y en profundidad, un volumen significativo de información cualitativa, a partir de una discusión con un grupo de seis o doce personas, que son guiados por un entrevistador para exponer sus conocimientos y opiniones sobre temas considerados importantes para el estudio. Este tipo de entrevistas constituyen una fuente importante de información para comprender las actitudes, las creencias, el saber cultural y las percepciones de una comunidad en relación con algún aspecto particular del problema de investigación. ${ }^{78}{ }_{-} 79$

El grupo focal estuvo conformado por seis habitantes de la vereda, dos por cada sector, tres de ellos eran beneficiarios del proyecto, uno está construyendo su sanitario seco por autogestión y las otras dos personas utilizan el sistema convencional de pozo séptico. En un primer momento se socializa el objetivo de la investigación y se les invita a las mesas de trabajo, las cuales se organizaron en el sector dos de la vereda con una frecuencia de encuentro de cada quince días durante seis meses. Se abordaron herramientas como árbol de problemas con el fin de conocer a fondo la problemática socio-ambiental de la vereda, y se trabajaron temáticas como recursos hídricos, manejo de aguas grises y negras, sistemas convencionales y el sistema alternativo de sanitarios secos.

\footnotetext{
${ }^{78}$ Ibíd.

${ }^{79}$ Ver anexo fotográfico 3
} 
Entrevista Semi-estructurada: Se centra en el conocimiento o la opinión individual solo en la medida en que dicha opinión puede ser representativa de un conocimiento cultural más amplio. Se realiza a través de un listado de preguntas guía. ${ }^{80}$

Se realizaron seis entrevistas individuales semi-estructuradas, dos por cada uno de los sectores de la vereda con personas de diferentes edades y que no están involucradas al proyecto piloto, la duración de la entrevista fue aproximadamente de una hora, donde se propició un diálogo en con los informantes apoyado por preguntas guías las cuales abordaba las problemáticas socio-ambientales de la zona, el sistema que utilizaban en sus viviendas las ventajas y desventajas de los mismos, posterior a esto se indagaba acerca de los sanitarios secos y su aporte al desarrollo de zonas rurales como la Vereda Chorrillos.

La información recopilada tanto del grupo focal como de las entrevistas semiestructuradas fue plasmada en la matriz de análisis de datos cualitativos en la columna de percepción de la comunidad.

\section{VALIDACIÓN DE LA INFORMACIÓN}

Organización y análisis de la información recogida y posteriormente retroalimentación a la comunidad de los resultados obtenidos mediante reuniones de socialización.

${ }^{80}$ Ibíd. 


\section{FASES DEL PROCESO DE INVESTIGACIÓN}

\section{FASE 1: DIAGNÓSTICO}

- Recopilación de información: fuentes secundarias sobre la zona, experiencias de sanitarios ecológicos.

- Identificación del área de estudio: Realizar un recorrido por la zona de estudio, identificando los actores involucrados, presentación de la propuesta a la comunidad.

\section{FASE 2: TRABAJO DE CAMPO}

- Identificación de los grupos de trabajo representativos de los diferentes actores presentes en la zona.

- Recolección de la información por medio de Los instrumentos arriba mencionados. ${ }^{81}$

\section{FASE 3: PROCESAMIENTO Y ANALISIS}

En esta fase se hizo toda la evaluación y consolidación del material producto de cada una de las actividades, para dar los resultados pertinentes y empezar la consolidación del documento final.

\footnotetext{
${ }^{81}$ Ver anexos 1 y 2.
} 
DIAGRAMA DE FLUJO DEL PROCEDIMIENTO

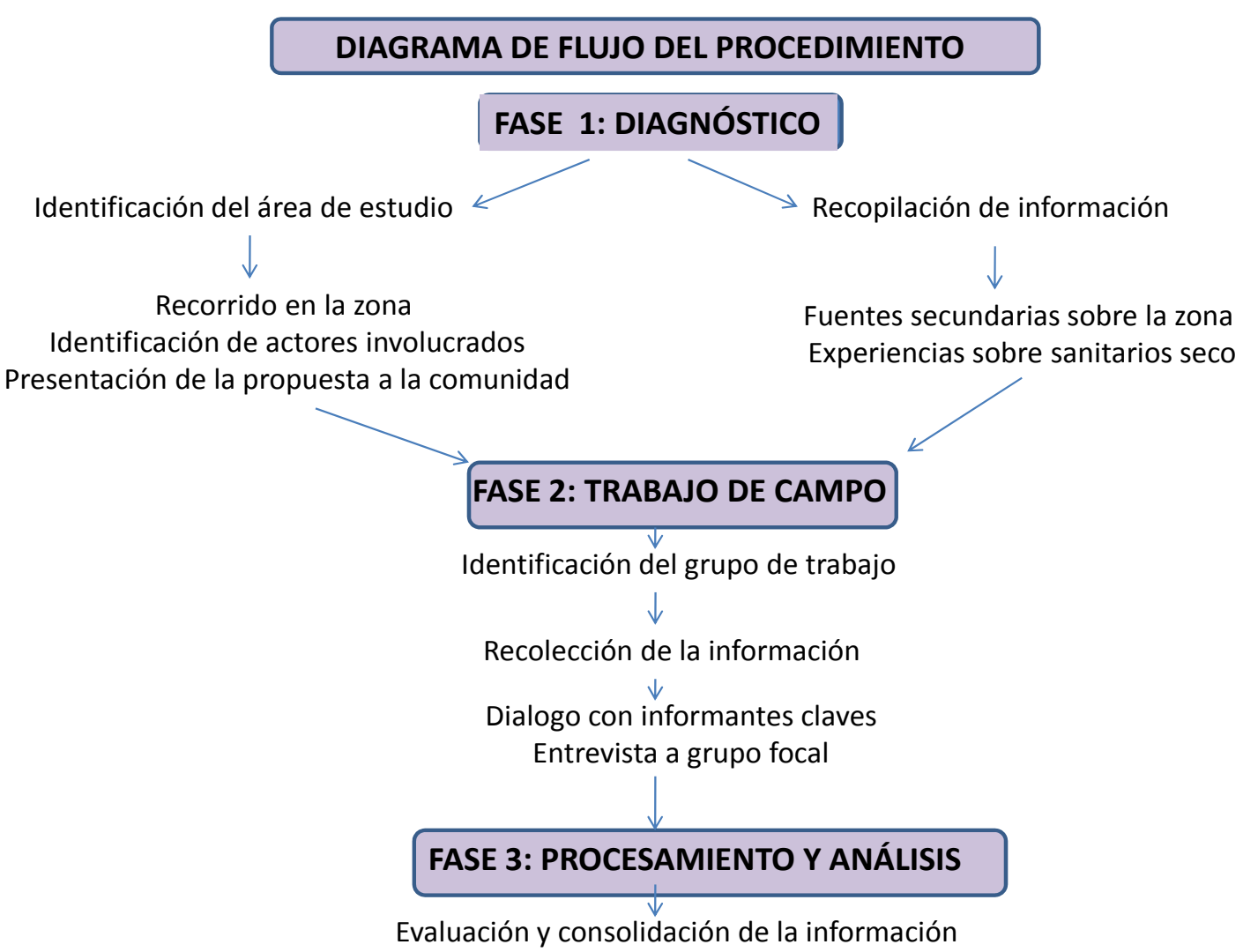




\section{RESULTADOS Y DISCUSIÓN}

El presente capitulo da respuesta a los objetivos planteados en esta investigación a partir de la información arrojada por las entrevistas e información recopilada durante la fase de campo.

\subsection{Características socio-ambientales del sistema alternativo de saneamiento básico de baños secos en la vereda chorrillos.}

\section{Sociales:}

- Dignifica a las familias. El componente social es la parte más fuerte del proyecto, ya que es un proceso constante con las familias, inicialmente se trabajó con talleres y después se realizo un acompañamiento casi que diario para que ellos conocieran el sistema, rompieran algunas barreras frente a su mantenimiento y lo hicieran parte de sus labores diarias, ellos lo vieron como una oportunidad para mejorar su calidad de vida, como disminuir la contaminación de los aljibes.

- Posterior a este trabajo el acompañamiento se hizo con lapsos de tiempo mayores para que ellos se apropiaran del proceso y en cada visita se dejaban compromisos y se reforzaban las temáticas que se necesitara. Ahora los seguimientos son esporádicos, casi siempre se visitan con el fin de mostrar la experiencia a otras personas.

- La labor que se ha realizado con esta comunidad ha permitido evidenciar una fuerte motivación a trabajar en equipo y a fortalecer las redes sociales. El interés aumenta cuando se tratan temas que apuntan a la resolución de las problemáticas mencionadas anteriormente, como la apropiación del 
territorio, temáticas sobre resolución de conflictos ambientales, valores y saberes campesinos, o formas asociativas de trabajo.

- A partir de la implementación de un sanitario seco se evidencian cambios de hábitos que trascienden del baño, como motivación para el mejoramiento de vivienda, mejorar condiciones sanitarias por disminución de olores o regurgitación de aguas servidas, así mismo tanto en la comunidad como en la familia se ha dado una redefinición de roles y a fomentado la responsabilidad de ciertas acciones como es la de hacernos cargo de nuestros residuos.

- Otro punto importante es que el desarrollo del sistema de sanitarios secos ha impulsado nuevos conocimientos en las familias beneficiarias como la experimentación con la adición de orina y de bocashi a los suelos, y los preparados naturales que le aplican la tanque del biosólido con el fin de mitigar olores. Al reconocerse como población campesina, el hecho de realizar abonos o fertilizantes que pueden usar dentro de sus predios, ha aumentado el interés y compromiso por hacer el mantenimiento y tratamiento debido tanto al sanitario como al biosólido (excreta humana deshidratada) que se produce.

- La experiencia de este proyecto piloto ha demostrado que el trabajo en equipo e integrado con la familia ha permitido la adaptación de las mismas a este sistema desconocido por muchos, ellos han integrado el uso de este como una práctica común e incluso han impulsado a otros a que construyan y dejen a un lado el sistema convencional, así mismo ellos se han convertidos en impulsores de este proyecto dándolo a conocer y explicando el sistema a las personas que los visitan de otras localidad o entidades. 


\section{Ambientales:}

- El sistema no necesita requerimiento de agua para su funcionamiento lo cual evita la contaminación directa a las cuencas o a los pozos o aljibes, a los suelos y disposición de excretas a campo abierto.

- Entre los beneficios de los sanitarios secos, es que evita la proliferación de vectores y olores y lo consideran una solución a la falta de alcantarillado en la zona.

- Las familias beneficiarias del proyecto manifiestan que la presencia de enfermedades como la diarrea ha disminuido considerablemente, al igual síntomas como nauseas o dolores de cabeza que eran producidos por los malos olores emitidos de los pozos.

- Al no necesitar conexiones hidráulicas se genera ahorro en la cantidad de agua usada para la eliminación de excretas y por consiguiente disminuye la carga orgánica contaminante en los afluentes más cercanos.

- Se realiza un aporte de nutriente al suelos a través del bocashi y la orinaza (abono realizado a partir del biosólido y la orina), el cual puede actuar como un excelente recuperador de suelos.

- Se integra a los ciclos biológicos nutrientes importantes que ayudan al equilibrio ecosistémico de las zonas.

- Mitiga impactos negativos ambientales causados en zonas rurales como es el caso de la vereda Chorrillos por la ausencia de servicios domiciliarios (acueducto y alcantarillado).

- Mejora las condiciones de salubridad del agua que utilizan para consumo los habitantes de la vereda, que es proveniente de pozos o aljibes. 


\subsection{Los baños secos como alternativa de saneamiento básico para zonas rurales.}

Los sanitarios secos han sido implementados en diferentes países con el fin de abordar diversas problemáticas tanto sociales como ambientales se han constituidos como una propuesta sostenible para diversas regiones y han logrado reivindicar el actuar de hombre frente a la naturaleza, mitigando los impactos generados por nuestros procesos de "desarrollo" y retribuyendo un poco al ambiente todo lo que nos ha ofrecido y que le hemos quitado.

Algunas de las contribuciones de este sistema se pusieron en evidencia, en el seguimiento en campo que se realizo al proyecto piloto del Hospital de suba en la vereda Chorrillos donde la percepción y las dinámicas familiares de los beneficiados demostraron que es un sistema viable para zonas rurales con problemáticas similares (falta de alcantarillado y acueducto) y para zonas urbanas donde se busque minimizar impactos ambientales.

\section{Construcción}

El tipo de construcción de los sanitarios secos puede varias según el modelo que se quiera, ya sea la interior de la vivienda o fuera de ella; para el caso del proyecto piloto de la Vereda Chorrillos están ubicadas fuera de la viviendas, estos cuentan con una estructura que permite en cualquier momento desmontarla, trasladarla y además es resistente a ciertos factores como la humedad. La vida útil de este sistema depende del material que se escoja para su construcción y del mantenimiento que se le haga.

Para el caso de los sanitarios que se están construyendo por autogestión varia el diseño (doble cámara), ya que se encuentran al interior de la vivienda, lo cual permite una vida útil mayor que el sistema en exteriores. Los materiales que se pueden usar y los costos aproximados se observan en la siguiente tabla: 
TABLA DE MATERIALES

\begin{tabular}{|c|c|c|}
\hline \multirow{24}{*}{$\begin{array}{c}\text { SANITARIO SECO AL EXTERIOR } \\
\text { DE LA VIVIENDA MODELO } \\
\text { HOSPITAL DE SUBA }\end{array}$} & ITEM & $\begin{array}{c}\text { COSTO } \\
\text { APROXIMADO }\end{array}$ \\
\hline & 1. ESTRUCTURA & \multirow{23}{*}{$\$ 1.500 .000$} \\
\hline & Perfiles de acero & \\
\hline & 2. CERRAMIENTO & \\
\hline & Fibrocemento (superboard) & \\
\hline & \begin{tabular}{|l} 
Vigas de hierro \\
\end{tabular} & \\
\hline & Tejas/ TECHOLINE & \\
\hline & Tornillo + Arandela + Tuerca & \\
\hline & 2. TUBERÍAS CONDUCCIÓN Y & \\
\hline & \begin{tabular}{|l|} 
DESAGUES \\
Manguera Orina
\end{tabular} & \\
\hline & 3. DISPOSITIVOS DE AGUA Y & \\
\hline & SANEAIVIENTO & \\
\hline & orina & \\
\hline & Orinal & \\
\hline & 4. TANQUES DE ALMACENAMIENTO & \\
\hline & $\begin{array}{l}2 \text { Tanques cilíndricos plásticos negros } \\
\text { para Excreta } 250 \text { Its. }\end{array}$ & \\
\hline & 1 Galon plástico de 25 Lts & \\
\hline & 6. ACCESORIOS & \\
\hline & Porta papel higiénico & \\
\hline & Tapetes antideslizantes & \\
\hline & Escaleras con barandas & \\
\hline & Letreros identificativos en acrilico & \\
\hline & Carteles de uso adecuado & \\
\hline & MANO DE OBRA & \\
\hline \multirow{17}{*}{$\begin{array}{l}\text { SANITARIO SECO CONSTRUIDO } \\
\text { AL INTERIOR DE LA VIVIENDA }\end{array}$} & 1. ESTRUCTURA & \multirow{17}{*}{$\begin{array}{c}\$ 2.300 .000 \mathrm{a} \\
\$ 2.800 .000\end{array}$} \\
\hline & Ladrillos & \\
\hline & Cemento & \\
\hline & Enchape & \\
\hline & Boquilla & \\
\hline & Taza separadora & \\
\hline & Orinal & \\
\hline & Compuertas hermeticas & \\
\hline & Lavamanos & \\
\hline & Puerta para baño & \\
\hline & 2. ACCESORIOS & \\
\hline & Toallero & \\
\hline & Porta papel higiénico & \\
\hline & Tapetes antideslizantes & \\
\hline & Letreros identificativos en acrilico & \\
\hline & Carteles de uso adecuado & \\
\hline & MANO DE OBRA & \\
\hline
\end{tabular}




\section{Funcionamiento}

La separación de la excreta y la orina a través de la taza separadora permite que se haga un aprovechamiento de ambos residuos como fertilizantes o abonos orgánicos y que su manejo sea bastante fácil, después de cada defecación se debe adicionar un material secante que puede ser ceniza, tierra seca, bocashi, aserrín. Frente a la presencia de olores o de moscas, reconoceremos estos como síntomas de alerta, que indica que se debe reforzar o aumentar la cantidad de material secante, en algunos casos las familias han experimentado la adición de preparados a base de hierbas maceradas como es el caso de la ruda, ajo y caléndula que ayuda a mitigar los olores provenientes del tanque. Este es el punto clave del mantenimiento ya que en algunos casos la presencia de olores o moscas puede generar rechazo hacia el sistema.

El tanque de la excreta una vez esta lleno se retira y se deshidrata por un periodo de tres meses sobre una estiba de madera, ya que el contacto con el suelo pude aumentar la humedad, se debe cubrir por una lona, que permite que el material respire y de vez en cuando se realiza volteo del biosólido dentro del mismo tanque con ayuda de una pala. Posterior a esto ya se debe hacer un manejo de este subproducto.

Para el caso del biosólido (excreta humana deshidratada), nombre que se le da a las excretas por las familias que tiene el sistema, ya permite pensar en una trasformación cultural de ver la excreta no como un residuo sino como un producto. Se utiliza como materia prima para la elaboración de Bocashi (abono orgánico), esta técnica enseñada por el IICA. El cual se prepara en un sitio especial (compostera) aislada de la vivienda con una estructura en madera recubierta en plástico de alta densidad, utilizando materiales como pasto de corte seco y triturado, boñiga de vaca fresca (no mayor a tres días), melaza, salvado o cascarilla de arroz, tierra, biosólido, agua, se empieza a formar capas de cada uno de los componentes hasta formar un nivel de capas sobrepuestas o sanduche, y posterior a esto se realiza una mezcla de todo con ayuda de una pala. El material se dispone en forma de pila, se cubre con un 
costal y la temperatura empieza a aumentar desde 45 hasta que alcanza 60 grados, lo que permite la muerte de los parásitos. Estos datos son tomados por los integrantes de las familias con ayuda de una termocupla y diligenciados en formatos que ellos mismos manejan, después de 30 días se obtiene abono orgánico. ${ }^{82}$

Una vez se obtiene el abono orgánico tratado mediante el compostaje se puede aplicar a cultivos ornamentales que permita aportar al suelo nutrientes y contribuir de cierta manera en los ciclos biogeoquímicos. Es importante anotar que inicialmente y bajo el principio de precaución el biosólido no se aplica en cultivos donde haya un contacto directo con el suelo como es el caso de las hortalizas para evitar riesgo que se pueda generar en la salud pública.

Durante las entrevistas con informantes claves se conoció la prueba experimental del abono, aplicado mediante bloques completamente al azar en parcelas dividas en cultivos de la flor "Estrella de Belén". Donde se recolectaron los datos de las variables: Diámetro y altura del tallo y el botón de la flor. Donde a través de un análisis estadístico se determino la eficiencia del abono aplicado. De acuerdo a lo manifestado por cultivadores de estrella de belén, el bioabono aplicado mejoró en: el tallo incremento su color verde, el diámetro y el período de producción del suelo se incremento entre dos y cinco meses.

Por otro lado al llenado del tanque de la orina, los integrantes de la familia lo retiran y diluyen con cuatro partes de agua por una de orina y usarla como fertilizante (orinaza). Algunos de los integrantes de las familias han hecho parcelas demostrativas y han tomado nota de los cambios que observan, y manifiestan que con la orinaza el pasto de torna más verde y su altura es mayor, aunque para cualquier afirmación de la eficiencia de este fertilizante se hace necesario hacer un estudio comparativo más profundo sobre las bondades del mismo.

\footnotetext{
${ }^{82}$ Ver anexos fotográficos 3
} 


\section{Aceptabilidad cultural}

Algunos integrantes de las familias especialmente las mujeres manifestaron que al principio es difícil usarlo pero después se acostumbran, especialmente en la postura que se debe tener al usar la taza para evitar filtraciones de orina en el tanque de la excreta. En algunas ocasiones es molesto cuando sienten mal olor, pero esto les permite saber que algo está fallando y le adicionan más material secante para que el olor se pase. Los niños son personas claves en el establecimiento de este sistema, ellos deben comprender como funciona bien el baño, sino no tienen el cuidado necesario en el momento de utilizarlo.

A pesar de que necesita tiempo para su mantenimiento han mejorado los alrededores de las vivienda y reforzado algunas costumbres como el lavado de las manos. Es necesario que todos en la familia colaboren porque sino la carga la lleva una sola persona y eso genera agotamiento y desinterés frente al sistema, pero si se le incentiva a la familia que debe estar unida y que todos deben aportar se logra adaptarse con mayor facilidad al sistema.

Durante las observaciones de campo se evidencia que el manejo de este sanitario es algo ya familiar para ellos y que han accedido a un sistema más digno e higiénico para su uso ${ }^{83}$, en dos de las casa la familia decidió tumbar el baño convencional que está conectado al pozo séptico y usar solamente el sanitario seco. Incluso los vecinos que han conocido el sistema han manifestado el interés de tenerlo, esto ha generado que tres familias estén construyendo sus sistemas por autogestión, recursos propios apoyados en la asesoría técnica que prestan los técnicos ambientales del Hospital de Suba.

\footnotetext{
${ }^{83}$ Ver anexo fotográfico 2 Y 3
} 


\section{Económicos}

La implementación de sanitarios secos, puede ser una oportunidad de creación de empresas comunitarias para el manejo y apoyo de labores como la construcción, funcionamiento y mantenimiento de los sanitarios secos en caso de su masificación. El abono se ha convertido para algunos en una fuente de ingreso lo comercializan con vecinos o familiares, pero la producción de este no es constante ya que depende del tiempo en que los tanques se llenen y se haga el proceso de compostación.

Este sistema permite autonomía en la parte económica ya que no es necesaria la conexión a redes de alcantarillado lo cual acarrea un costo mensual por el servicio, además podría incentivar a la creación de empresas comunitarias que se encarguen de la recolección y tratamiento del biosólido de las familias que no lo quieran procesar.

En cuanto a la empresa privada es una buena propuesta por que la fabricación de los accesorios para estos baños es escasa en el país y se podría generar un nuevo mercado si estos sistemas se masificaran en las regiones con problemáticas similares, y permitiría crear diseños nuevos con lo cual se podría entrar a mercados internacionales. Además se deben crear incentivos económicos para su implementación por parte del estado y promover una mayor inversión de la empresa privada.

Algunas de las desventajas pueden ser el desconocimiento del sistema para su uso y mantenimiento, un costo inicial alto lo cual dificultaría la masificación de la experiencia con recursos propios. La construcción requiere mayor conocimiento técnico, se puede presentar resistencia al cambio de tecnología por parte de las personas, adaptabilidad progresiva, requiere mayor estudio el manejo del biosólido y la orina, requiere espacio para el manejo de la excreta deshidratada.

Sin embargo se puede constituir como una propuesta sostenible que no causa impacto ambiental y económicamente es viable, que debe estar acompañada con un 
programa donde se esté en constante trabajo con la familia para que se permita la aceptación y apropiación del sistema y este no genere por el contrario un rechazo o impacto mayores ante su utilización.

Como es el caso de los pozos séptico que para los habitantes de la zona el pozo es un hueco cavado a mano revestido de materiales como cemento, o piedra que no necesita mayores conocimientos técnicos para su construcción, debido a su fácil construcción y a la facilidad de los recursos usados, el pozo es el medio más utilizado, aunque realiza un alto aporte de materia orgánica al suelo que puede ser arrastrado al Río por la lluvia, no se hace un aprovechamiento de los residuos sólidos, el mantenimiento de este sistema es costoso y solo plantea dos alternativas desocuparlos a través de un carros especial llamado vactor, el cual cobra por pozos desocupado $\$ 280.000$,o hacerlo manualmente con un balde lo cual es riesgoso para la salud de la persona que haga la manipulación del mismo, o sellarlo una vez se haya llenado y construir otro lo cual requiere recursos y espacio dentro de la vivienda. 


\subsection{Elementos de gestión ambiental, en las alternativas de saneamiento básico específicamente en baños secos para zonas rurales.}

Los elementos de gestión ambiental en las alternativas de saneamiento básico específicamente baños secos para las zonas rurales es necesario mencionar los actores sociales que hacen parte del territorio y las herramientas e instrumentos de gestión que se deben tener en cuenta para formular y desarrollar, planes, programas o proyectos tendientes a mejorar la calidad de vida de una comunidad en el ámbito socioambiental como es el caso de la Vereda Chorrillos.

\section{Actores}

En el siguiente cuadro se identificaron los actores principales tanto comunitarios como institucionales que hacen presencia en la Vereda Chorrillos, resaltando sus funciones y responsabilidades de acuerdo a las competencias otorgadas por la Ley.

Estos actores serán los responsables de generar cambios en el territorio frente a las propuestas de saneamiento básico alternativo, los actores comunitarios serán los encargados de promover y fortalecer los procesos dinamizadores dentro de su comunidad, apoyados por los actores institucionales quienes son los responsables de ejecutar las políticas del Gobierno Nacional, además de ser entes reguladores a nivel ambiental, social, y de salud entre otros. 


\begin{tabular}{|c|c|c|c|c|}
\hline \multicolumn{3}{|c|}{ ACTORES SOCIALES } & \multirow[b]{2}{*}{\begin{tabular}{|l|}
\multicolumn{1}{|c|}{ FUNCIONES } \\
La acción comunal, es una expresión social organizada, \\
autónoma y solidaria de la sociedad civil, cuyo propósito es \\
promover un desarrollo integral, sostenible y sustentable \\
construido a partir del ejercicio de la democracia participativa \\
en la gestión del desarrollo de la comunidad. Ley 743 de 2002. \\
Titulo Segundo. Capitulo I. Art. 6
\end{tabular}} & \multirow[b]{2}{*}{$\begin{array}{l}\text { RESPONSABILIDADES } \\
\text { Promover y fortalecer en el individuo, el sentido de pertenencia frente a su } \\
\text { comunidad a través del ejercicio de la democracia participativa; Planificar el } \\
\text { desarrollo integral y sostenible de la comunidad. Generar procesos } \\
\text { comunitarios autónomos de identificación, formulación, ejecución, } \\
\text { administración y evaluación de planes, programas y proyectos de desarrollo } \\
\text { comunitario. Ley } 743 \text { de 2002. Titulo Segundo. Capitulo I. Art. } 6\end{array}$} \\
\hline \multirow{4}{*}{ ACTORES COMUNITARIO } & \multirow{4}{*}{ VEREDALES } & JUNTA DE ACCIÓN COMUNAL & & \\
\hline & & FUNDACIÓN SURCOS VERDES & $\begin{array}{l}\text { Asociación de los Campesinos de la Vereda Chorrillos } \\
\text { productores de hortalizas organicas. }\end{array}$ & $\begin{array}{l}\text { Comercialización de los productos organicos de la zona. Pormoción de los } \\
\text { estandares de producción orgánica. }\end{array}$ \\
\hline & & ASOCIACION AGUAS DEL CAMPO & $\begin{array}{l}\text { Asociación de la Comunidad de la Vereda Chorrillos para la } \\
\text { administración del recurso hidrico de la zona. }\end{array}$ & $\begin{array}{l}\text { Administrar el acueducto veredal una vez la Alcaldia lo financie, velar por su } \\
\text { buen funcionamiento, garantizar la distribución del recurso y manejo del } \\
\text { mismo para toda la comunidad, cumplir con las normas ambientales y } \\
\text { sanitarias, implementar el programa de ahorro y uso eficiente del recurso } \\
\text { hidrico (Ley 373/97), reportar a la Autoridad Ambiental anualmente los }\end{array}$ \\
\hline & & ASODESCO & $\begin{array}{l}\text { Esta conformado por un grupo de vecinos que reside en el } \\
\text { norte de la ciudad, y agrupados en la Asociación para el } \\
\text { Desarrollo Integral de la Zona de Influencia de la Vía Suba- } \\
\text { Cota (Asodesco). Además hacen parte de la Comision } \\
\text { Ambiental Local. }\end{array}$ & $\begin{array}{c}\text { Velar por el ordenamiento territorial de la zona norte y garantizar los derechos } \\
\text { adquiridos en la misma. Velar para que la normatividad ambiental existente se } \\
\text { ejecuten de acuerdo a la realidad del territorio. }\end{array}$ \\
\hline \multirow{9}{*}{$\begin{array}{l}\text { ACTORES } \\
\text { INSTITUCIONALES }\end{array}$} & NACIONAL & $\begin{array}{c}\text { INSTITUTO INTERAMERICANO DE } \\
\text { COOPERACIÓN PARA LA } \\
\text { AGRICULTURA }\end{array}$ & $\begin{array}{l}\text { Desarrolla acciones de cooperación en asuntos considerados } \\
\text { como críticos para el sector agrícola y el medio rural, aportando } \\
\text { sus capacidades técnicas y gerenciales, su infraestructura y } \\
\text { enfoque interamericano. }\end{array}$ & $\begin{array}{c}\text { Actua a través de la construcción de alianzas y la ejecución de proyectos de } \\
\text { desarrollo enmarcados en la Agenda Nacional de Cooperación Técnica, } \\
\text { teniendo siempre como meta el desarrollo de la agricultura y las comunidades } \\
\text { rurales del país. } \\
\text { http://www.iica.int/Esp/regiones/andina/colombia/Paginas/default.aspx }\end{array}$ \\
\hline & DEPARTAMENTAL & $\begin{array}{l}\text { CORPORACION AUTONOMA } \\
\text { REGIONAL. CAR }\end{array}$ & $\begin{array}{l}\text { Garantizar la distribución y manejo de los recursos naturales de } \\
\text { forma equitativa entre los habitantes del territorio. Generar } \\
\text { proceso de cambio en los hábitos de las personas, } \\
\text { comunidades y organizaciones, dando lugar a una sociedad en } \\
\text { donde la razón de ser de su existencia es el valor colectivo de } \\
\text { la preservación del ambiente. }\end{array}$ & $\begin{array}{l}\text { Ejecutar las Políticas establecidas por el Gobierno Nacional en materia } \\
\text { ambiental; planificar y ejecutar proyectos de preservación, descontaminación } \\
\text { ó recuperación de los recursos naturales renovables afectados; y velar por el } \\
\text { uso y aprovechamiento adecuado de los recursos naturales y el medio } \\
\text { ambiente dentro del territorio de su jurisdicción, con el fin de mejorar la } \\
\text { calidad de vida de sus habitantes y contribuir al desarrollo sostenible. } \\
\text { http://www.car.gov.co/publicaciones.aspx?cat_id }=81\end{array}$ \\
\hline & \multirow{4}{*}{ DISTRITALES } & ALCALDÍA MAYOR DE BOGOTÁ & \begin{tabular}{|l|} 
La Secretaría General del D.C. asiste al Alcalde Mayor en el \\
ejercicio de sus atribuciones constitucionales y legales, formula \\
políticas para el fortalecimiento de la función administrativa y la \\
articulación de las entidades distritales a través del diseño de \\
instrumentos efectivos de coordinación y de gestión, el \\
mejoramiento continuo del servicio al ciudadano, la promoción \\
del desarrollo institucional, la orientación de la gestión jurídica, \\
el liderazgo de la gestión disciplinaria interna y la protección de \\
los recursos documentales con un equipo humano calificado y \\
con vocación de servicio a la \\
comunidad.http://www.gobiernobogota.gov.co/
\end{tabular} & $\begin{array}{l}\text { Garantizar el gobierno Distrital y Local, promover la seguridad y convivencia } \\
\text { de los habitantes de la Ciudad, Garantizar la justicia en los procesos o delitos } \\
\text { que se presentan en lo urbano y Rural del D.C, asuntos politicos, velar por } \\
\text { los derechos Humanos. }\end{array}$ \\
\hline & & $\begin{array}{l}\text { SECRETARIA DE INTEGRACION } \\
\text { SOCIAL }\end{array}$ & \begin{tabular}{|l|} 
La Secretaría Distrital de Integración Social es una entidad del \\
sector central con autonomía administrativa y financiera que \\
tiene por objeto orientar y liderar la formulación y el desarrollo \\
de políticas de promoción, prevención, protección, \\
restablecimiento y garantía de los derechos de los distintos \\
grupos poblacionales, familias y comunidades.
\end{tabular} & \begin{tabular}{|l|} 
Apoyar las poblaciones más vulnerables del distrito Capital. con especial \\
énasis en la prestación de servicios sociales básicos para quienes enfrentan \\
una mayor situación de pobreza y vulnerabilidad. Así como, prestar servicios \\
sociales básicos de atención a aquellos grupos poblacionales que además de \\
sus condiciones de pobreza se encuentran en riesgo social, vulneración \\
manifiesta o en situación de exclusión social. \\
http://wwww.integracionsocial.gov.co/modulos/contenido/default.asp?idmodulo=
\end{tabular} \\
\hline & & $\begin{array}{l}\text { SECRETARIA DISTRITAL DE } \\
\text { AMBIENTE }\end{array}$ & \begin{tabular}{|l} 
La Secretaría Distrital de Ambiente es la entidad encargada, en \\
Bogotá, de orientar y liderar la formulación de políticas \\
ambientales y de aprovechamiento sostenible de los recursos \\
ambientales.
\end{tabular} & $\begin{array}{l}\text { Preservar la diversidad e integridad del ambiente, el manejo y } \\
\text { aprovechamiento sostenible de los recursos naturales distritales y la } \\
\text { conservación del sistema de áreas protegidas, para garantizar una relación } \\
\text { adecuada entre la población y el entorno ambiental y crear las condiciones } \\
\text { que garanticen los derechos fundamentales y colectivos relacionados con el } \\
\text { medio ambiente. (Artículo 2, Decreto } 561 \text { de 2006). }\end{array}$ \\
\hline & & $\begin{array}{l}\text { SECRETARIA DISTRITAL DE } \\
\text { SALUD }\end{array}$ & $\begin{array}{l}\text { Garantizar el derecho a la salud de todas y todos quienes } \\
\text { habitan en Bogotá. }\end{array}$ & $\begin{array}{l}\text { Ejercer acciones de rectoría del sistema de salud, con el fin de satisfacer sus } \\
\text { necesidades individuales y colectivas, a través de un enfoque promocional de } \\
\text { calidad de vida con equidad, integralidad y participación. } \\
\text { www.saludcapital.gov.col }\end{array}$ \\
\hline & \multirow{3}{*}{ LOCALES } & ALCALDIA LOCAL DE SUBA & \begin{tabular}{|l|} 
El Plan de Desarrollo Económico, Social, y de Obras Públicas , \\
2009 - 2012 "Suba reconciliada y positiva: para vivir mejor", \\
busca avanzar en la construcción de una localidad en la que \\
todas y todos vivan mejor, en la que las acciones de gobierno \\
local se dirijan al mejoramiento de las condiciones y la calidad \\
de vida de la ciudadanía urbana y rural, una localidad \\
incluyente, justa y equitativa en la que se reconozcan, \\
garanticen y restablezcan los derechos humanos, \\
fundamentales y colectivos en perspectiva de género.
\end{tabular} & $\begin{array}{l}\text { Una de las responsabilidades es la erradicación gradual de la pobreza. } \\
\text { Desarrollo de acciones integrales para impulsar: calidad y acceso a la } \\
\text { educación, la salud, la cultura, la justicia, la seguridad alimentaria, el agua } \\
\text { potable y el ambiente sano, el desarrollo de alternativas de producción para } \\
\text { actuar sobre todos los factores desencadenantes de pobreza. }\end{array}$ \\
\hline & & HOSPITAL DE SUBA & $\begin{array}{c}\text { Es empresa social del estado que responde a las necesidades } \\
\text { de salud de su población, mediante un modelo de atención y } \\
\text { prestación que garantiza servicios integrales, cálidos y } \\
\text { humanos. }\end{array}$ & $\begin{array}{l}\text { Responder a las necesidades en salud de los usuarios, familia, comunidad y } \\
\text { medio ambiente, fortaleciendo el modelo integral de atención, con el fin de } \\
\text { impactar positivamente los indicadores de salud. } \\
\text { http://wwww.esesuba.gov.co/quienes.php }\end{array}$ \\
\hline & & $\begin{array}{l}\text { EMPRESA PRIVADA: SECTOR } \\
\text { FLORICULTOR }\end{array}$ & \begin{tabular}{|l|} 
La floricultura como actividad agrícola utiliza altos niveles de \\
mano de obra y de capital en relación con la superficie de \\
terreno empleada, por ello se la considera como actividad \\
hortícola o de producción intensiva, que ademas busca un uso \\
permantente del suelo.
\end{tabular} & $\begin{array}{l}\text { La Responsabilidad Social es la capacidad de respuesta que tiene una } \\
\text { empresa o una entidad, frente a los efectos e implicaciones de sus acciones } \\
\text { sobre los diferentes grupos con los que se relaciona. De esta forma las } \\
\text { empresas son socialmente responsables cuando las actividades que realiza } \\
\text { se orientan a la satisfacción de las necesidades y expectativas de sus } \\
\text { miembros, de la sociedad y de quienes se benefician de su actividad } \\
\text { comercial, así como también, al cuidado y preservación del } \\
\text { entorno.http://www.ccre.org.co/upload/2arto3_g.pdf }\end{array}$ \\
\hline
\end{tabular}




\section{Instrumentos y herramientas de gestión ambiental.}

Posterior a la identificación de actores sociales, es necesario plantear una propuesta que se implemente a través de un programa de saneamiento básico alternativo o ecológico donde se integren los elementos de la gestión ambiental como:

La participación comunitaria a través de un programa de educación ambiental que permita a las comunidades adaptarse y apropiarse de los sistemas de sanitarios secos, lo cual garantiza el buen funcionamiento, la sostenibilidad del mismo y la mitigación de los impactos ambientales, así como el mejoramiento de la calidad de vida de las comunidades rurales del País.

Paralelo a esto es necesario el análisis y la planificación del territorio de las zonas rurales con el fin de adaptar el sistema alternativo a variables ambientales como el clima, el suelo, la humedad, la geomorfología, los patrones culturales y el grado corresponsabilidad de las comunidades hacia la implementación del sistema.

Esta propuesta permitirá el fortalecimiento y permanencia de las comunidades campesinas en sus territorios ya que a partir de esta pueden generar gestión empresarial que asegure un ingreso económico adicional a partir de la trasformación de la excreta en un abono orgánico perfectamente comercializable, además permitirá usarlo en sus propios cultivos, rompiendo la dependencia de los grandes comercializadores de agroquímicos que tantos impactos han ocasionado a los suelos y a la economía campesina.

Es una constante que a las comunidades campesinas se les vulneren derechos constituidos en la legislación como son el derecho a una vida digna, a un ambiente sano, a la educación y a la salud entre otros, por la falta de sistemas adecuados de saneamiento básico, la propuesta de implementación de sanitarios secos como sistemas de saneamiento ecológico para zonas rurales garantizaría la protección de 
estos derechos, además de derechos ambientales como la conservación, preservación y uso sostenible de bienes y servicios ambientales.

Esta propuesta además de abordar las problemáticas socio-ambientales de manera holística permite la interdisciplinariedad ya que se debe integrar diferentes perfiles para la consolidación de la misma, requiriendo personas encargadas de las parte técnica, de diseño, social, empresarial y ambiental. Permitiendo así la convergencia desde diferentes disciplinas y así aportar a la gestión ambiental, a la recuperación del ecosistema y a la implementación de instrumentos económicos que aporten hacia un verdadero desarrollo sostenible de las regiones, donde sus principales actores sean el hombre y la naturaleza reivindicando la relación entre ellos.

Teniendo en cuenta los elementos ya mencionados estaríamos dando respuesta a las problemáticas socio-ambientales reales de las zonas rurales, con herramientas de toma de decisiones para la resolución de conflictos ambientales e implementando una verdadera gestión ambiental en el territorio.

Esta investigación demuestra que existen otras alternativas para mejorar condiciones de saneamiento, que han sido probadas mediante diferentes técnicas como se ha demostrado en el recorrido que se ha hecho en este estudio, teniendo en cuenta las experiencias mundiales donde cada cultura se las ha ingeniado para implementar estos sistemas de acuerdo a las condiciones sociales y ambientales del territorio.

Por último esta investigación busca generar espacios de reflexión y discusión para la implementación de baños secos en las regiones rurales, donde no es viable desarrollar las alternativas convencionales, como son los alcantarillados y no es recomendable insistir en los sistemas de pozos sépticos por las graves problemáticas ambientales que esto ocasiona . 


\section{CONCLUSIONES}

\section{Características socio-ambientales del sistema alternativo de saneamiento básico de baños secos en la vereda chorrillos.}

- La implementación de tecnologías alternativas se deben constituir en una alternativa social que permitan soluciones para los conflictos generados por el desarrollo desigual en las zonas rurales del país.

- La implementación de los sanitarios secos deben contar con la apropiación y organización de las comunidades a partir de la familia, como eje articulador del proceso.

- Al ser Chorrillos una zona de inundación del Río de Bogotá y contar con un nivel freático alto, la construcción y masificación de sanitarios secos genera impactos positivos en la calidad de vida de los habitantes, y la calidad ambiental del sector, lo cual plantea una relación entre la salud y el ambiente favorable para los habitantes de la comunidad.

- El desarrollo de los grupos sociales debe tener en cuenta el acceso a disfrutar de los servicios básicos como educación, vivienda, salud, nutrición, saneamiento y resaltar la importancia de sus culturas y tradiciones, que deben ser respetadas en el marco de cualquier proyecto o programa.

- La presencia de algunas instituciones en el territorio ha generado malestar al implementar proyectos que quedan inconclusos o que culminan después de una serie de capacitaciones, que pocas veces se ponen en práctica, y que a la larga no dejan herramienta sólidas o programas verdaderos que permitan solucionar las problemáticas de la zonas. Esto hace que las comunidades se sientan utilizadas y que las grandes inversiones que se realizan queden en manos de los contratistas que rinden cuentas de sus proyectos a través de un registro fotográfico, y la recolección de firmas. 
- Este tipo de alternativas aporta a los ciclos naturales ya que permite la reincorporación de nutrientes al mismo y se borra la idea de pensar en desechos o residuos que cambio por subproductos o biosólido.

\section{Los baños secos como alternativa de saneamiento básico para zonas rurales.}

- Este tipo de sistemas se constituyen como propuestas ambientalista y no como propuestas para personas en situaciones vulnerables, como lo demuestran experiencias en otros países.

- Esta propuesta permite la conservación de los ecosistemas y a la vez presenta una alternativa de desarrollo para el país la cual puede aportar a experiencias significativas a nivel mundial.

- Los baños secos se constituyen como sistemas alternativos que pueden ser utilizados para prevenir, mitigar o eliminar la contaminación de los recursos naturales.

- Es importante evaluar los diversos obstáculos que frenen el desarrollo de estas alternativas como los económicos, altos costos de inversión, poca inyección de capital, regulación y normatividad que pueden actuar como barreras a la implementación del mismo, investigación insuficiente que lleven al mal funcionamiento del sistema, y por ultimo falta de oferta de accesorios básico para la implementación de los mismos (tazas separadoras).

- Lo anterior nos lleva a reflexionar sobre la viabilidad de desarrollar un proceso de Auto-gestión con las comunidades, teniendo en cuenta que la mayoría de las familias en especial de la Vereda Chorrillos, no cuentan con los recursos suficientes para masificar dicho sistema, es por esta razón que se hace necesario seguir trabajando en la divulgación del proceso y de esta forma establecer posibles convenios así poder obtener una mayor cobertura sobre la necesidad sanitaria de las poblaciones vulnerables. 


\section{Elementos de gestión ambiental, en las alternativas de saneamiento básico específicamente en baños secos para zonas rurales.}

- Falta de control institucional lo cual degrada los planes de crecimiento y desarrollo para las zonas rurales. Previniendo a las comunidades, perdiendo todo tipo de credibilidad frente a los beneficiarios directos, caso claro y evidente en la vereda Chorrillos.

- Es importante que exista voluntad política para la implementación de programas de saneamiento básico acordes con la realidad económica, ambiental y cultural de las poblaciones que carecen de estos sistemas para garantizar la sostenibilidad de los mismos a lo largo del tiempo.

- Los programas de saneamiento básico alternativos deben asegurar la participación ciudadana en el proceso de toma de decisiones para que estas sean acordes a la realidad de sus necesidades y se convierta en verdaderas alternativas de solución.

- El saneamiento básico de las zonas rurales deben propender por respetar la estructura ecológica de las regiones y asegurar la oferta de bienes y servicios ambientales.

- Es importante hacer divulgación de las experiencias exitosas de la implementación de estos sistemas, que se han desarrollado en diversas regiones del país y así poder masificar el uso de las mismas y no estar sujetos a las tecnologías convencionales que en muchas ocasiones son de difícil acceso.

- Es importante resaltar la participación activa de los líderes comunitarios en las ofertas Institucionales (proyectos especiales), apoyando el desarrollo del proceso con sus conocimientos sobre la situación ambiental y social de la Vereda. 


\section{BIBLIOGRAFIA}

AMARTYA. Sen. Las Distintas Caras De La Pobreza. Article publicat a El País, 30 d'agost del 2000. http://www.noucicle.org/arxiu/caraspobr.html

Agua para todos, agua para la vida, informe de las naciones unidas sobre el desarrollo de los recursos hídricos en el mundo, resumen. Organización (UNESCO), Paris, France, UNESCO-WWAP, 2003.

BOFILL-MALS, Silvia. ClEMENTE-CASARES, Pilar. ALBIÑANA- GIMENEZ, Nestor. MALUQUER DE MOTES, Carlos. HUNDESAGOFA, Ayalkibet. GIRNES LLOP, Rosina. Efectos sobre la salud de la contaminación del agua y alimentos por virus emergentes humanos. Universidad de Barcelona. 2005.

BOLTVINIK. Julio. Amartya Sen Y La Pobreza. Publicado en La Jornada, México, 28 y 29 de octubre de 1998.

http://www.geocities.com/wallstreet/floor/9680/nobel.htm?200931

BONILLA-CASTRO. Elssy. RODRIGUEZ-SEHK. Penélope. Más allá del dilema de los métodos: La investigación ciencias sociales. Grupo editorial norma. Colombia. 1997, segunda edición uniandes 1997. Pág. 220.

El "Estudio Antropológico sobre el uso de Letrinas Ecológicas en el Área Rural Andina" fue desarrollado por la Oficina del Fondo de las Naciones Unidas para la Infancia (UNICEF) en Bolivia, a través de Land and Water Bolivia Ltda., 2008).

ESREY, Steven. GOUGH, Jean. RAPAPORT, Dave. SAWYER, Ron. SIMPSONHEBERT, Mayling. VARGAS, Jorge. Saneamiento ecológico. Agencia Sueca de 
Cooperación Internacional para el Desarrollo/Fundación Friedrich Ebert-México. México. 1999. 101pag.

Evaluación de impacto en el área social. Programa agua potable y saneamiento básico Costa pacífica convenio ALA 92/39. Santiago de Cali, agosto 1998. Pág. 124

FALS, Orlando. Conocimiento y poder popular. Siglo XXI Editores. 1986.

GONZALES. Francisco. Ensayo: En busca de caminos para la comprensión de la problemática ambiental. Pontificia Universidad Javeriana. Bogotá. Colombia.2006

GONZALES. Francisco. Ensayo: Reflexiones acerca de la relación entre los conceptos de: ecosistema, cultura y desarrollo. Pontifica Universidad Javeriana. Bogotá. Colombia. 1999.

GUERRERO María Teresa, TAMISET, Han. MARTINEZ Raúl, HERNANDEZ Yolanda. Diseño y construcción de sanitarios ecológicos secos en áreas rurales. Universidad Autónoma de San Luís Potosí. México. 2006.

HDT 55: TECNOLOGIAS DE BAJO COSTO PARA SISTEMAS DE ALCANTARILLADO, Hojas de investigación técnica CEPIS. Ing. Roberto Mejía; Universidad de Antioquia, Colombia. Setiembre 1993.

Informe de la Comisión Mundial sobre el Medio Ambiente y el Desarrollo. Comisión Brundtland: Nuestro Futuro Común. ONU. 1997

KLIKSBERG, Bernardo. ¿Es posible una economía con rostro humano?

Especial para El Universal Caracas, domingo 20 de abril, 1997. http://www.geocities.com/centrolebret/articulo01.html. 
KLIKSBERG. Bernardo. LA TRASCENDENCIA DEL PREMIO NOBEL PARA AMARTYASEN. Economía y pobreza. Domingo 18 de octubre de 1998 Buenos Aires, Argentina. http://www.clarin.com/suplementos/economico/98-10-18/o02001e.htm

LEFF, Enrique. Saber Ambiental: Sustentabilidad, Racionalidad, Complejidad, Poder. 2004.

LEWIS, W.J. Foster, S.S.D. Drasar B.S. Análisis de la contaminación de las aguas subterráneas por sistemas de saneamiento básico. 1988.

LÓPEZ PARRA. Hiader Jaime. Investigación Cualitativa Y Participativa: Un Enfoque Histórico-Hermenéutico Y Crítico-Social En Psicología $Y$ Educación Ambiental. Universidad Pontificia Bolivariana. Medellín. 2001. 220 pág.

Lozano V, Fabio. Polifonía en desarraigo mayor. Mentalidades religiosas, desplazamiento forzado y violencia socio política en Colombia a fines del s. XX. Tesis doctoral. Capítulo Hermenéutica Activa. Toulouse le Mirail. 2002

MARTINEZ. Piedad Cristina Martínez. El método de estudio de caso. Estrategia metodológica de la investigación científica. Mayo de 2006. http://ciruelo.uninorte.edu.co/pdf/pensamiento_gestion/20/5_El_metodo_de_estudio_de _caso.pdf.

MAX-NEEF, Manfred. ELIZALDE, Antonio. Hopenhayn, Martin. Desarrollo a Escala Humana una opción para el futuro. Development Dialogue. Número especial 1986. Santiago, Chile. http://www.dhf.uu.se/pdffiler/86_especial.pdf 
MONTECINO, Vicente. HECKER, Franck Jonathan. Unidades Sanitarias Secas: una solución económica y ambientalmente sustentable para el saneamiento básico. Cooperativa TERROTORIO SUR. Corporación CETAL.2002-2007.

PERALTA, E. "Ecosan": una nueva alternativa ecológica para el saneamiento en Argentina. 1996.

SAWYER, Tom, GOUGH Jean. ESTER, Steven. RAPAPORT, Dave. Saneamiento ecológico. España 1999.

SAWYER, Tom, ANDERSSON, Ingvar. HILLERS, Astrid. ESREY Steven. Cerrando el ciclo: Saneamiento ecológico para la seguridad alimentaria. Segunda edición. México. 2006.

Secretaria Distrital de Salud. Hospital de Suba. Atención primaria en salud con enfoque familiar y comunitario. Diagnóstico barrial vereda chorrillos. Bogotá. Colombia 2006.

VAN HOOF, Bart. PEREZ, Carlos. GIRALDO, Nicolás. Problemática ambiental y concepto de desarrollo sostenible.2000.

http://www.tierramor.org/permacultura/www.ecohabitar.org/PDF/saneamientoecologico. pdf\%20

http://www. zoomZAP Sanitario Ecológico Seco.mht http://www.laneta.apc.org/bs/ http://Diseño y construcción de sanitarios ecológicos secos en áreas rurales.mht http:// Probico - Sanitarios secos, el futuro del presente o el presente del futuro.mht http://www.col.ops-oms.org/saludambiente/Acueductos/condo2residuales.asp 
ANEXO 1

\section{PREGUNTAS GUIAS DE LA ENTREVISTA GRUPO FOCAL}

1. ¿Hace cuanto vive en la zona rural de la Localidad de Suba?

2. ¿Cómo era el territorio anteriormente?

3. ¿Cuál era la forma convencional para eliminar las excretas?

4. ¿Cuándo se empieza a utilizar el baño?

5. ¿Qué sistemas para verter las aguas negras conoce?

6. ¿Qué ventajas identifica en estos sistemas?

7. ¿Conoce usted los sanitarios secos?

8. ¿Qué ventajas y desventajas tienen los sanitarios secos?

9. ¿Cree usted puedan traer beneficios a las familias rurales la adaptación de este sistema como baños interno en la vivienda?

10. ¿Si tendría la oportunidad de cambiar de sistemas de saneamiento básico lo haría?

11. ¿Considera que los sanitarios secos son una buena alternativa de saneamiento básico para zonas rurales en cualquier parte del país? 


\section{ANEXOS 2}

\section{ENTREVISTA A INFORMANTES CLAVES}

1. ¿En qué área se desempeña en Salud Pública?

2. ¿Hace cuanto nació el proyecto piloto de las Unidades Alternativas de Saneamiento Básico del Hospital de Suba?

3. ¿Cuál fue su objetivo?

4. ¿Hace cuanto está vinculado a este proyecto?

5. ¿Cuál es su papel en este proyecto?

6. ¿Cuáles son las problemáticas socio-ambientales que usted identifica en esta vereda?

7. ¿Cuáles son las ventajas y desventajas de los pozos sépticos?

8. ¿Cuáles son las ventajas y desventajas de los sanitarios secos?

9. Beneficios de los sanitarios secos.

10. ¿Usted considera que los sanitarios secos son una propuesta sostenible para zonas rurales en el país? ¿Por qué? 
ANEXO 3

MATRIZ DE ANALISIS DE DATOS CUALITATIVOS

\begin{tabular}{|c|c|c|c|}
\hline CATEGORIAS DE ANÁLISIS & PERCEPCIÓN INFORMANTES CLAVES & PERCEPCIÓN DE LA COMUNIDAD & OBSERVACION PARTICIPANTE \\
\hline $\begin{array}{l}\text { Percepción de los problemas } \\
\text { socio-ambientales de la zona }\end{array}$ & \begin{tabular}{|l} 
Falta de cubrimiento en sistemas de acueducto y alcantarillado. Contaminación del aire \\
por material particulado debido al estado de las vías internas y a la presencia de malos \\
olores. Contaminación de las aguas freáticas por excretas. Problemas de salud como \\
enfermedades respiratorias, diarreicas y dermatitis en la población especialmente en la \\
infantil.Liderazgo atomizado, falta de empoderamiento de la comunidad en general por \\
resolver sus problemas, habitantes sin definición de proyectos de vida, sin habilidades \\
sociales para la resolución pacifica de conflictos, comunicación pobre, grado de \\
escolaridad baja para los adultos, pobreza. Contaminación del agua superficial por \\
residuos sólidos, vertimientos domésticos con conexiones erradas hacia vallados; \\
contaminación de agua superficial por presencia de pozos sépticos sin condiciones \\
técnicas de construcción y manejo, al igual que posibles filtraciones de agroquimicos de \\
los cultivos de flores cercanos; explotación del recurso hídrico subterraneo sin controles \\
claros de las autoridades ambientales; calidad del aire deteriorada por alto transito de \\
vehiculos sobre vías internas (sin pavimentarr), quemas a cielo abierto; Aumento en la \\
presión sobre el suelo por construcción de viviendas, provocando cambio de uso del \\
suelo pasando de actividades agropecuarias a actividades comerciales, de vivienda o \\
de educación privada; no claridad en la definicion de la autoridad ambiental.
\end{tabular} & \begin{tabular}{|} 
Se presentan malos olores durante el dia y en el verano se \\
sienten aún más cuando el sol calienta, el agua de consumo es \\
mala porque los pozos sépticos la contaminan tambien las aguas \\
grises por ejemplo las de los lavaderos. Hay mucha basura \\
porque el carro no pasa a la hora que debe ser y los niños que \\
habitan tiran basura en el vallado. Además hay mucho polvo y el \\
paso de carros y volquetas empeoran la situación. Los niños \\
juegan en cercanias al vallado y muchos ya se han caido \\
ocasionandoles problemas de salud.
\end{tabular} & $\begin{array}{l}\text { Durante las visitas a la zona de investigación se } \\
\text { evidenciaron diversas problemáticas ambientales y } \\
\text { sociales que van de la mano, se perciben olores } \\
\text { fuertes especialmente en las viviendas cercanas al } \\
\text { vallado. Respecto al vallado, especialmente en el } \\
\text { sector dos se evidencia presencia de residuos } \\
\text { sólidos y vertimientos de aguas grises y negras } \\
\text { sobre este. La población manifiesta sentir en } \\
\text { repetidas ocasiones dolores de cabeza, nauseas, } \\
\text { diarreas y enfermedades respiratorias. En las } \\
\text { epocas de invierno la situación se agudiza ya que } \\
\text { los pozos séptico se rebosan, contaminana los } \\
\text { aljibes y en varias ocasiones las aguas negras } \\
\text { entran a las viviendas. }\end{array}$ \\
\hline $\begin{array}{l}\text { Percepción del sistema de pozos } \\
\text { sépticos }\end{array}$ & $\begin{array}{l}\text { Es una solución rápida al problema de la falta de acueducto pero contaminan las aguas } \\
\text { freáticas y el suelo, costoso para la familia en el momento de hacerles mantenimiento. } \\
\text { No se hace un aprovechamiento de los résiduos, presentan emisiónes de olores, } \\
\text { presencia de vectores y trasmisión de enfermedades. Se realiza un alto aporte de } \\
\text { materia orgánica al suelo que puede ser arrastrado al río por la lluvia. Ventajas: No se } \\
\text { requiere conocimientos tecnicos para su construcción, económicos, requiere bajo } \\
\text { mantenimiento, altos costos en mantenimiento para una familia pobre (Vactor), facil } \\
\text { utilización. } \\
\text { Desventajas: Contaminación de agua subsuperficial, requiere espacio para su } \\
\text { construcción y traslado cuando se satura el pozo, mal olor constante, vida útil de } \\
\text { acuerdo a su capacidad o ausencia de mantenimiento, no se puede utilizar para zonas } \\
\text { altamente desificadas, puede tener problemas de regurgitacion de aguas servidas al } \\
\text { interior de las viviendas, Ausencia de una cultura de mantenimiento del sistema. }\end{array}$ & \begin{tabular}{|c|} 
Se usa el pozo séptico que es un hueco revestido en ladrillo y \\
cemento por eso es que ahora tenemos todo contaminado. \\
"Para mi es más bien una desventaja hay perdida total vuelvo a \\
referirme a la casa en al que vivo allá cuando se rebosa el pozo \\
cuan sube el nivel freático las excretas llenan toda la tubería y \\
entonces es un problema porque el olor sale por los sifones \\
adentro de la casa es grave la situación con eso". El costo para \\
desocuparlo es muy alto el carro que lo hace cobra $\$ 280.000$, de \\
resto no se le hace más tratamiento. Otra desventaja es que los \\
ratones suben por las tuberias y entran a la casa por el lavadero, \\
además en epoca de lluvia el agua que tomamos despues de \\
hervirla sabe mal y tiene como nata esto, es que el agua del \\
pozo se combina con el aljibe.
\end{tabular} & $\begin{array}{l}\text { Lo que se observa es que la vereda Chorrillos es } \\
\text { una zona de inundación por su cercania al Río } \\
\text { Bogotá incluso hay varios humedales que lo rodean, } \\
\text { la construcción de los pozos sépticos es muy } \\
\text { cercano a los pozos de abastecimiento de agua. La } \\
\text { comunidad no cuenta con los recursos para pagar el } \\
\text { vactor que es el carro especial para desocupar estos } \\
\text { pozos, por lo tanto se ven en la obligación de } \\
\text { hacerlo con baldes y desocuparlos directamente en } \\
\text { el vallado, ocasionando los problemas arriba } \\
\text { mencionados. }\end{array}$ \\
\hline
\end{tabular}




\begin{tabular}{|c|c|c|c|}
\hline $\begin{array}{l}\text { Percepción sistema de sanitarios } \\
\text { secos }\end{array}$ & 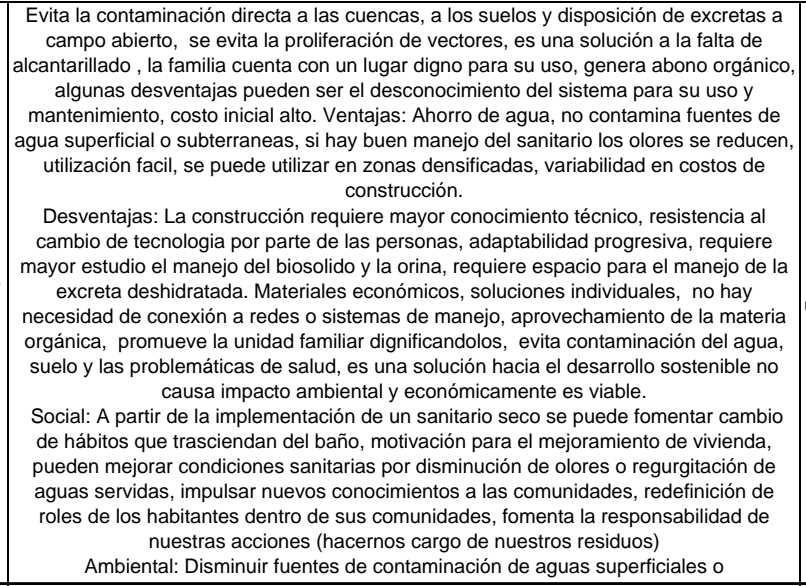 & 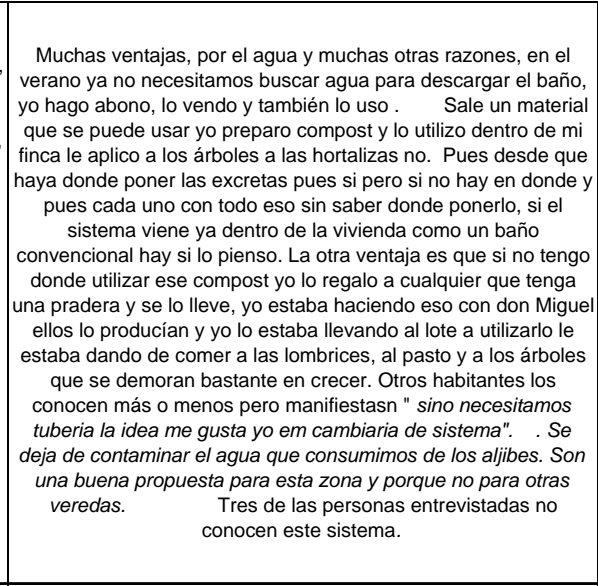 & \begin{tabular}{|l} 
Los sanitarios secos se han convertido en una \\
solucion a las problemática de rebosamiento de los \\
pozos, es un sistema que necesita mantenimiento \\
continuo pero les ha permitido realizar algunas \\
prácticas como la elaboración de abono orgánico, \\
para el caso de dos de las familias decidieron \\
tumbar el sanitario convencional y solo usar el \\
sanitario seco. Baja la carga orgánica del suelo y del \\
agua. Ayuda a la disminución de enfermedades \\
como la diairrea siemprey y cuando el mantenimiento \\
sea el adecuado. Ahorra agua.
\end{tabular} \\
\hline Aceptabilidad cultural & 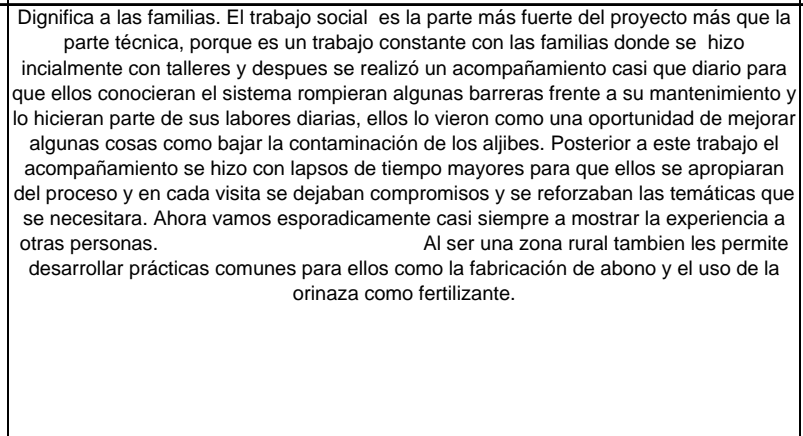 & 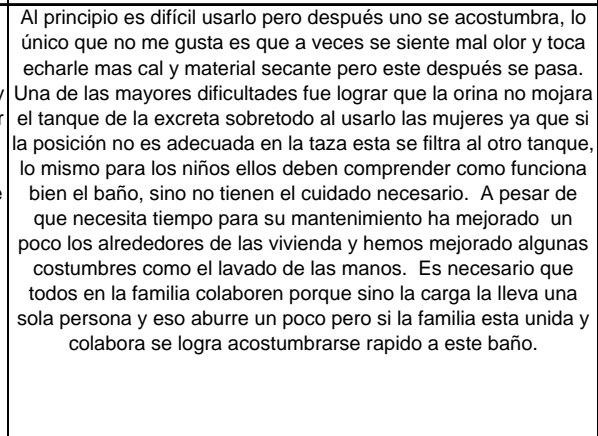 & 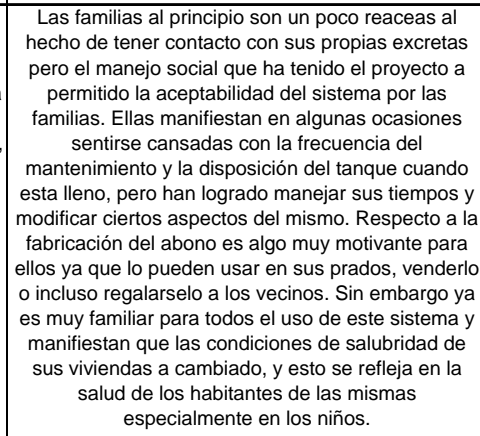 \\
\hline Manejo del sanitario seco & 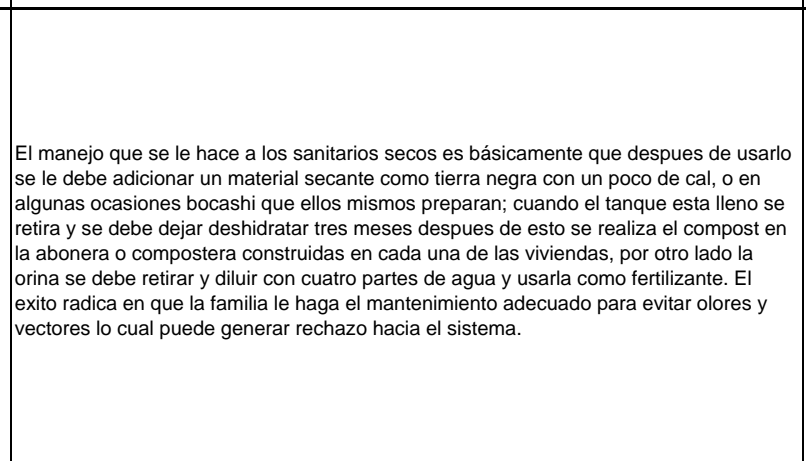 & \begin{tabular}{|l|} 
Bueno nosotros por ejemplo le echamos al tanque ruda, ajo y \\
caléndula maseradito y eso disminuye los olores que se \\
presentan aveces, ademas cuando el tanque esta para ser \\
desocupado lo ponemos en una estiba protegido de la lluvia con \\
un costal encima para que respire y se vaya deshidratando de \\
vez en cuando lo paliamos para que sea más rapido, eso demora \\
como tres meses, de hay lo desocupamos en la compostera y \\
preparamos bocashi nos lo enseño el IlCA se hace una pila con \\
melaza, boñiga fresca, tierra seca, el biosolido (asi se le llama a \\
la excreta deshidratada) y si se puede levadura eso se revuelve \\
bien y se hace una pila se cubre con un costal, la temperatura \\
empieza a aumentar para que mate todos los parásitos aqui nos \\
ha subido hasta 60 grados, esa la tomamos con una termocupla \\
y registramos los datos, ya despues de unos dias se obtiene el \\
abono lo usamos en los potreros o en los árboles en las hortaliza \\
no. Con la orina lo que se hace es que cuando el tanque esta \\
lleno le echamos cuatro partes de agua y lo regamos en los \\
pastos y cultivos.
\end{tabular} & $\begin{array}{l}\text { Durante las observaciones de campo se evidencia } \\
\text { que el manejeje de este sanitario es algo ya familiar } \\
\text { para ellos incluso en algunas familias experimentan } \\
\text { maserando algunas hierbas y prueban si les sirve } \\
\text { para controlar los olores, se ha convertido en una } \\
\text { busqueda constante de nuevas experiencias, en } \\
\text { cuanto a la orina algunos han hechoo parcelas } \\
\text { demostrativas y han tomado nota de los cambios } \\
\text { que observan y manifiestan que con la orinaza el } \\
\text { color y el porte del pasto es más verde y más alto. El } \\
\text { abono se ha convertido para algunos en una fuente } \\
\text { de ingreso ya que lo comercializan con vecinos o } \\
\text { familiares, pero la producción de este no es } \\
\text { constante ya que depende del tiempo en que los } \\
\text { tanques se llenen y se haga el proceso de } \\
\text { compostación. }\end{array}$ \\
\hline
\end{tabular}




\begin{tabular}{|c|c|c|c|}
\hline Aspectos económicos & $\begin{array}{l}\text { Económico: Puede ser una oportunidad de creación de empresas comunitarias para el } \\
\text { manejo de labores de apoyo a la construcción, funcionamiento y mantenimiento de los } \\
\text { sanitarios secos en caso de su masificación; disminución valor de facturación por } \\
\text { consumo de agua por familia. Creación de incentivos económicos para su } \\
\text { implementación por parte del estado. Mayor inversión de la empresa privada. }\end{array}$ & $\begin{array}{l}\text { Se economiza prácticamente toda el agua; uno mismo es una } \\
\text { fábrica de abono para los árboles y para lo pastos y para tener } \\
\text { abono para los productos que saca uno. Otra ventaja es que } \\
\text { necesita una sola inversión no es como un arriendo que toca } \\
\text { estarlo pagando. Con este sistema no pagamos recibos } \\
\text { mensuales por que no necesiutamos conexiones a tuberias de la } \\
\text { empresa privada. }\end{array}$ & $\begin{array}{l}\text { Este sistema permite autonomía en la parte } \\
\text { econónomica ya que no es necesaria la conexión a } \\
\text { redes de alcantarillado lo cual acarrea un costo } \\
\text { mensual por el servicio, además podria incentivar a } \\
\text { la creación de empresas comunitarias que se } \\
\text { encarguen de la recolección y tratamiento del } \\
\text { biosolido de las familias que no lo quieran procesar } \\
\text { En cuanto a la empresa privada es una buena } \\
\text { propuesta por que la fabricación de los accesorios } \\
\text { para estos saños es escasa en el pais y se podria } \\
\text { generar un nuevo mercado si estos sitemas se } \\
\text { masificaran en las regiones con problemáticas } \\
\text { similares, y permitiria crear diseños nuveos con lo } \\
\text { cual se podria entrar a mercados internacionales. }\end{array}$ \\
\hline
\end{tabular}




\section{ANEXO FOTOGRÁFICO 1}

\section{PROBLEMÁTICAS AMBIENTALES}

POZOS O ALJIBES, ABASTECIMIENTO DE AGUA PARA CONSUMO HUMANO.
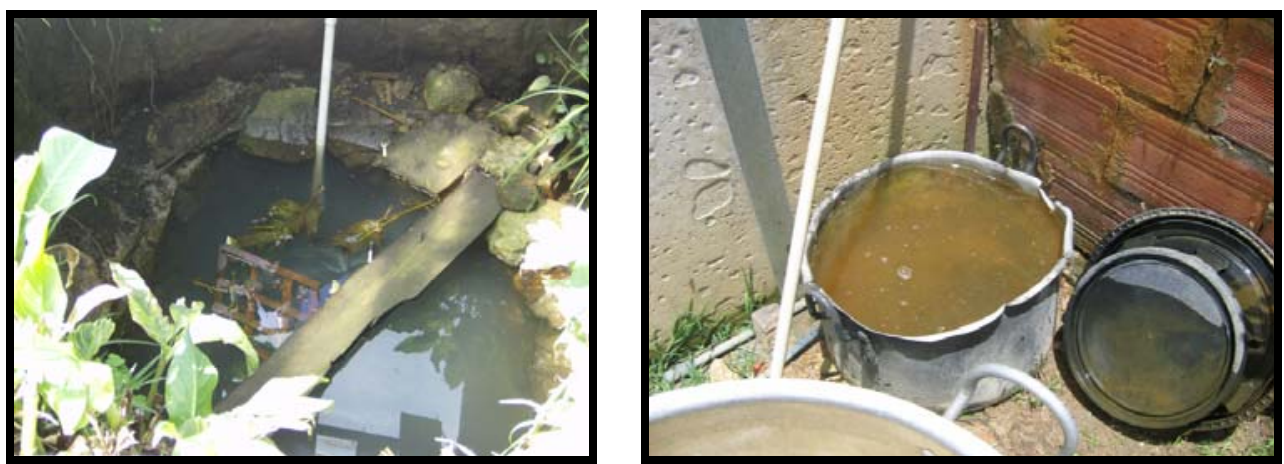

Fuente: Ana Karina Montes. Vereda Chorrillos Sector III. 2008

\section{VALLADO DE FLUJO CONTINÚO}
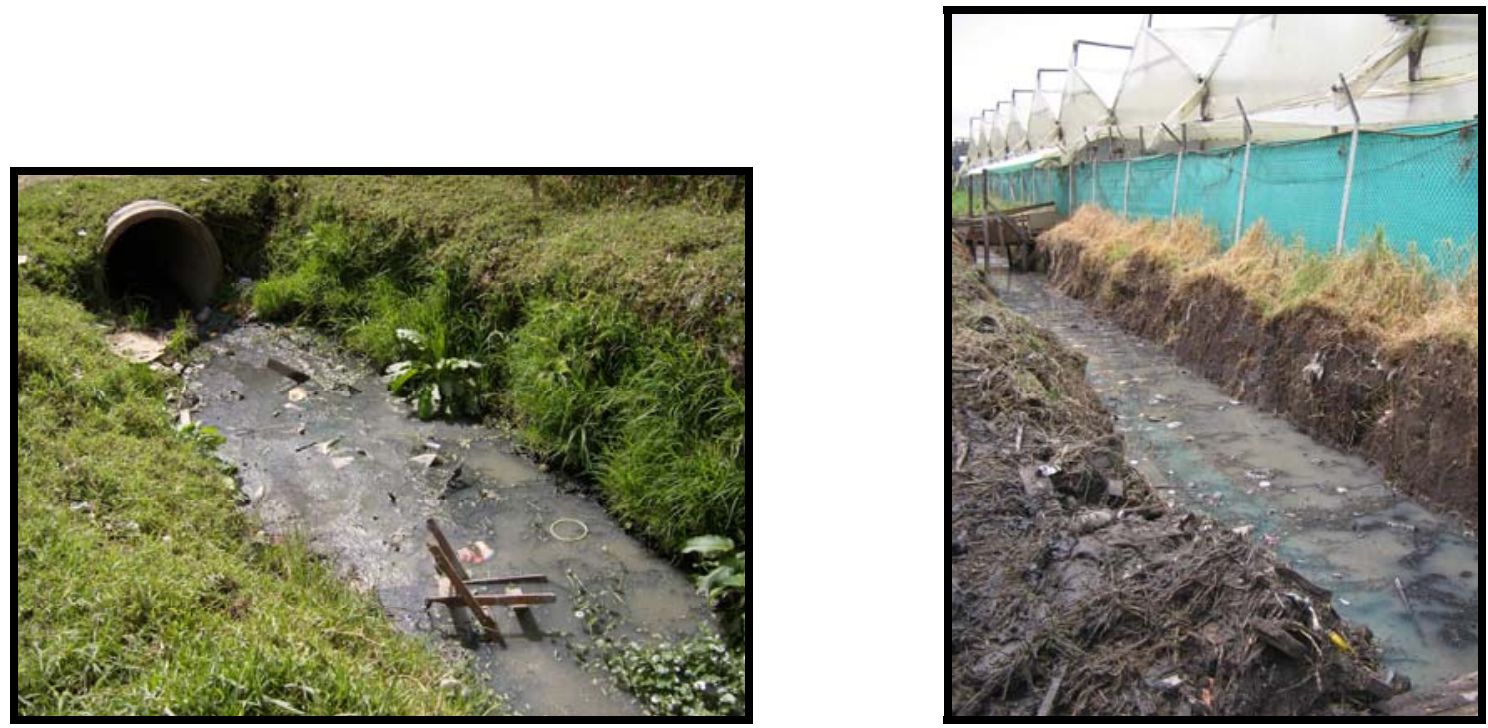

Fuente: Ana Karina Montes. Vereda Chorrillos. Sector II. 2008 
MANEJO INADECUADO DE RESIDUOS SÓLIDOS
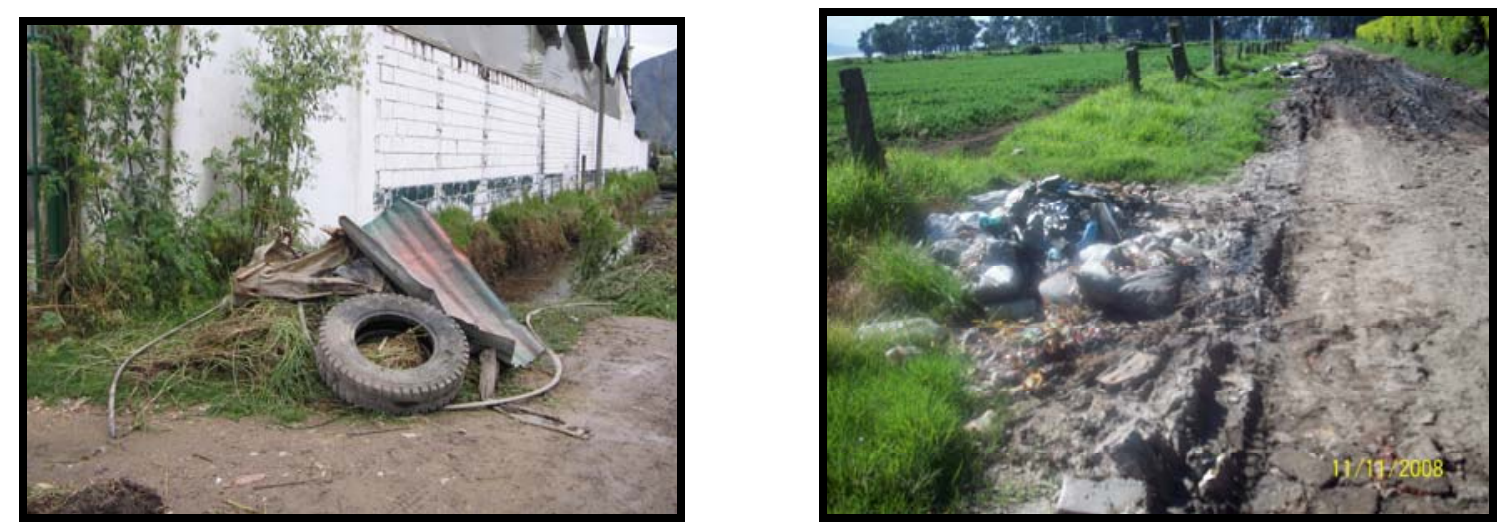

Fuente: Ana Karina Montes. Vereda Chorrillos. Sector I y II. 2008

SISTEMA CONVENCIONAL PARA EL MANEJO DE EXCRETAS. SANITARIO CONECTADO A POZO SÉPTICO
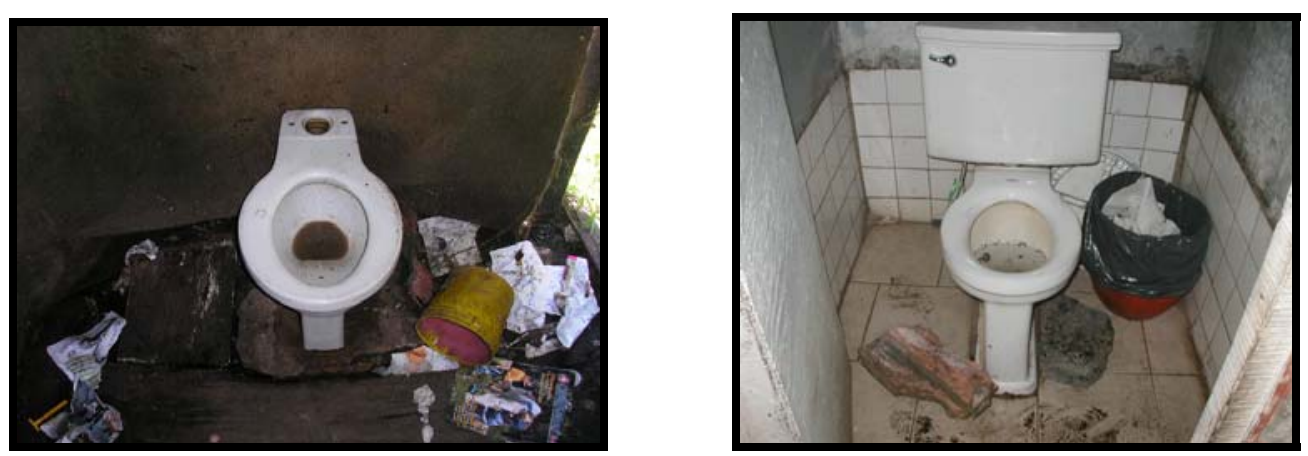

Fuente: Proyecto especial de saneamiento básico. Hospital de Suba. 2007 
ANEXO FOTOGRÁFICO 2

TRABAJO CON GRUPO FOCAL
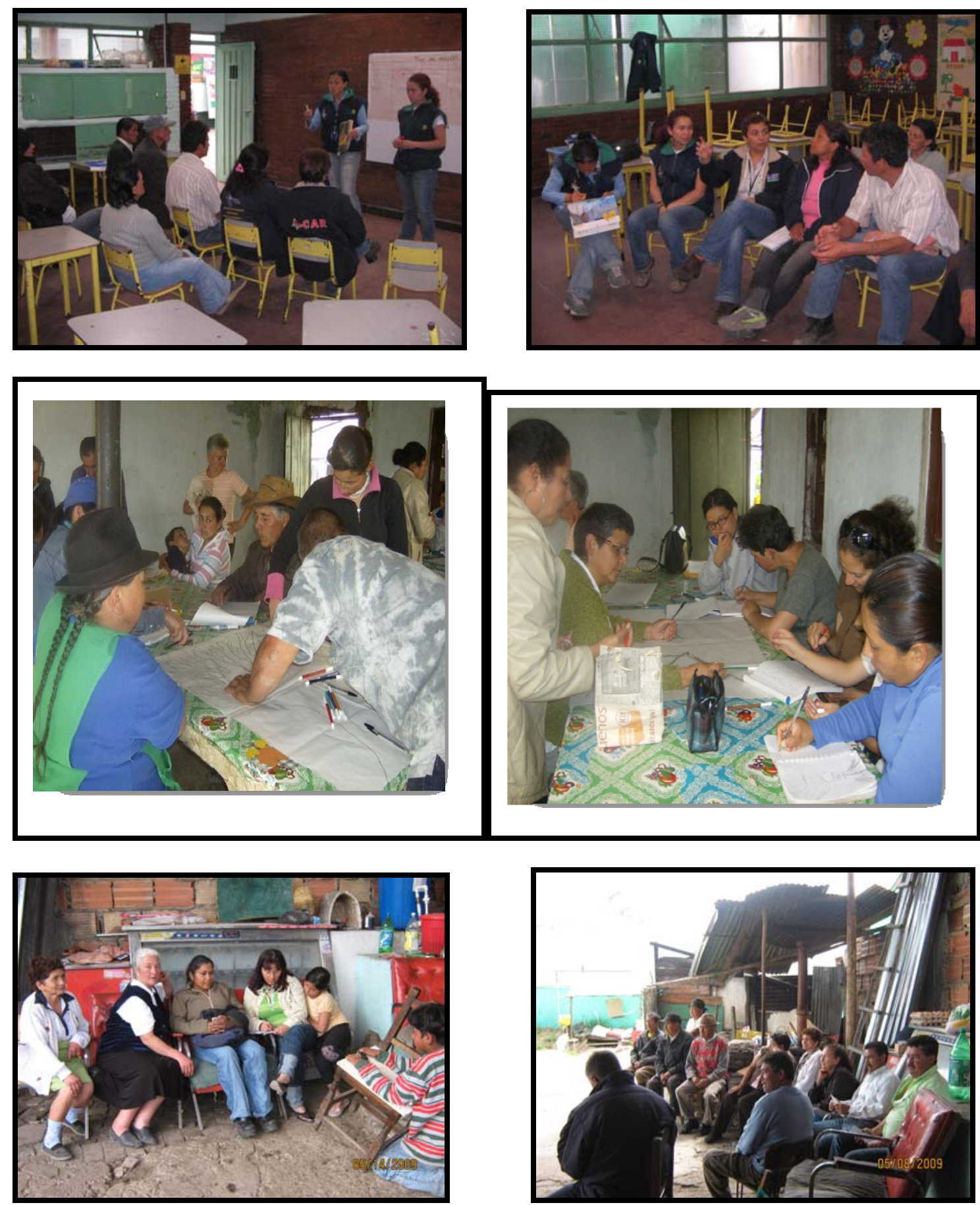

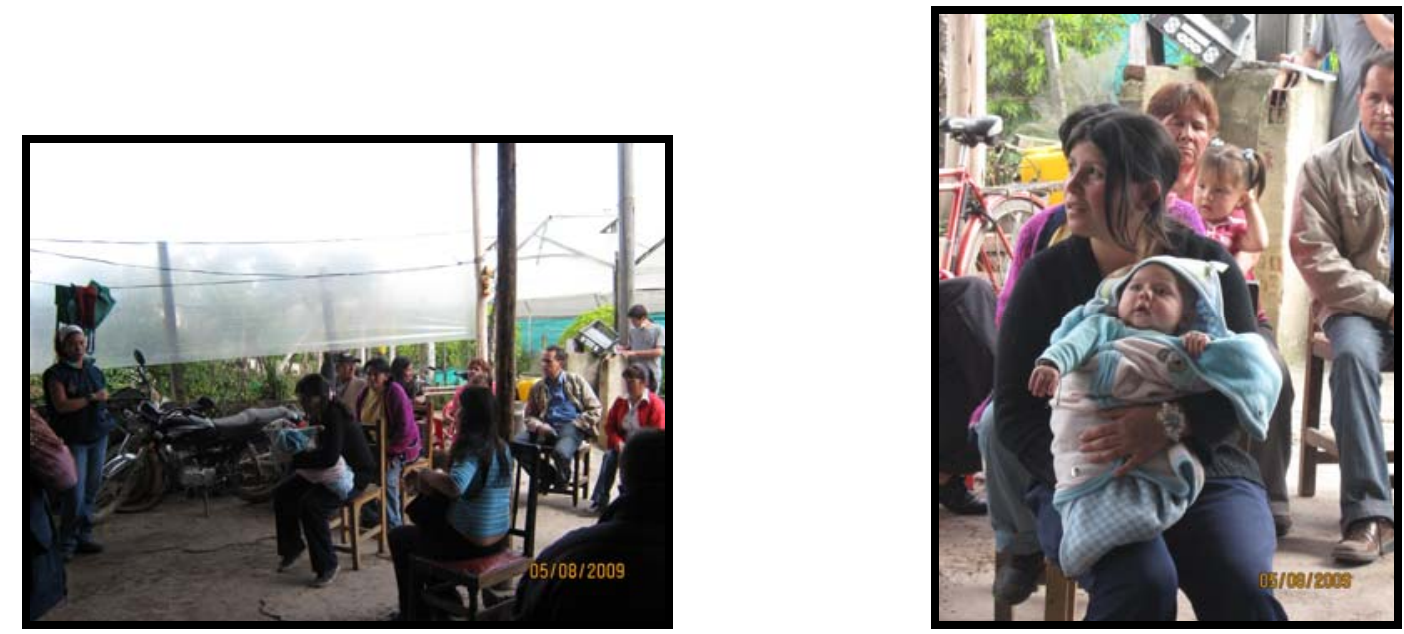

Fuente: Ana Karina Montes. Vereda Chorrillos. 2008-2009

\section{ANEXO FOTOGRAFICO 3}

SANITARIOS SECOS VEREDA CHORRILLOS

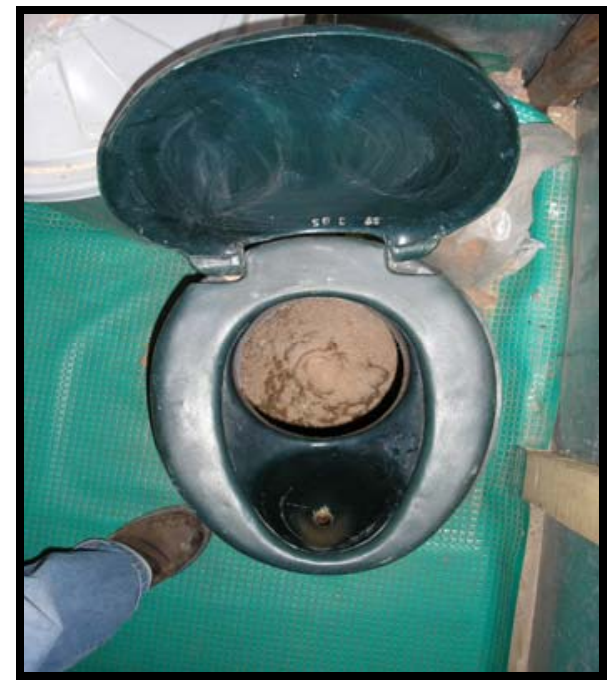

Taza separadora

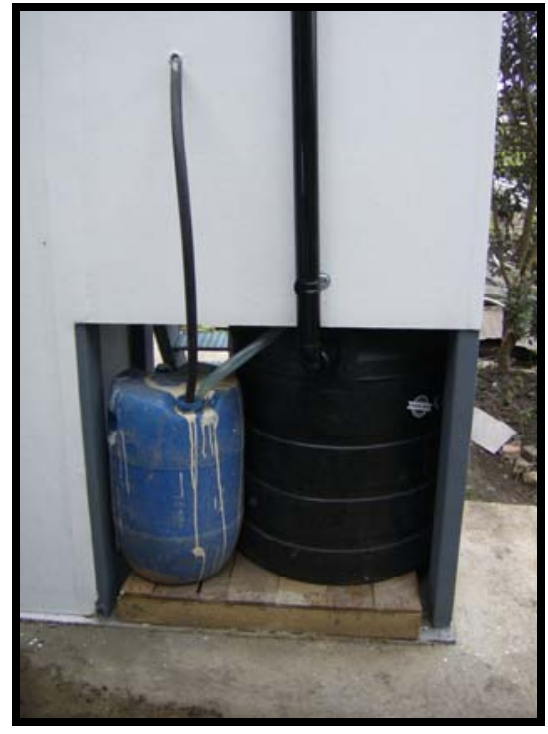

Tanque de orina y excretas con tubo de ventilación. 
UNIDAD ALTERNATIVA DE SANEAMIENTO BÁSICO

PROYECTO PILOTO DEL HOSPITAL DE SUBA
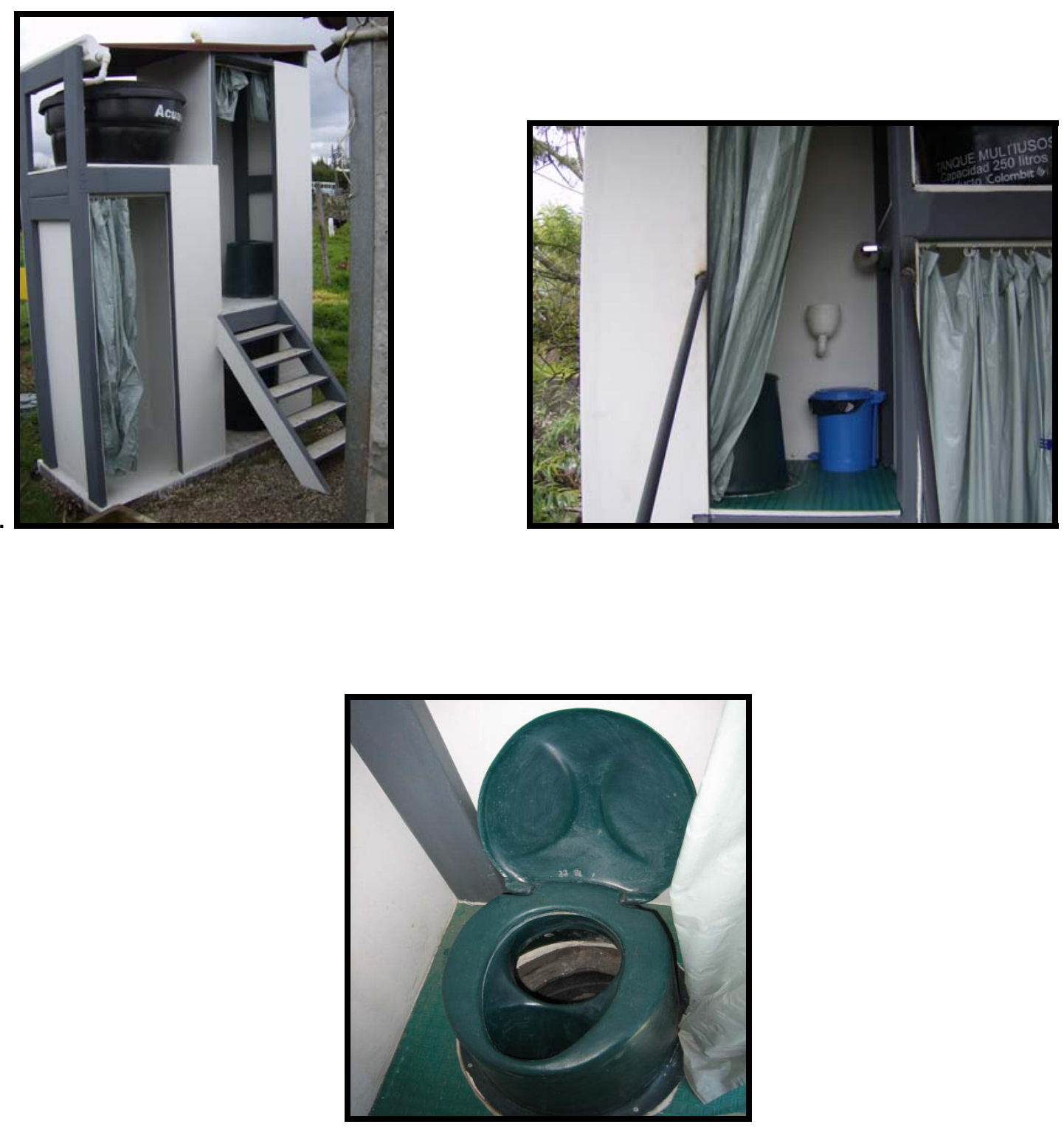

Fuente: Proyecto especial de saneamiento básico. Hospital de Suba. 2007. 


\section{COMPOSTERAS}

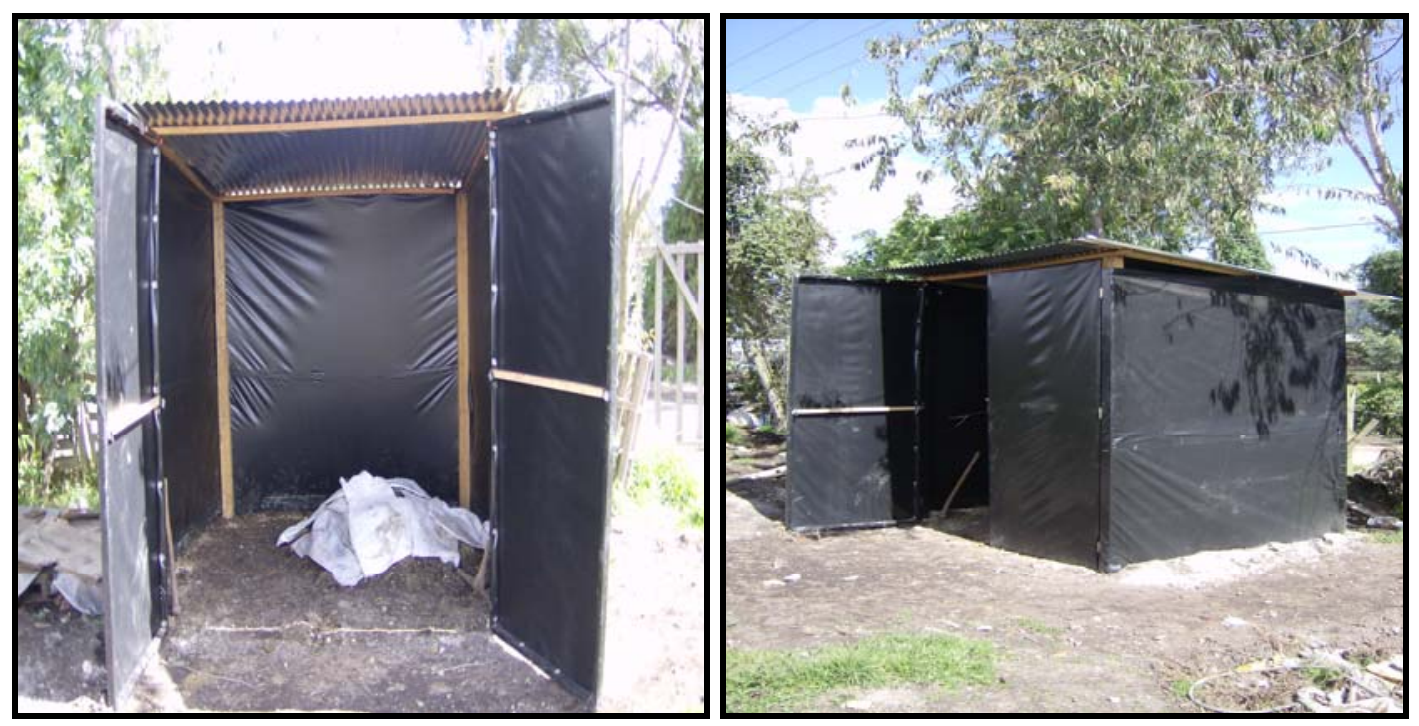

Fuente: Proyecto especial de saneamiento básico. Hospital de Suba. 2007.

MANEJO DEL BIOSOLIDO

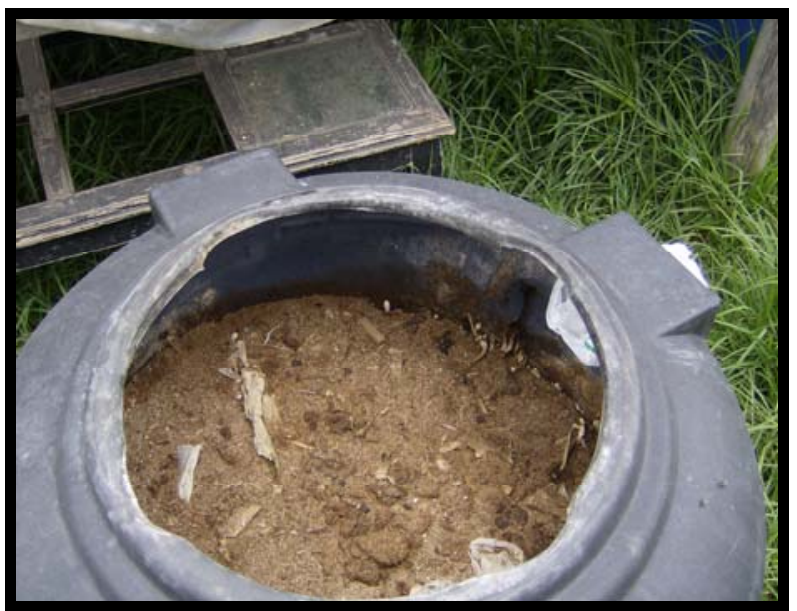

Excreta en deshidratación 

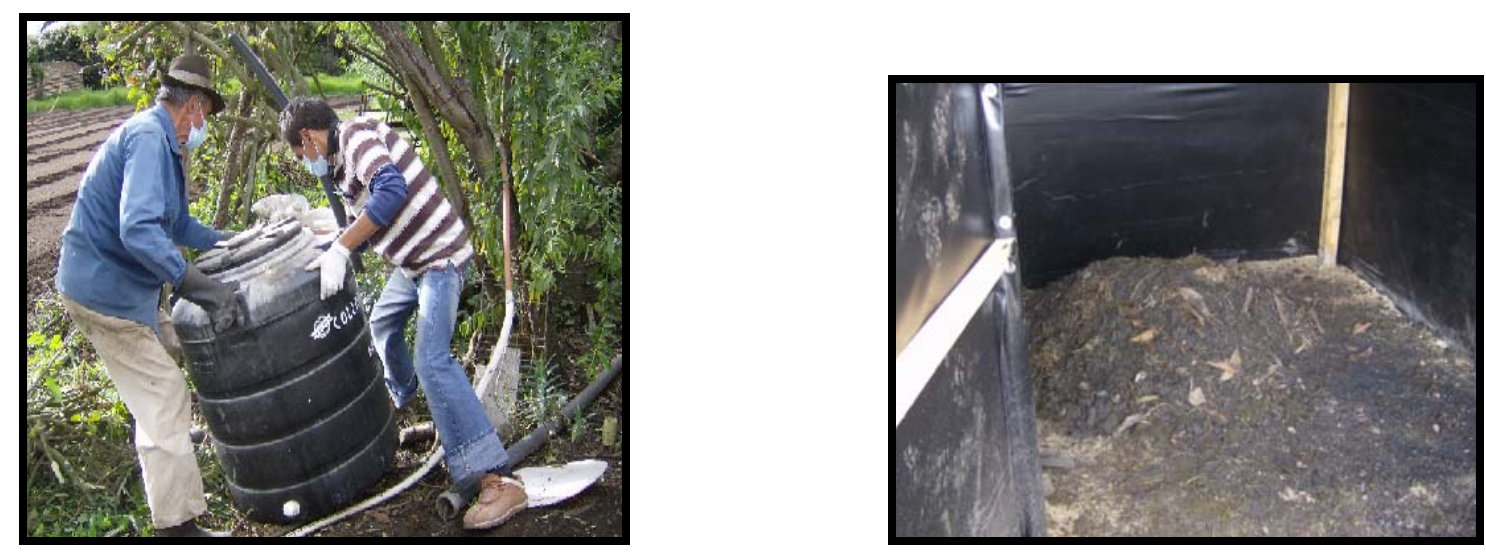

Bocashi

Fuente: Ana Karina Montes. Vereda Chorrillos. 2008

\section{ANEXOS FOTOGRÁFICOS 4}

SANITARIOS SECOS

PERU
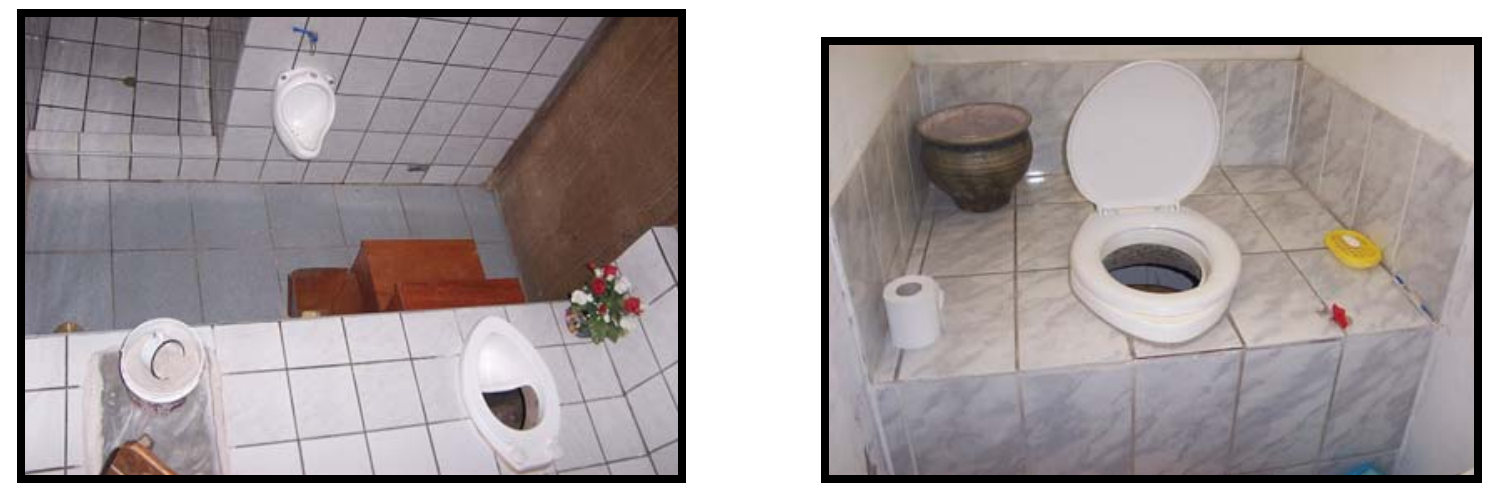


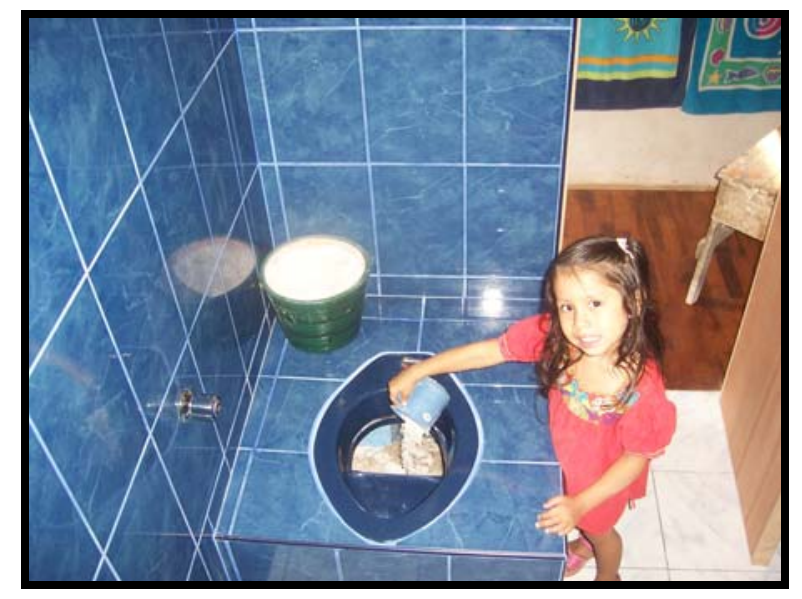

Fuente: Presentación Ecosan. Ponencia Curso Internacional de Saneamiento Básico. 2008 2008.

SANITARIOS SECOS BOLIVIA
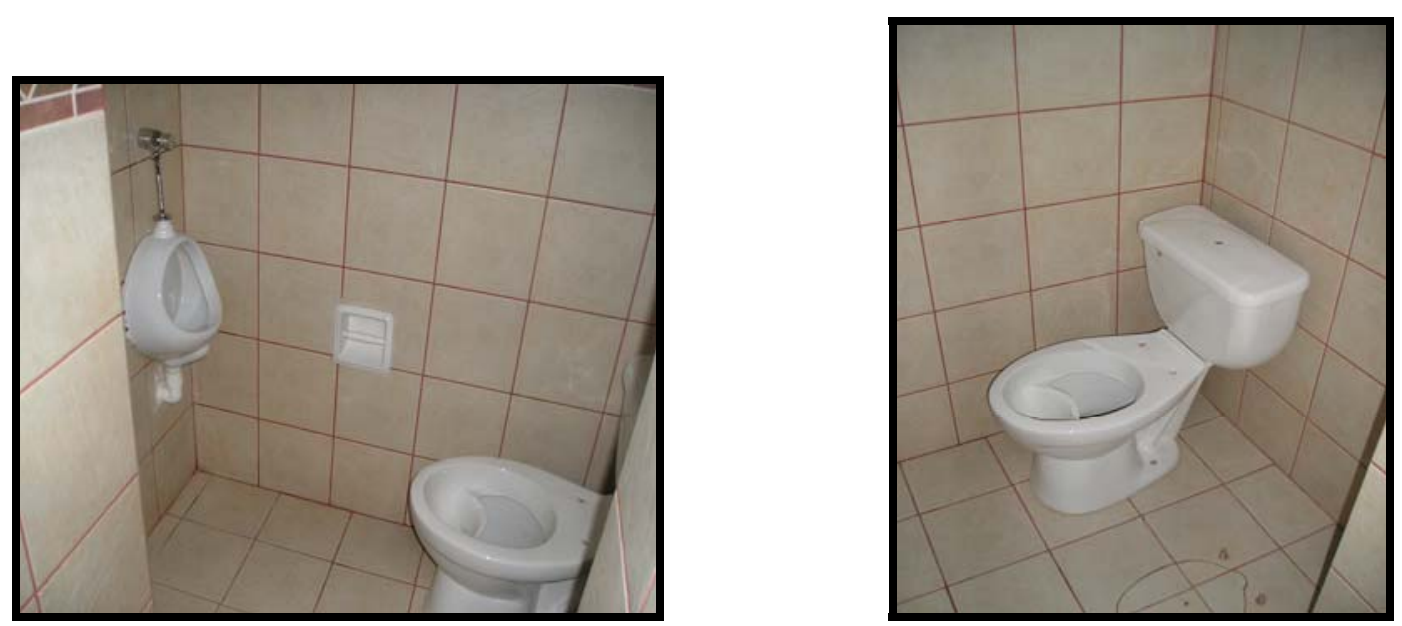


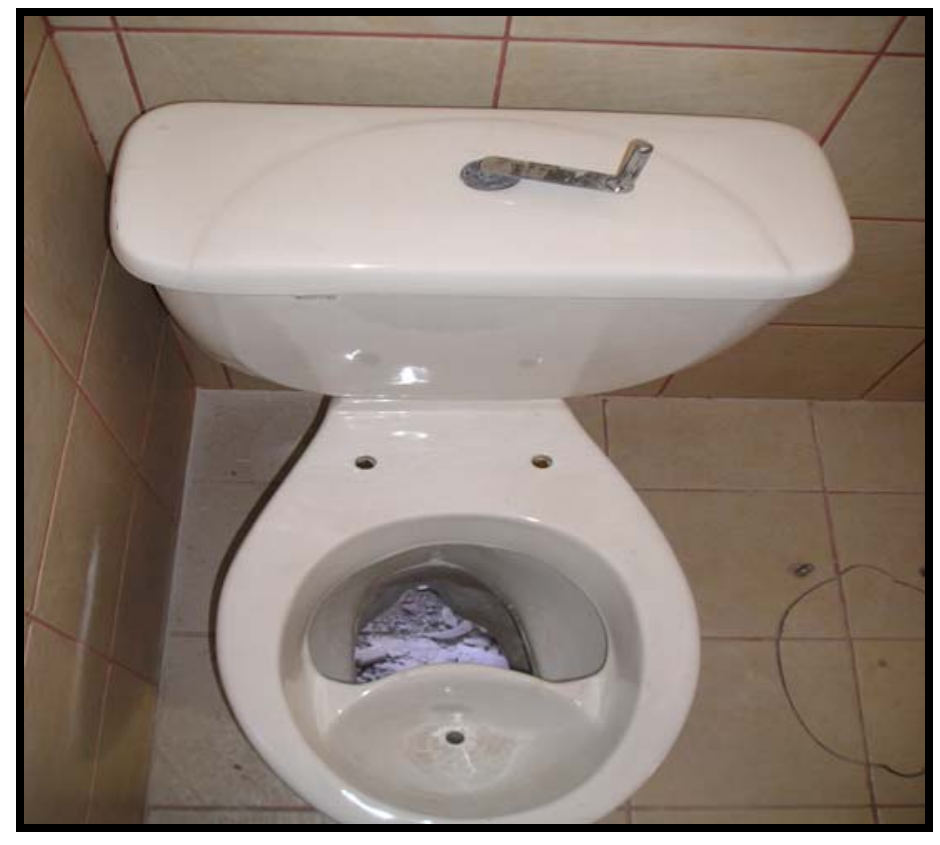

Fuente: Cuerpo de Paz de Bolivia. Ponencia Curso Internacional de Saneamiento Básico. 2008 